Historic, archived document

Do not assume content reflects current scientific knowledge, policies, or practices. 



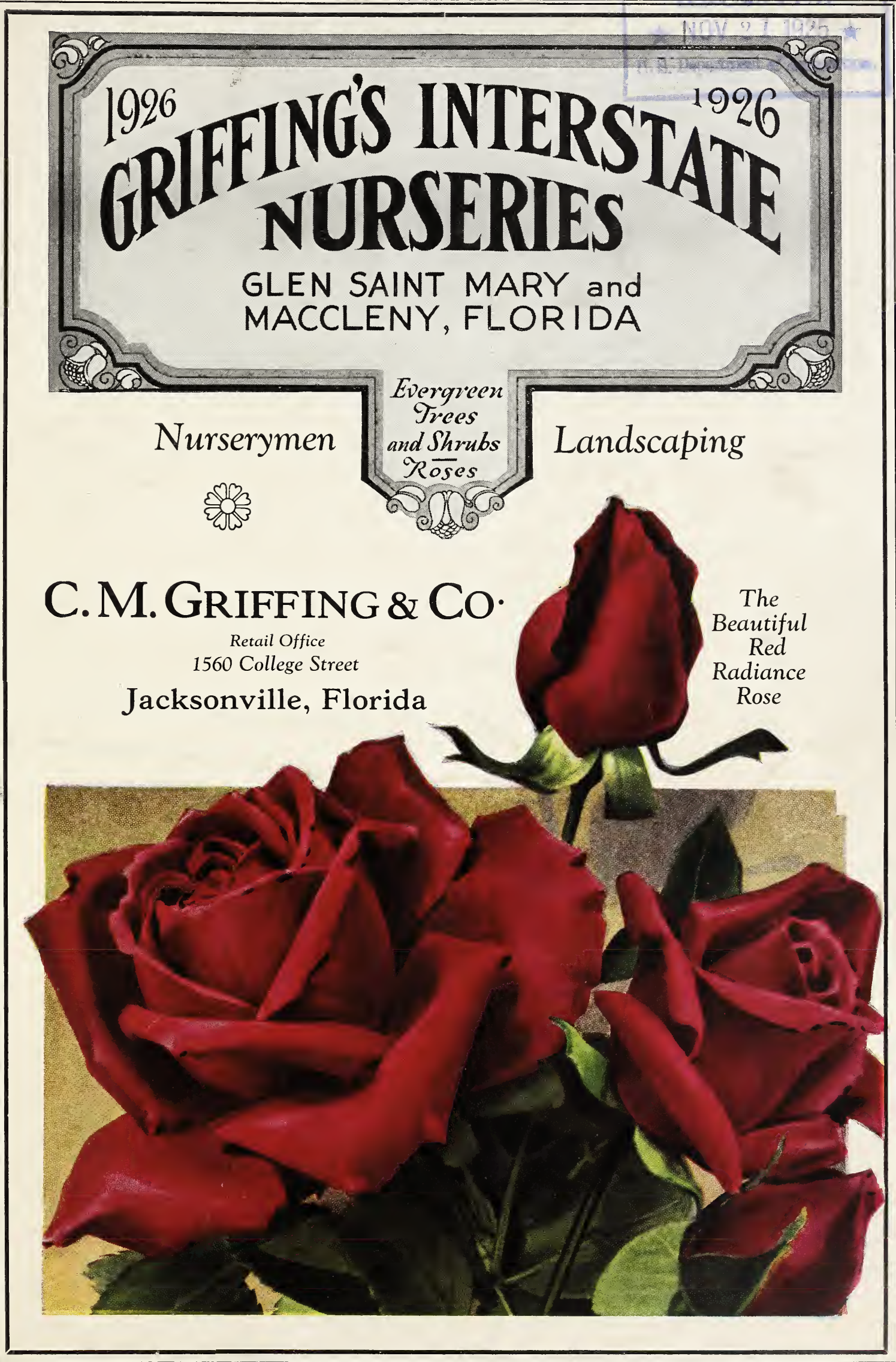



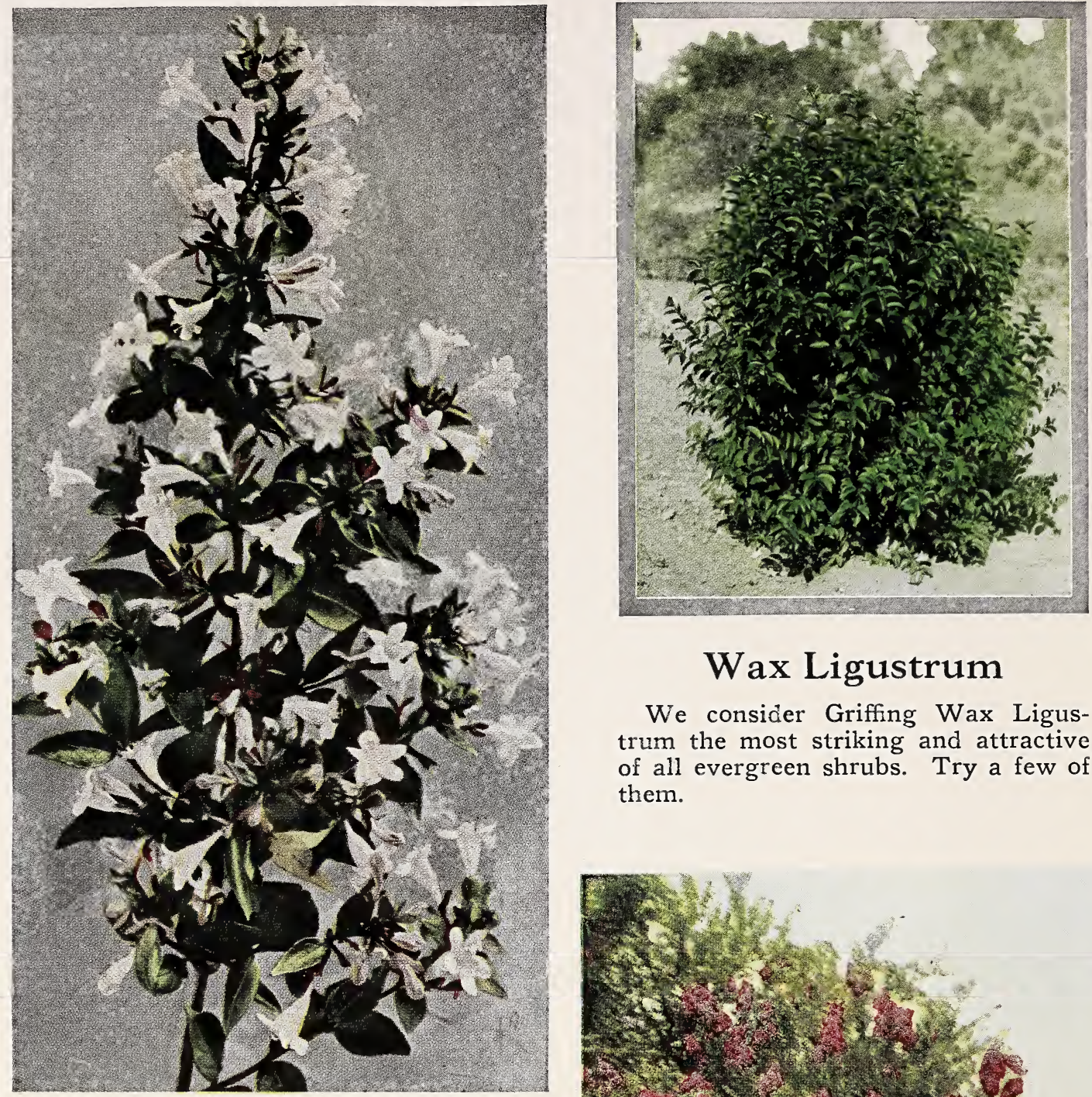

\section{Wax Ligustrum}

We consider Griffing Wax Ligustrum the most striking and attractive of all evergreen shrubs. Try a few of them.

\section{Abelia Grandiflora}

One of the most desirable and beautiful shrubs for the South.

Flowering shrubs are needed to give your grounds a complete, pleasing effect. The profusion of bloom affords you joy and contentment. Include a few in your order. Our list includes the best for the South.

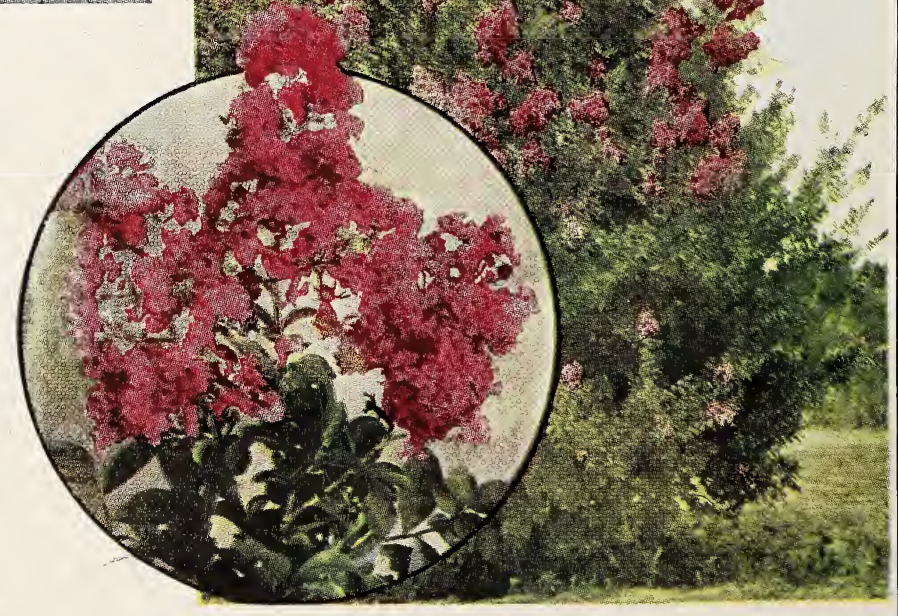

\section{Crape Myrtle}

This popular tree, or shrub, is always admired. Blooms during Spring and Summer. 


\section{Griffing}

HE NAME "GRIFFING" really needs no introduction, for the Griffings have been known throughout the South for over thirty-five years, having in that time furnished their many friends fruit and ornamental stock of the best quality grown. However, in recent years, particularly in the South, the value of Home Ground Beautification has come into prominence and in order to handle the large volume of business where Landscape service is required, we have deemed it necessary to create a Landscape Department. Our desire is that in this way we may more efficiently handle the needs of our patrons.

\section{GRIFFING'S INTERSTATE NURSERIES}

Office: 1560 College St., Jacksonville, Fla.

Nurseries: Glen St. Mary and Macclenny, Fla.

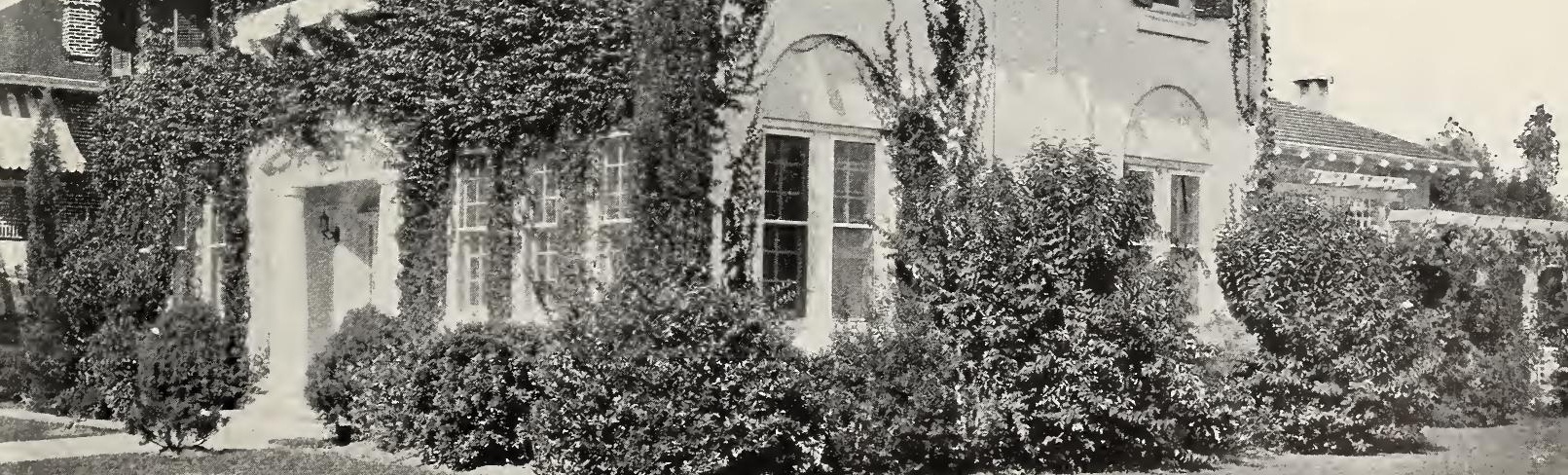




\section{Suggestions About Ordering}

Patrons will oblige us, and avoid possible errors, omissions and misunderstandings by using order blank, and observing the following suggestions and terms of and observing the following suggestions and terms of sale. More
upon request.

Write Plainly. Your signature, postoffice, street or $\mathbf{R}$. F. D. address: name of consignee, destination and route; if a new or small town, give name of county, railroad or river. Designate whether shipment is preferred by exriver. Use separate line for each press, freight,

Indicate size ordered by using either size key letters or by writing size in figures. Extend or carry out prices for each item or group of the same class having a common price.

Many nurseries and dealers buy and sell our stock. Trees or plants sold to nurseries or dealers must be resold by them on their own responsibility. We are responsible only to parties purchasing direct from us.

\section{PRICES}

Prices Are Graduated according to size or age of trees and plants and quantity ordered. Orders for any one class or size of trees having a common price made up of one or more varieties, graduate price applies as follows:

1 to 4 trees, single or each price applies.

5 to 50 trees, ten rate price applies.

50 to 500 trees, hundred rate price applies.

500 or more trees, thousand rate price applies.

This does not, however, apply to long lists of one or two trees each; on such the ten rate should apply.

Prices in this Catalog are for goods properly packed and delivered in good condition to forwarding company, the purchaser assuming all cost and risk of transportation.

Parcel Post Shipments of small sizes will be made for twenty-five per cent advance over list prices.

\section{OUR LIABILITY}

We exercise all possible care to have stock well rooted, well grown, healthy, true to name, properly packed, and shipped according to instructions. It is, however, mutually agreed between the purchaser and ourselves that our liability under the foregoing is limited in amount to original price received. No guarantee expressed or implied that trees will live or grow.

It is to your advantage to order early, as it is almost impossible during the rush of the planting season to fill an order on short notice, without injustice to those who have their orders previously booked. And, while our stock is most complete this year, yet if you do not place have become exhausted. Send us your order as soon as possible, and let us reserve that particular stock you want, for shipment when you are ready to plant. Twentyfive per cent deposit required on orders booked in advance.

\section{REMITTANCES}

To insure safety and prompt acceptance, we ask that remittance be made by Bank Drafts, Express or Post Office Money Orders or through Registered Letters. We do not care to make C. O. D. shipments and will not, unless twenty-five per cent of amount accompanies orders. No orders filled for less than $\$ 2.00$. Our terms are Cash.

\section{SHIPMENTS}

Unless otherwise instructed, orders received during shipping season will be forwarded as soon after receipt as possible Reserve orders will be shipped as soon as convenient after shipping season opens.

Orders Without Shipping Instructions will be shipped as we believe is safest, cheapest and best for our customers interest. Should shipment be ordered by freight, and we find that express rates for the size package are nearly or quite as cheap, we will forward by express.

Shipments at Purchaser's Risk. Our responsibility ceases when we deliver trees to forwarding company. ceases when we deliver trees to forwarding company. will, however, trace, if requested, and use every means at our command to secure prompt delivery, and recovery in case of damage or loss.

\section{SELECTION OF VARIETIES}

Selection of varieties suitable to your locality is of first importance, and can often be more advantageously done
by us than by purchaser. We will gladly aid our patrons in their selections and upon request furnish information as to adapability and desirability of varieties.

\section{SUBSTITUTION}

We desire to follow our customers' wishes in this respect, and have found that they usually wish us to substitute to the best of our judgment in case we are out of any varieties or sizes ordered. We therefore substitute when necessary unless instructed to the contrary.

Inspection. Every shipment we send out will carry a certificate of inspection. Immediately upon making the shipment, we mail to the Plant Board a manifest with the name of the party to whom shipped, giving a list of contents and where stock is grown.

Errors and Omissions. With the best of us, mistakes sometimes occur. If our customers will notify us promptly, we will cheerfully rectify any mistakes that may occur.

Our nurseries are always open to visitors. Inspection will prove our products are the best that experience, good cultivation and favorable conditions can produce.

Our nurseries are located twenty-eight miles west of Jacksonville, Fla., on the Seaboard Airline Railway and the National Highway, one of the best concrete roads in the state, being a main artery of travel connecting with Lake City, Gaineville and Tampa, Fla. It is always a pleasure to show visitors our stock; If notified in advance, we will be pleased to meet you at station or bus line. Our Jacksonville office is located at 1560 College street. When in Jacksonville call to see us. 


\section{Landscaping the Home}

THERE is no place on earth that possesses greater natural advantages for Beautiful Home Grounds than the South; nature has done so much in supplying trees and shrubs that very often man merely selects a spot already shaded and made beautiful with the natural growth on which to build his home. For the pioneer this was most desirable, but, as the country is settled, rural roads laid out on section lines and towns and cities laid out in blocks, there is but little of the natural growth that can be utilized; and here is where the natural advantages of the southern climate and soil, so admirably adapted to the rapid growth and development of trees, shrubbery and palms, make it possible to change (as if by magic) the bare ground into beautiful lawns having the proper setting of trees, shrubs and flowering beds, quicker and better than anywhere else.

The home is the pivot on which life revolves: and deserves to be made as cheerful and attractive as means will permit. Heretofore it was the custom to select such plants or trees as suited our fancy and place them in a haphazard manner about the premises. As is usally the case, we often discover we have unconsciously planted unwisely.

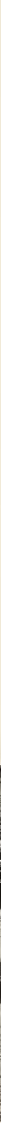




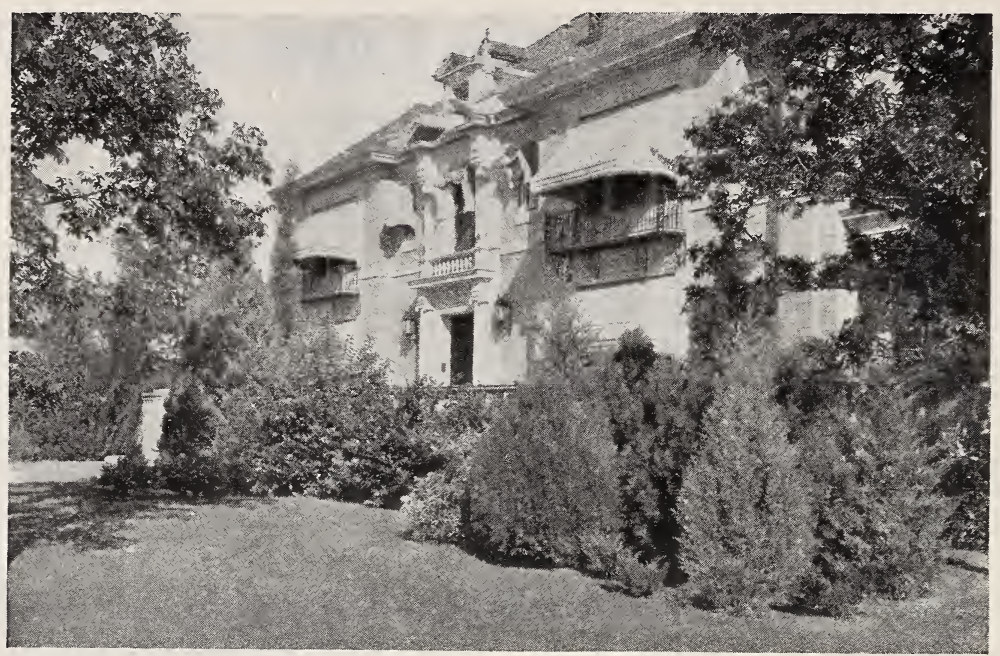

Junipers, Cypresses and Ligustrums Properly Arranged.

\section{The Value of Landscape Planting}

T OOK about you and see how accurately you can judge your neighbors without 1 entering their houses. Outside appearances count. Hundreds see the exterior to one who enters the home. Landscaped home grounds are as essential as furniture and decorations inside and are far more conspicuous and prominent.

Time was when a home owner bought the few plants he loved or happened to know and planted them where he chose. Today, the home grounds are in the primary considerations of home building. Shrubs must be planted generously and properly to be in keeping with good taste.

Beautiful Shrubs increase your property value, make your grounds and house more home-like and a far more desirable place to live. They add distinctiveness and

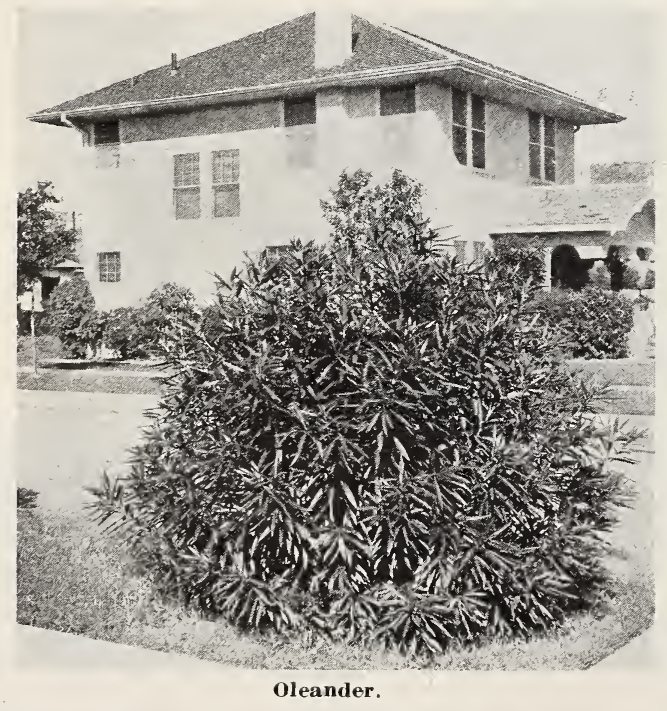
individuality to your property and increase in beauty with the years. The most expensive house is still just a house until the grounds are so planted as to bring out its home qualities and beauties. The smallest cottage or bungalow is not rivalled in beauty by the largest mansion if it is properly planted and the grounds well arranged.

Don't envy a neighbor's landscape display. Resolve to have a better one of your own. We will help you by telling you how and furnishing plants that will give best results. 


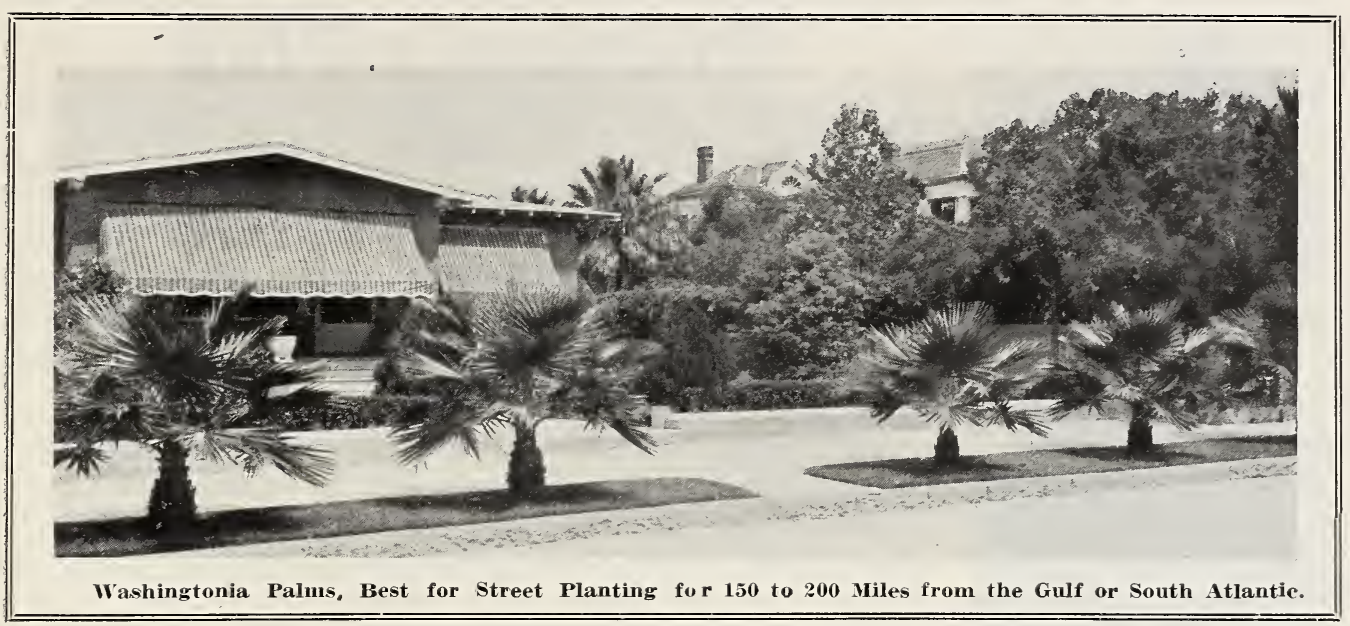

\section{Why Real Estate Dealers and Land Promoters Should Be Interested In Our Landscape Service}

WITH the coming of subdivisions all over the South like so many mushrooms, we are about to be confronted with a problem far greater than we first imagined. These subdivisions are invading almost every nook and corner of this section of the country. Many are, of course, being operated on a well-planned method, while others have no signs of any beauty or home-like atmosphere.

In the past, too many subdivisions have been laid out without thought or consideration to the future beauty of the land and for the interest of the individual home dweller. In too many cases we have actually noticed the existing natural beauty ruthlessly slashed and destroyed through sheer ignorance and greed. As a result the home owner has not received what God really intended he should have for his joy and contentment.

Unless the ones developing these subdivisions take this into consideration, it will only rebound to their discredit and in the end possibly cause financial loss. To entirely overlook this feature of development, will make it more difficult to find purchasers as well as increase the actual cost of selling. With no inducement other than the mere land, it becomes a task to move the property quickly, for it will repel rather than appeal to the one seeking a pleasant place in which to set his or her abode.

Without any doubt whatever it can be safely said that the cheapest way to develop a subdivision is by presenting it in the most attractive manner to the prospective buyer. The developer must keep in mind the essential factors required to make his subdivision attractive and then diligently seek to carry out the idea or plan whereby it may be obtained. The streets are generally first thought of and they should be lined out with trees cr palms. It is said that even one tree sometimes adds hundreds of dollars to the value of the land and yet many times a tree is simply torn down to make way for some supposed improvement. They are often brought down when a little discretion or thought could have preserved them. Such needless destruction is usually associated with real estate developers who do not have the faintest idea of the value of a tree.

Then, we have the parks. No subdivision is a success until it has included parks in the layout of the grounds. Parks are a necessity, they provide the open air and sunlight demanded by children, as well as grown ups, and afford a place for recreation which is essential to health and happiness. But, rather no parks at all than to have them an eyesore for lack of proper care. Unless some arrangement can be made to maintain them in good order, it would be far better to turn the land allotted over to the property owners and give them the chance to beautify.

The streets in a subdivision should be beautified in a like manner. Each street is entitled to as much beautification as the home grounds themselves. The home seeker should feel a sort of pride in selecting his or her home on a street that is already beautified before their arrival. It is absolutely necessary that each street be planted to one kind of tree or palm throughout its entire length. Different streets may have a different variety, but a sense of unity should always be kept in mind, giving a restful and inviting appearance. There is no harmony in a confusion of many varieties of trees. If left to the party who will eventually occupy the house on any lot, there will not be uniformity; this must be done before-hand by the developer.

The question naturally arises, does it pay the developer to put in these additional improvements. Yes, it does. For, although he may be required to spend more in the beginning, he can (and as a rule a reasonable purchasing party, who after all is the one paying for it, is willing to have the improvement) simply pro rate the cost and add it to the sale value of the lot. Furthermore, a subdivision highly developed in this manner will in nearly every case bring a larger and more satisfactory profit to the developer. Another important feature is that if properly managed the entire subdivision can be cared for permanently by the developer by requiring a small fee of each lot owner to keep the property as a whole in an attractive and healthy condition.

Landscaping will, if carried out along the proper lines, enchance the value of any property, but to a far larger degree is the possibility of increasing the value of a subdivision operated and constructed with a vision for the future rather than for the present. 


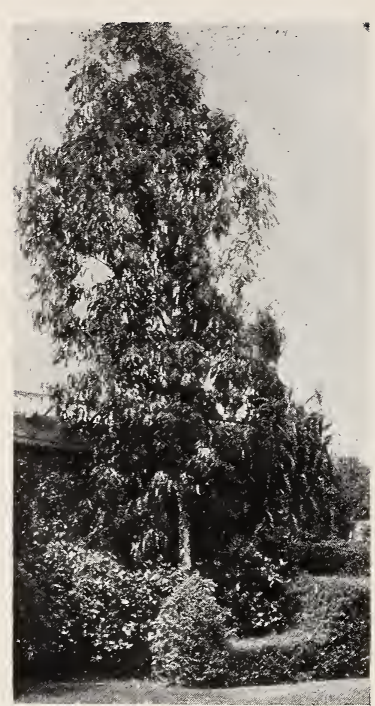

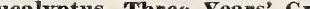

\section{Prepare a Plan}

S THERE are so many difficulties to overcome in the $A$ proper laying out of any grounds regardless of size. we recommend a plan be prepared. With a plan to follow you will be able to eventually give your grounds a finished effect. The plan will enable you to carry out as much, or as little, of the work as desired in the beginning, gradually adding from time to time until eventually you get a well balanced planting.

Look Over Your Grounds. If interested in securing a better arrangement of your home grounds, make up a rough sketch as shown on this page and we will immediately instruct our architect to draw up a plan to fit your surroundings.

First get dimensions of house, garage and other buildings. Then measure length of your lot, distance from property line to back and side of house, and width of the lot. Locate such trees and other permanent plants or structures, draw in walks and drives and give widths. Make a rough penciled sketch as you go and write the measurements in clear figures. Inside the house, write $W$ for windows and $\mathrm{D}$ for doors. Then draw an arrow pointing north and drawing is complete. Send with it snap shot pictures if convenient.

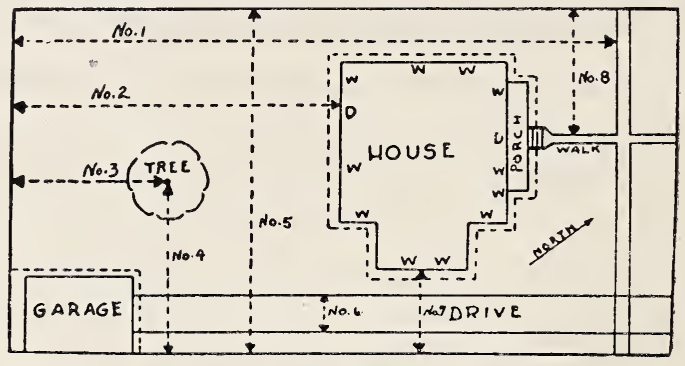

A Simple Method of Measuring Your Grounds for

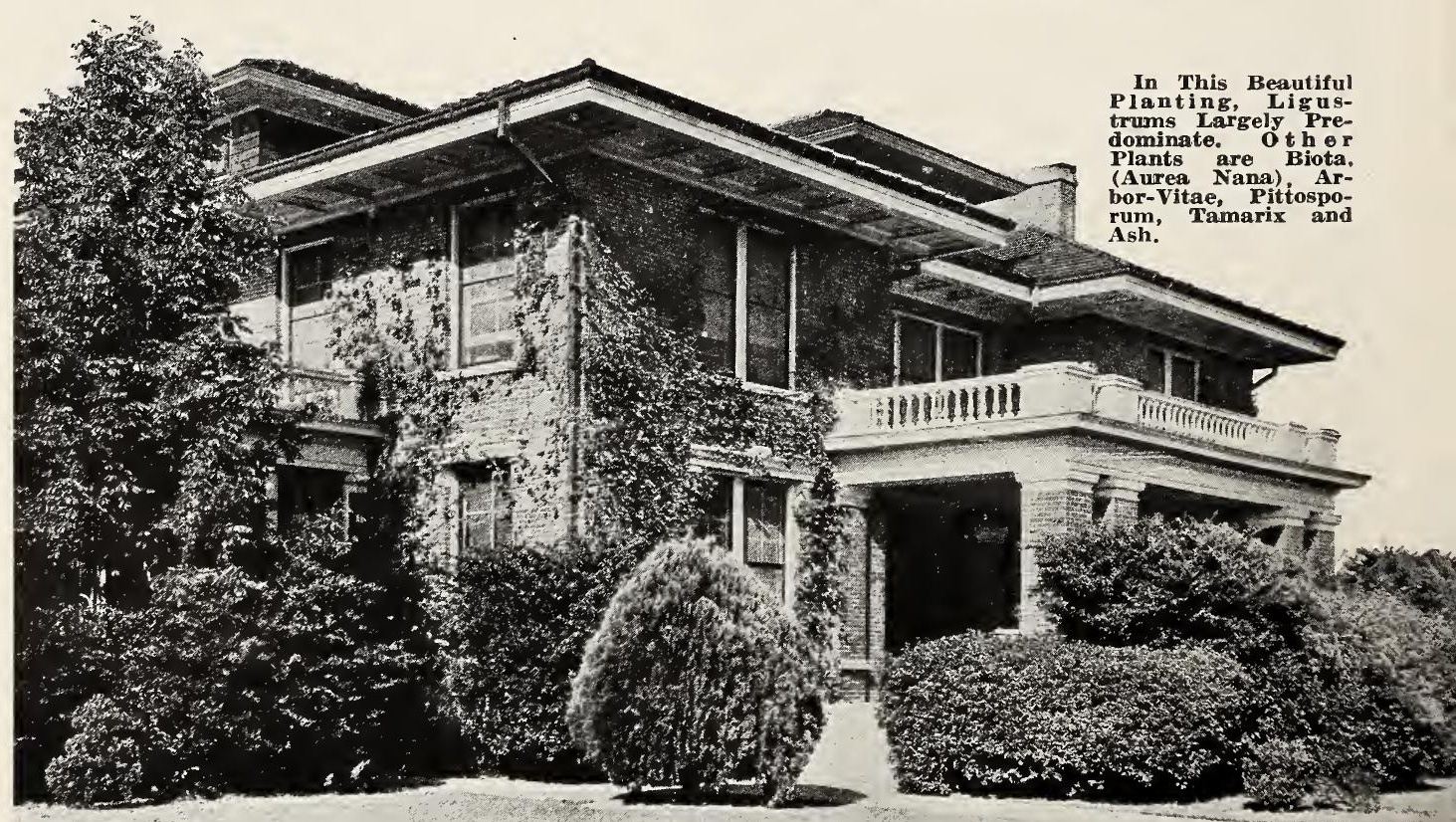




\section{Our Reason for Doing This}

You may wonder why we give all this service free. We offer it because it simplifies the handling of the order. makes ordering easy for the customer, and enables us to handle a large volume of business with less overhead expense, and gives our. customers a free service never before attempted by any Nursery in the South.

While it may be true that we will not book all orders for which we draw sketches, it is reasonable to presume that very few people will take the trouble to ask us to give this service unless they are sincere and fully intend to do the proposed planting.

\section{Large Places and Estates}

Our plan service is offered to all home owners whose lots are the usual size with a frontage up to about 50 feet. Larger lots and big country places should have personal attention. For such places special arrangements will be necessary and advisable, and our landscape department is

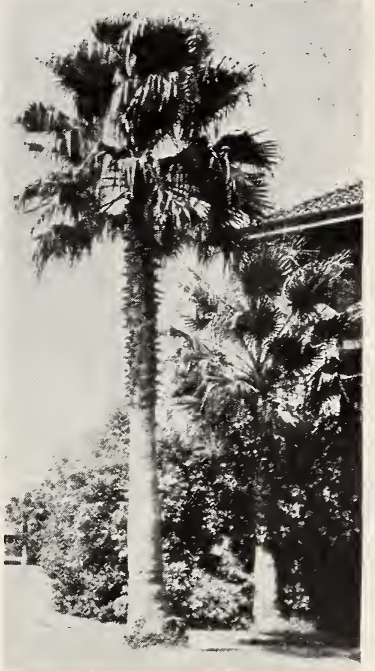

Washingtonia Palms. prepared to render such service at moderate cost.

\section{We Offer Our Service Free}

This is where our Plan Service can assist you to make the right selections and on an economical basis-you paying only for the trees and plants you decide to useand in most cases we will have various sizes to offer so that you may have large or small plants to suit your purse.

\section{Send Plans in Early}

This allows a better chance for attention to your plan.

Don't Delay Your Good Intentions. Many times we are anxious to improve our grounds with ornamental shrubs and plants, only to postpone, with the result that same is overlooked entirely. Today go out and look over your grounds and see if they are what you desire them to be. Send in your rough sketch and leave the rest to us.

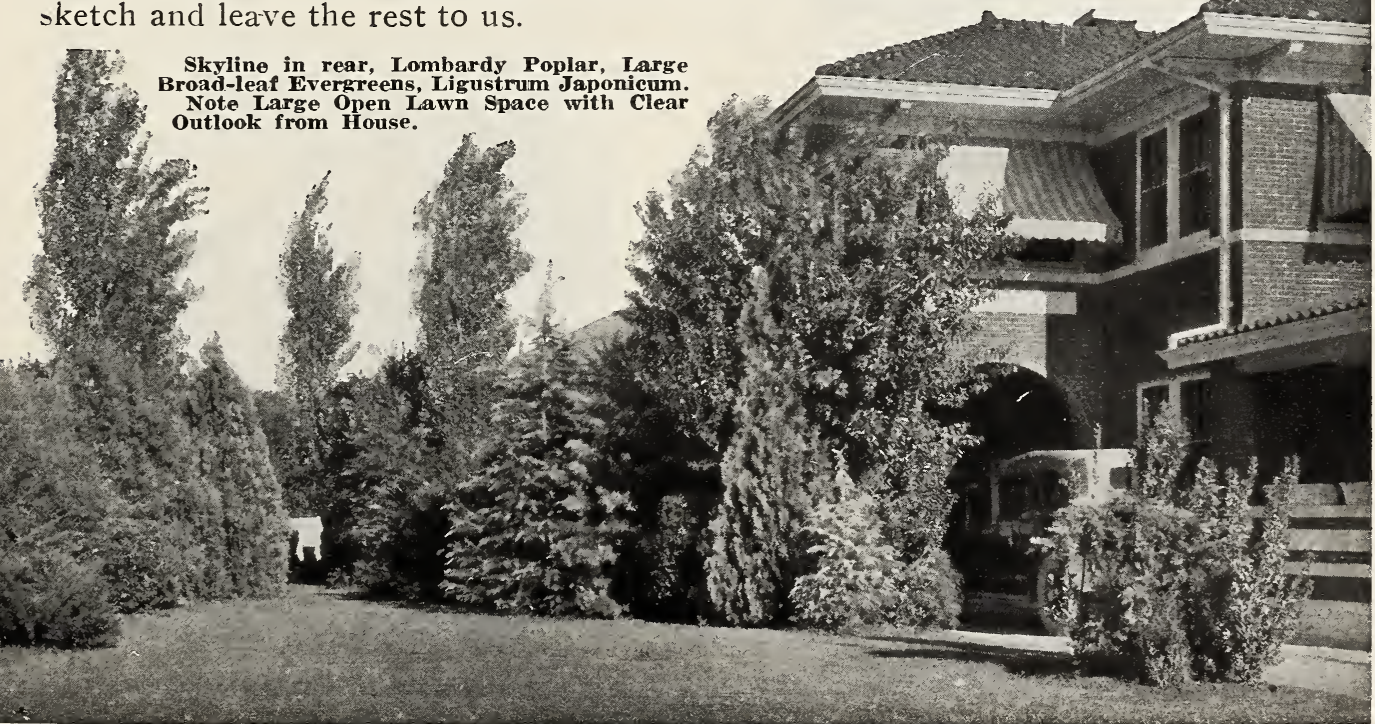




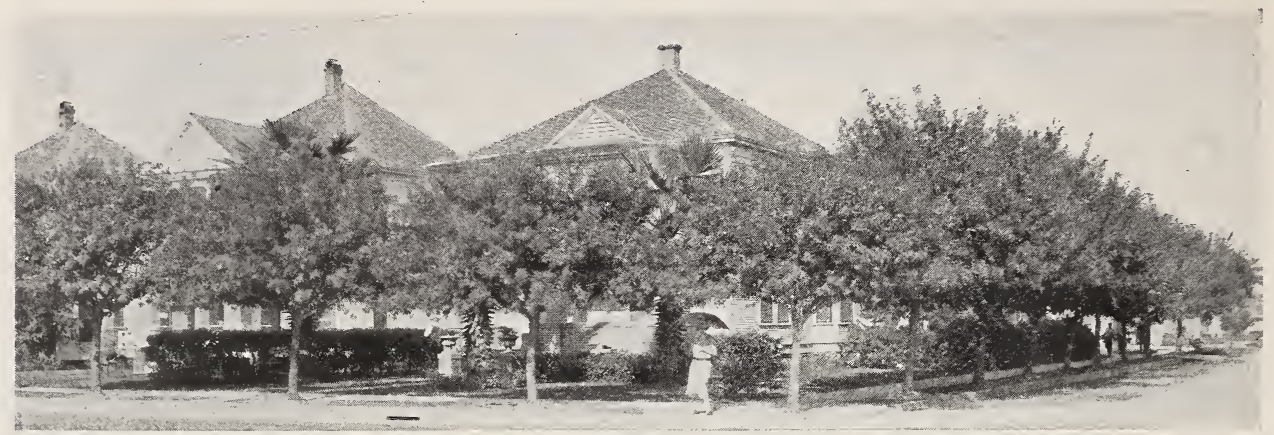

Rio Grande Ash as Shade Trees in a Coast City. "Our Planting."

\section{City, Town or Park Development}

TOO MANY of our southern cities and towns are almost devoid of natural beau-

ty. Every village or city should have a sense of civic pride sufficient to arouse its citizens to the importance of preserving or adding to its beauty. It not only en-

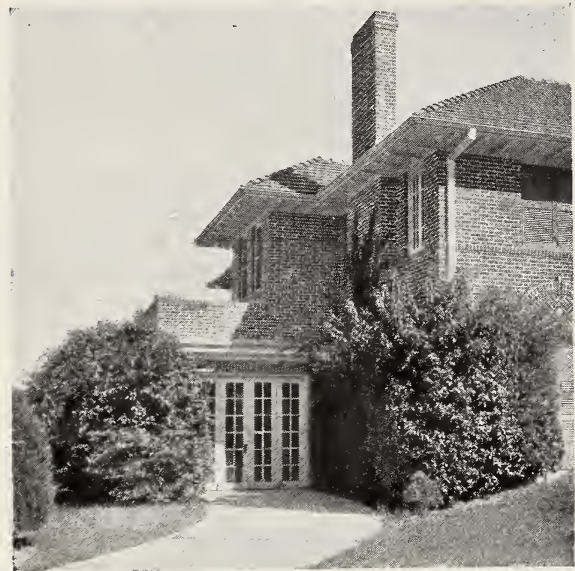

Well Arranged Drive Entrance. Specimen to Left, Sheared Juniperus Virginiana. Shrubs Mostly Ligustrums. ables us to get a little more joy out of the community in which we live, but it has a tremendous impression on the thousands of risitors passing through each year.

The first thought is to provide shade trees and as their need will be continuous, one would naturally suggest the use of long-lived trees but where the immediate need is great, there is also another side to the question. A shortlived tree grows quickly, coming into early usefulness and serves its purpose in a very few years. A long-lived tree usually grows more slowly but it serves its purpose for many more years, soin many cases it is advisable to use both classes of trees in such a way that the longer

lived trees will become useful by the time the shorter lived trees reach their maturity, when they should be removed, leaving the space for further growth of the longer lived trees which should be chiefly of the evergreen class.

Use plenty of Palms. No other tree or plant gives such tropical effect and elegant display as Palms, We highly recommend both Phoenix and Washingtonia for city and park development.

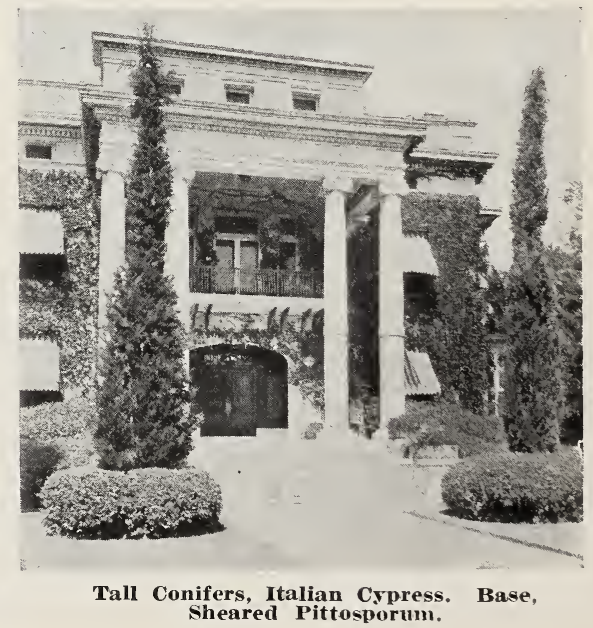




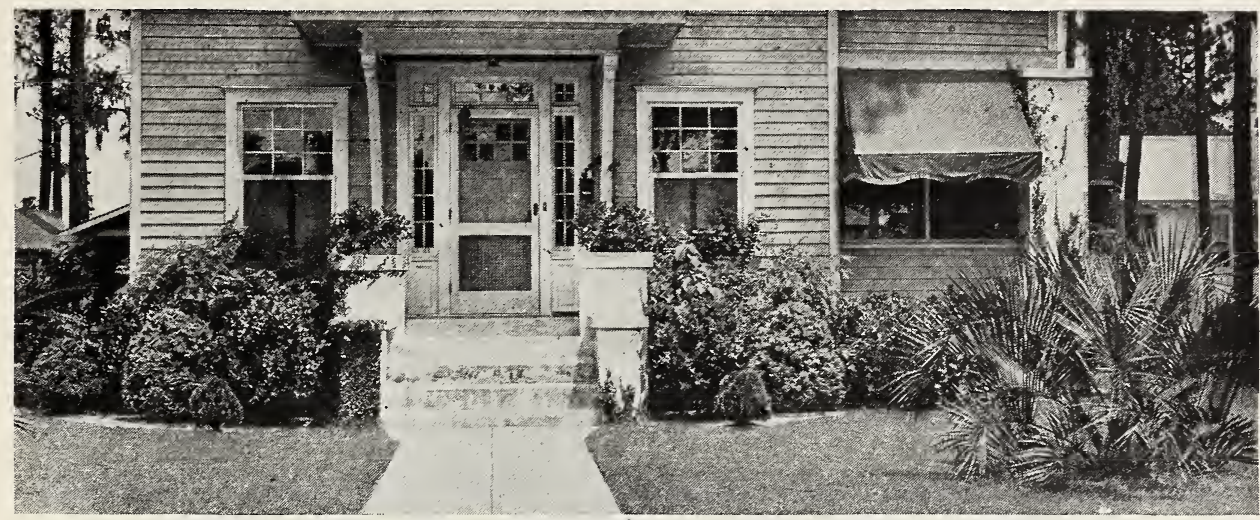

First Planting in Avondale, "Best Sub-division in Jacksonville, Fla." Cocos Australis Palm, Ligustrum, Pittosporum and Conifers are a Part of Foundation Setting. "Our Planting."

\section{Street and Avenue Planting}

Q TREET planting should be uniform in kinds and varieties of trees planted, no $N$ two kinds of shade trees being used on one street. On narrow streets with buildings close to property lines, the taller and more compact growing trees, such as Palms, Eucalyptus, Ligustrum Japonicum, Red Cedar, Southern or Rio Grande Ash, Dogwood, Tallow, and Soap trees should be selected; while on the wider streets the trees of more spreading growth, such as Oaks, Magnolias, Maples, Pecans and Sycamores, may be used more advantageously. Along residence streets where buildings are set close to the pavement, medium size trees with broad spreading tops, such as Camphor, Cherry Laurel, Dogwood, are most excellent. Palms make very attractive street plantings, especially where buildings are close to the sidewalks or pavement, or where shade is not an important factor.

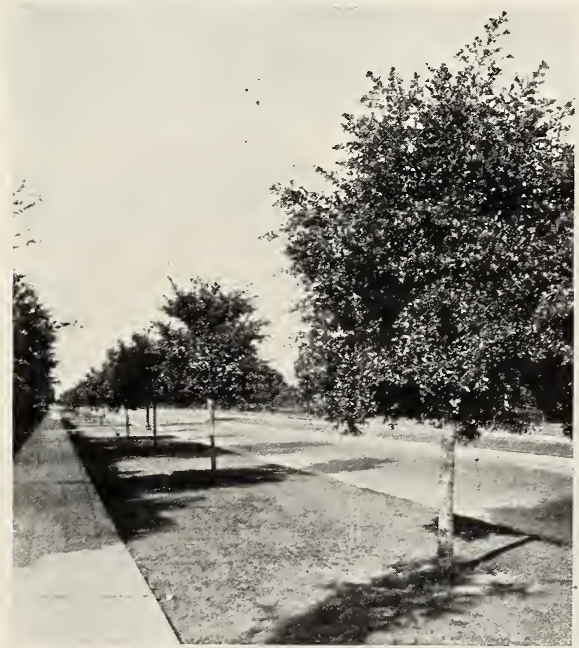

Live Oaks, for Streets That are Wide.

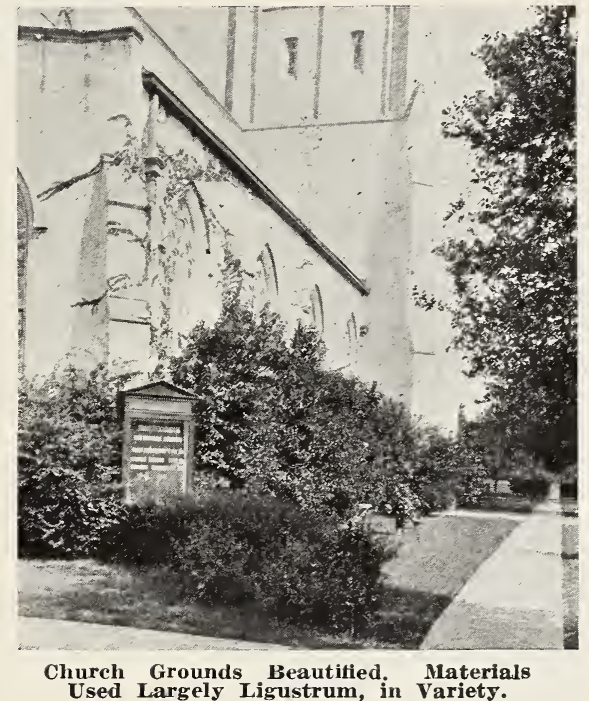

They add a peculiar tropical charm to our southern villages and cities, and especially to our visitors from the snowy North, and should be more seriously considered when planting. Trees should be planted about half way between the sidewalk and curb-line, leaving sufficient space between trees to allow for normal growth and development.

Pecans are among the most desirable for avenue planting or for rear of town or city lots, being as ornamental as any tree that grows, and their annual yield of the best of all nuts makes them more interesting yet. 


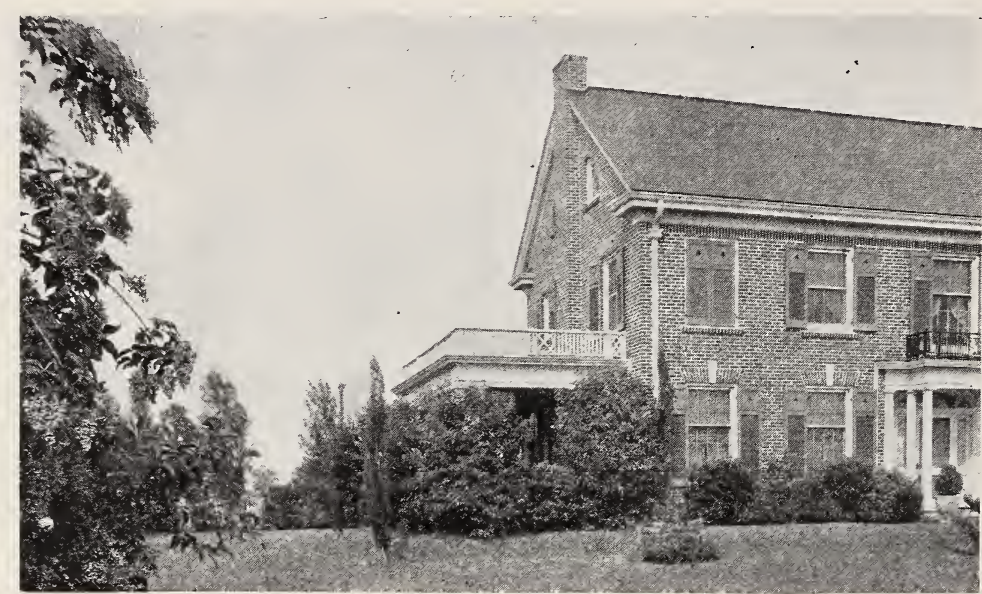

Tall Type of Ligustrum at Corners. Wax Ligustrum and Pittosporum in Front of House. Ligustrum Macrophyllum at Left.

\section{The Importance of a Complete Planting}

W $7 \mathrm{E}$ WISH t.? emphasize the value of having a complete planting done wherever it is pcssible. Every home dweller has the right to plant what he chooses, yet from our long experience in beautifying homes we have found it pays to set all stock as near one time as is convenient. Rather than write us for individual prices on plants, just send us a list of the plants you love best together with an outline of your buildings and grounds, and we will thoroughly examine same and offer you our suggestions. Our service includes not only the supplying of the plants selected but in addition the preparation of plans, specifications and even the laying out and planting of entire work. Ask for full details concerning plans and cost for Professional Services.

\section{Our Service Plan}

With the facilities we have at our command we are safe in stating we can handle your work in a way that will assure satisfying results. You can rely on our service, as we have experienced men in all departments. Professional

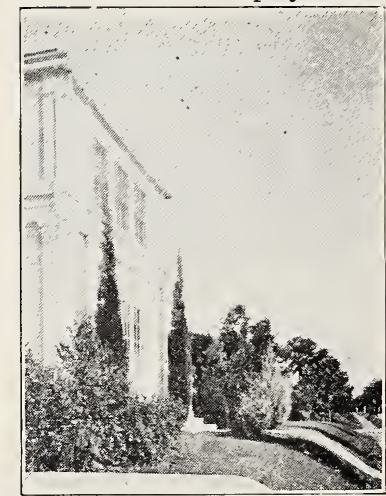

Correct Usage of Tall Conifers. charges for plans and consultation are subject to the extent of improvements to be carried out, covering time consumed in traveling, consultation, inspection, preparation of plans and specifications. After inspection is made an estimate of the cost of entire work will be submitted.

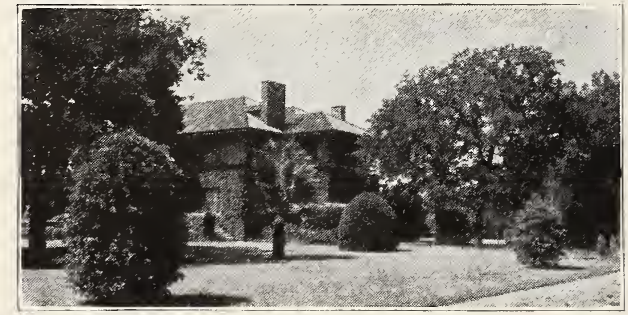

Trees Should be in Every Yard. The Bushes are Camphors-The Sheared Specimen, a Wax
If you do not desire a detailed plan and you only care to do a limited planting, we will be glad to send you an estimate covering cost of plants desired. In such cases we encourage customers to just send us a rough sketch of grounds (see page 6) and we will make a selection for you; there will be no charge for this service. However, where property conditions warrant, we advocate following architect's plan. 


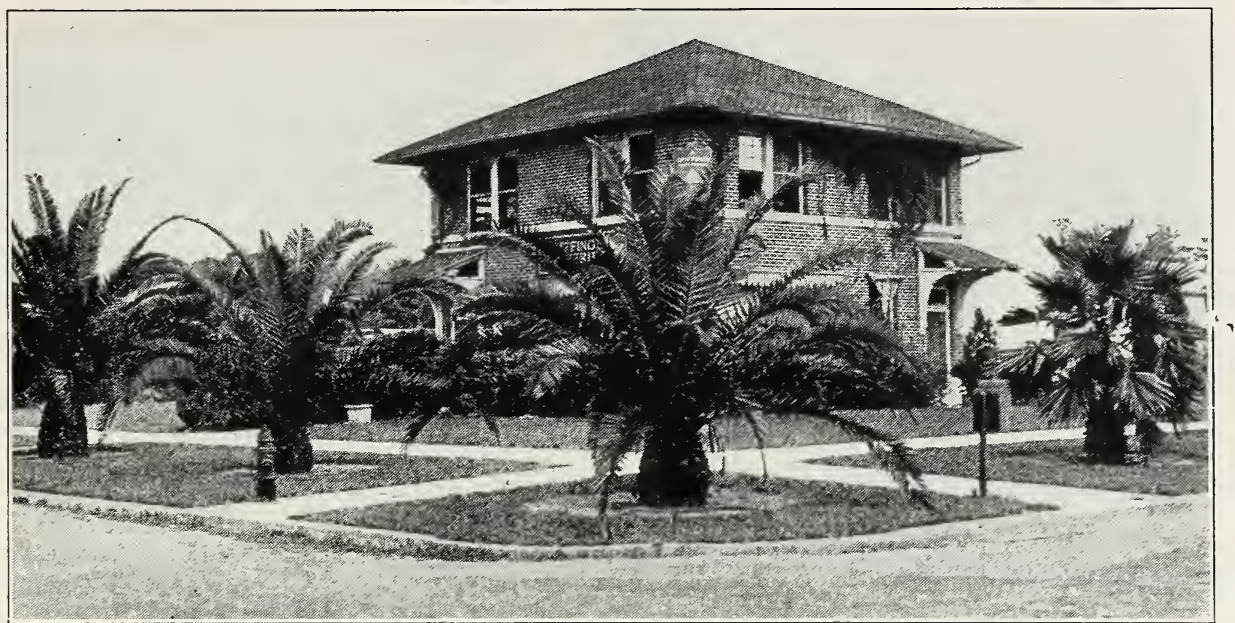

The Jacksonville Office, Greenhouses and Grounds.

\section{Our History}

NEARLY 40 years have passed since the present Griffing organization had their first inception in A small nursery plant in northern Florida on land owned by Father D. C Griffing and managed by his five sons under the name of Griffing Brothers. So successful were their efforts under the Griffing policies then adopted and since followed religiously, that their operations rapidly extended westward to the Rio Grande. Always the Griffings grew the stock they sold, offered the best of everything, experimented in every locality to find the most adaptable varieties, dug their trees with care, packed under rigid inspection, and in all their activities gathered and disseminated information for the benefit of their patrons.

Several years ago, State Nursery Inspection Regulations interrupted exchange of stock between branches, making it practically impossible for the extensive organization to continue under one management and made each branch an individual concern, automatically liquidating Griffing Brothers, and so was the beginning of the present nursery organization which continues to serve you. The Texas properties were taken over by Mr. W. C. Griffing who is now the owner of the business known as "Griffing Nurseries" and operated under that name. The Florida properties known as the "Griffing Interstate Nurseries," owned by C. M. Griffing and Co., Inc., is directed by Mr. W. D. Griffing.

This brief history is given to offer you assurance that your orders will have the personal attention of an organization of experienced workers gathered together in the various departments by a man who has devoted a life time to the development of perfect service, in supplying your nursery wants.

\section{Our General Catalog Goes To More Than Two Hundred Thousand People}

Think of the many thousand others who will see it through borrow ing and other ways. Then picture the magnitude of the business we are prepared to handle. Hundreds of thousands of trees and plants in many varieties and kinds. Is it any wonder that we can offer higher quality of plants, better values, and more efficient service than a smaller organization?

\section{Why Our Service is Best}

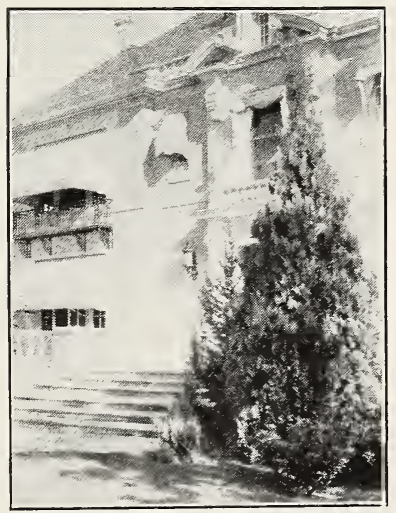

Illustrating the Importance of Large Plants in Your Planting.

In our immense concern it is possible for men to specialize and find the position for which they are best suited by nature and training and there they are much better equipped to serve than in a

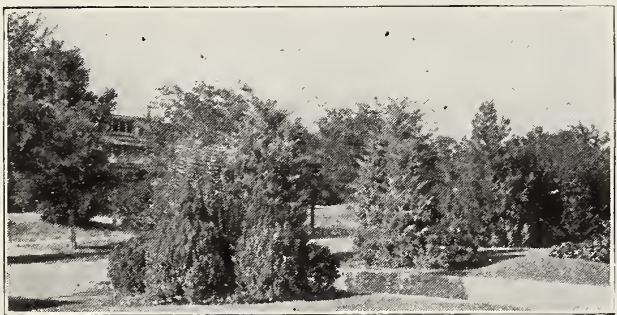

Landscape Groups-Conifers Predominating. smaller business where varied duties must fall to each.

\section{Why Our Prices Are Low}

With so many friends it is to our financial interest to maintain our record of nearly forty years and realizing this we are constantly alert to guard against errors and dissatisfaction from any source. If you multiply our volume of business by the years we have been in operation you can see the tremendous experience back of us. You gain by sending your orders to the largest concern for we can afford less profit, giving you the difference in lower prices and better plants. 


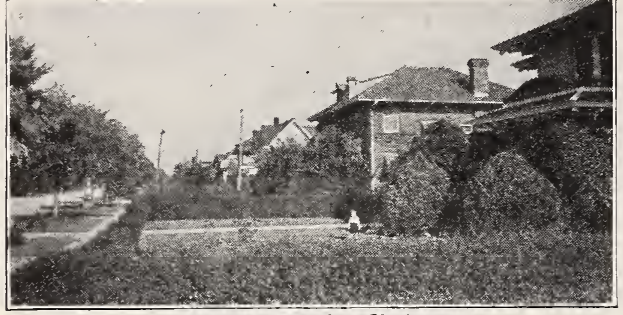

Sheared Camphor Hedge.

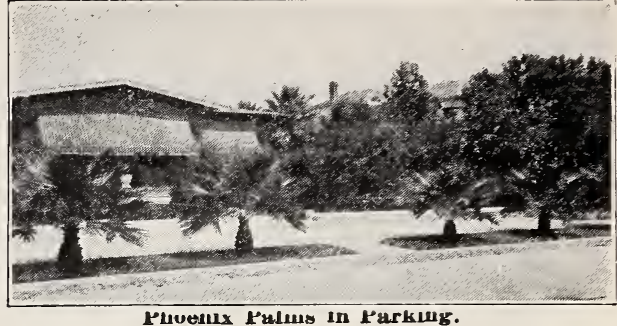

phoenix pulens in parking.

\section{This Catalog Our Leading Salesman You Pay No Agents' Commissions When You Order Direct From Us. All Your Money Goes for Plants. Think This Over}

The pride of any town or city is its beautiful yards. The interior of the houses cannot be seen by every visitor and it is by the exterior that they must judge. Make your home the pride of the family and of the neighborhood. A few of our evergreens, some of the flowering shrubs, a tree or two and a few cents worth of flower seed will make all the difference in the world. The cost is negligible and the effect is marvelous. You will be justly proud of your work.

\section{PLANTING MAKES YOUR HOME WORTH MORE}

Beautiful shrubbery, trees and flowers make your home more desirable and increase its value. Real estate men realize this and in the larger towns and cities have planting done before they offer a home for sale. A few fruit trees, some grape vines and berry bushes will give you delicious fruits at all seasons and the cost for trees and plants is less than the value of the ripe fruit gathered from the first crop.

\section{AN ORCHARD FOR PROFIT}

Commercial orchards pay large profits from small acreage and even the small home orchard will supply sufficient fresh fruit for the family, ample for canning and preserving, with a surplus for the local market. You have bought fresh fruit and know the prices you paid. Why not save this expense and make the profit by having an assortment of trees in your own back yard? We list only the best varieties that have been tried and tested and have proved their worth. You can't go wrong ordering from us.

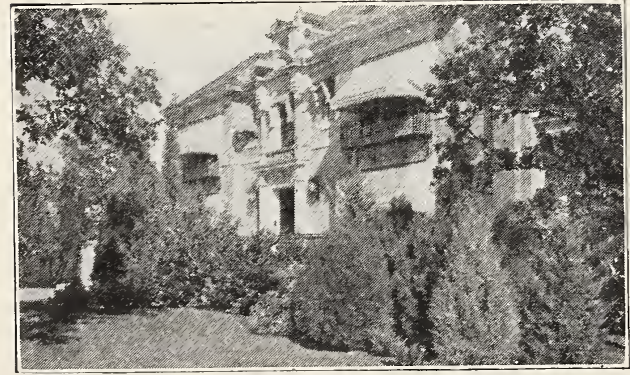

A Hardy Selection of Our Plants Used Above the Coastal Belt.

\section{FREE SERVICE DEPARTMENT}

Filling a Need of Plant Lovers

That is what we believe we are doing with our Service Department when we gather and disseminate information dealing with fruits, orchards, ornamental trees, and shrubs, landscape planting, shade trees, vines and those many beautiful and valuable plants which are adapted to the southern section of our country. Few nurserymen, florists, or landscape men are equipped and experienced to do this-the more need for us with 35 years experience in propagating and growing plants together with planting landscape projects and orchards to offer information gained in no way except by experience and practice combined with accurate technical knowledge.

\section{FREE BULLETINS ABOUT PLANTS}

To help you grow your fruits and ornamental plants successfully we have published a set of bulletins on various subjects and with one of these as a guide you can have excellent results although your experience is negligible. Write for the ones in which you are interested. They are free and we want you to have them. The list now ready for distribution follows:

Griffing's Service Bulletin No. 71, "General Fruits"Peaches, Plums, Pears, Persimmons, Grapes, etc. Treating on Variet, Adaptahility, Cultivation, Fertilizing, spraying and Marketing.

Griffing's Service Bulletin No. 66, "The Pecan"-Its Economical Value for every farm and home, and as a Commercial Money Crop.

Grifting's Service Bulletin No. 76, "The Fig"-As a Home Fruit and as a Staple Commercial Crop.

Griffing's Service Bulletin No. 56, "Shade and Ornamental, Trees, Shrubs, Roses and Landscaping the Home."-Suitable Trees, Shrubs and Flowers, and Their Proper Arrangement and Care.

\section{Your Attention is Directed to Our Special LANDSCAPE SERVICE}

And Department of Landscape Design.

We offer the most complete Landscape Service, including preparation of plans, supplying of plant material, and when desired, additional service of planting or superintending can be had. If you want the highest class service in the most e.conomical way, don't fail to write us about your plans. We plan any grounds, large or small. Corps of experts in this department.

\section{THESE PEOPLE NEED OUR SFRVICE}

Home Owners

Civic Club

School Boards

Real Estate Dealers

County Agents

Factory Owners

Factory Owners
School Superintendents City Officials

Park Commissioners

Cemetery Officials

School Faculties

Landscape Architect
Chambers of Commerce 


\section{Nut and Fruit Trees}

While we have greatly extended our business in Ornamentals and Roses during recent years, we have by no means neglected the great commercial lines of Horticulture so important to the South. We are constantly building up and increasing the production of Pecan trees, Fruit trees, Grapes and Small Fruits, for we find as those planted a few years ago come into bearing in all parts of the South, it is most impossible to keep up with the demand. So while we love the Ornamental side of the business, we have no inclination or could not afford to neglect the Fruits and Nuts.

\section{ORCHARDS}

The land that will produce the best farm crops will also produce the best orchards. Rolling, well-drained lands are best for all varieties of trees. Therefore, we urge that you do not plant our good trees on land too poor for other plantings.

\section{ARRANGEMENTS OF PLANTINGS}

Proper distance, that is, in allowing each tree plenty of room for spreading. Longer-lived and larger trees should be planted at a greater distance apart; the shorter-lived trees can be interplanted to a very good advantage.

If you wish information about Time to Plant, Preparation of the Land, Distance Apart, Cultivation, Fertilizers and Spraying for the Control of Insects and Diseases, ask for our General Fruits Bulletin No. 71.

\section{Griffing's Paper Shell Pecans}

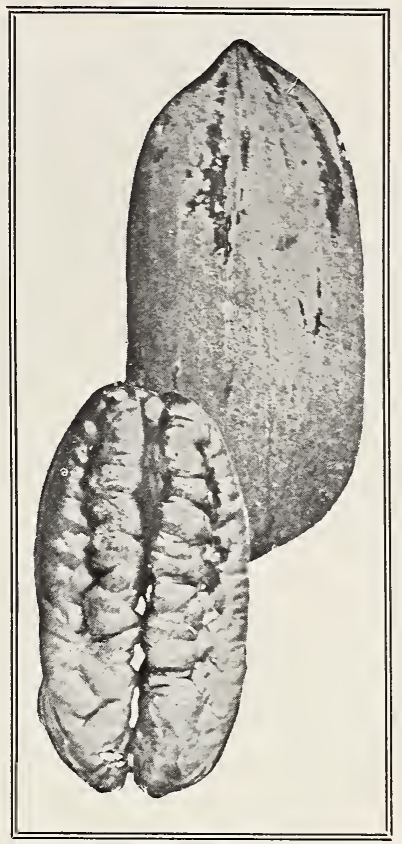

Pecans are the Highest Quality and Highest Priced Nuts in the World.

The improved Paper Shell Pecan nuts hold first place and command the highest price of all the world's nuts. Pecan nuts are in demand constantly at good prices for culinary purposes and for the making of candies, etc. Nuts are gradually taking the place, of meats in the staple daily diet of the world's people. In this the Pecan will assume first place, because it is the richest in nutriment of all the nuts.

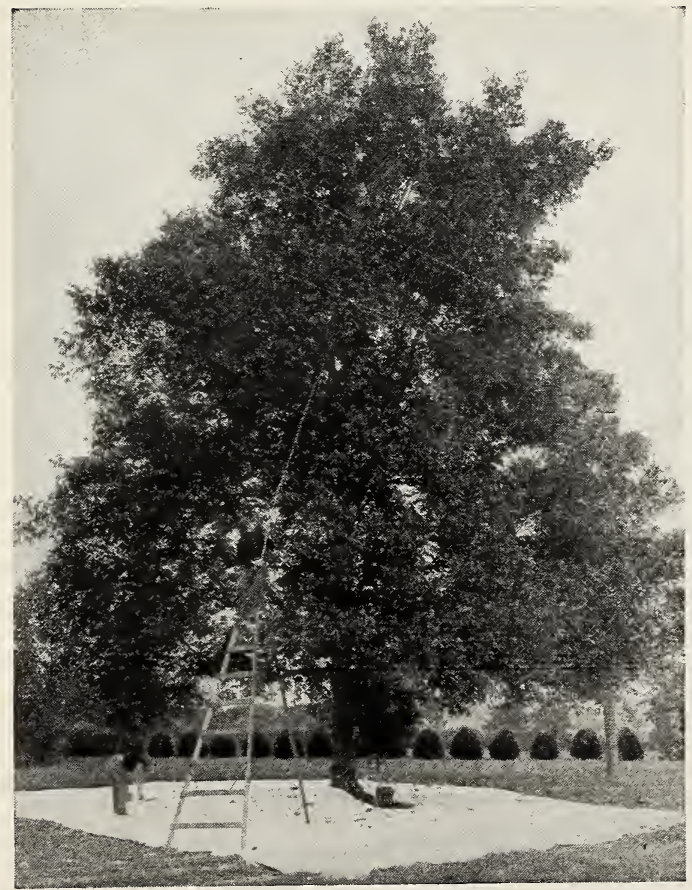

Harvesting Pecans.
The Kind of Pecans We Offer You

We have been closely identified with the development of the Improved Paper Shell Pecan industry since its first inception, and have originated, introduced and disseminated several choice varieties. We are owners of some of the South's largest bearing and young Pecan groves.

\section{Utilize the Waste Space on the Farm}

Pecan trees of Improved Paper Shell varieties planted along the roadsides, avenues, drives, fence lines and around barns and outbuildings will not only add a distinctiveness and character to your farm, but will in a few years yield a revenue in nuts sufficient to pay you.

All for the cost of a few trees and the keeping of the waste spaces cleaned and in order, as they should be on well kept farms. Pecans are a safe investment.

The growing of the improved varieties of Paper Shell Pecans has gradually developed until it has become one of the South's most important agricultural pursuits.

The Pecan is an Excellent Shade Tree

We are in position to offer some unusually fine trees in sizes 7 to 9 feet, 9 to 12 feet, and 12 feet and up. They are ideal for yard and street planting. Think of the beautiful shade tree they make, as well as producing the best nuts known today. All budded and grafted trees. No seedling trees offered.

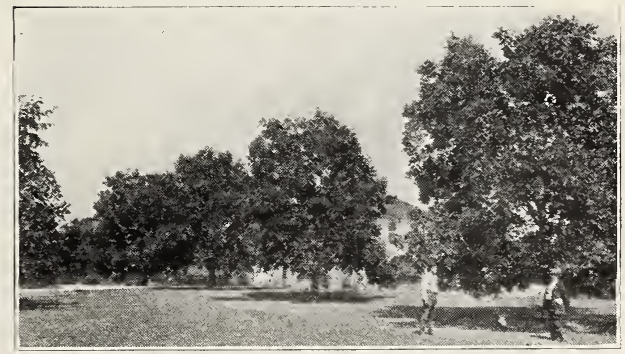

Twelve-year-old Pecan Trees from Griffing's. 


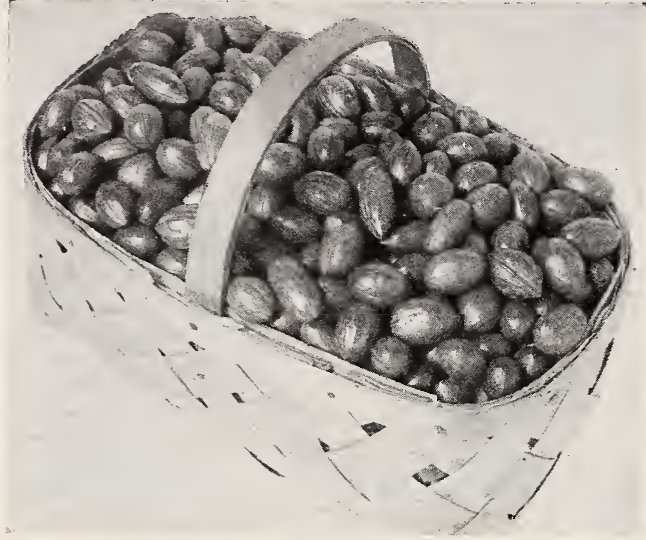

Basket of Pecans.

\section{How to Plant}

Trees should be planted at a distance of $45 \times 60$ feet apart, requiring 18 trees per acre. At this distance, other crops may be successfully and profitably cultivated between the rows of Pecans without detriment or injury to the trees. The cultivation of other crops while trees are young, actually benefits the Pecan trees and reduces the expense of upkeep to the minimum. We recommend the cultivation of corn, cotton and vegetable crops between the rows.

\section{FREE-SPECIAL BOOK ON PECANS-} BULLETIN No. 66 .

A special book of 32 pages devoted entirely to the growing and marketing of Pecans. We will be glad to send ycu this book free, if you are interested in

Pecans. The giant of all Pecan nuts; was introduced by us for the originator J. W. Zink, of Southern Mississippi. This variety bears very young, produces heavy clusters of nuts, 38 to 40 weighing a pound. The ideal variety for dooryards.

BRADLEY. Cracking quality excellent; kernels plump. Always takes first prize: at fairs on account of richAlways takes first prize at fairs on account of rich-
ness of meat. Tree of limber growth, withstanding ness of meat. Tree of limber growth, withstanding

dium to large nuts.
CURTIS. Tree vigorous. Open growth. Bears at early age. Thin shell; cracking quality exceptionally good: plump kernel of rich quality. While nut is smaller than other varieties listed it makes up in quantity and in cracking tests.

DELMAS. Size large, plump kernel; quality good; vigorous grower.
FROTSCHER. One of the best known varietles; remarkably thin shell; splendid cracking qualities; large size.

MONEYMAKER. It combines early maturity and heavy production.

NELSON. Very large, attractive nut, borne in clusters. Good flavor.

PABST. Sturdy, thrifty grower; productive; nuts large; one of the best eating nuts.

PRESIDENT. The nut probably embraces more of the characteristics of a perfect nut than any other Oblong, slightly compressed with a sharply pointed base; large size; texture fine.

SCHLEY. One of the best; kernel plump; superior in quality, richness, flavor.

STUART. A variety generally considered the standard by which other nuts are judged.

SUCCESS. Size very large; kernel usually plump; flavor good.

TECHE. Commences bearing very young; medium size; quality good; a profitable, practical variety.

VAN DEMAN. One of the most attractive in appearance. Very rich and well flavored. Medium to large, elongated. Each $10 \quad 100$

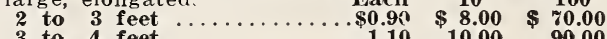
3 to 4 feet $\ldots \ldots \ldots \ldots \ldots \ldots \ldots, 1.10 \quad 10.00 \quad 99.00$ 4 to 5 feet $\ldots \ldots \ldots \ldots \ldots \ldots \ldots, 1.40 \quad 13.00 \quad 120.00$

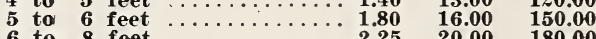

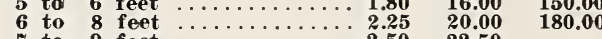

7 to 9 feet $\ldots \ldots \ldots \ldots \ldots \ldots+2.50 \quad 22.50$

12 feet and up ............. 4.00 up

\section{Japanese Walnut}

This tree produces the very finest type of full, rich, meaty kerneis. Can be removed whole for candie and table delicacies. The only walnut which thrives in the South. A beautiful tree of great value for shade and ornament; a credit to any ground.

1 to 2 feet

Each 10

\section{Cultivate Well and Get Results}

We cannot too firmly advocate cultivation of Nut Trees. You are aware of the large income they will bring you. If you want the best results it is imperative that you cultivate your trees well and give them excellent care and attention with out this proper attention it is impossible to expect ant who tells us that hew onc wears and then learned the proper care methods: wears and the that he neglected his trees for two trees that he planted later and did care for properly lected trees are now making fine development with good attention.

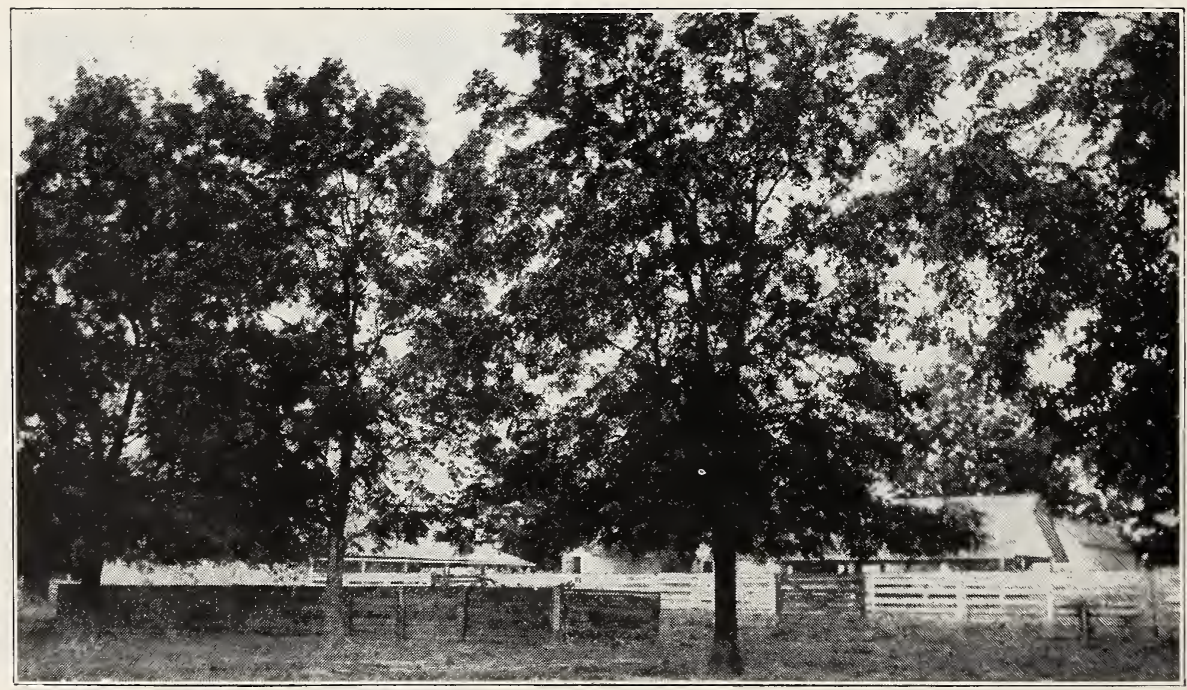

Pecans Producing Food and Affording Shade in What is Usually Waste Space. 


\section{Japanese Persimmons}

Are destined to become one of the leading fruits of the Cotton Belt and lower South. This may seem an Extravagant statement, but as soon as there is enough of the fruit on the market for the people to learn the richness and deliciousness, the demand will increase far in excess of the supply. Where the Persimmon is known on the market, it finds ready sale. COSTATA. Medium sized, conical nom ready sale. sided; skin salmon-yellow; flesh light yellow, almost

DIA DIA MLRU. Thrifty open-growth tree, distinct light foliage; fruit medium size, flat and four-sided. light foliage; fruit medium size, flat and four-sided.

FUYUGAKI. Of recent introduction from Japan. Tree vigorous, upright growth; fruit medium to large, nearly round, but somewhat flattened; skin smooth. tough; color reddish yellow; flesh meaty and of exceptionally good flavor. Bears young. Non-astrin-

GAILEY. The pollinating variety to be planted among other varieties; one to every seven or eight is recommended.

HACHEYA. Very large, oblong. Conical with rounded point: Reddish yellow. Trees vigorous and attractive. HYAKUME. Very large, roundish oblong, flattened at the ends; skin light, bluish yeliow; flesh light brown meaty, not astringent even while hard.

Yellow flesh, few seeds. Vigorous, sturd, attractive. very old age.

TAMOPAN. A Chinese variety of special merit. Fruit is large, somewhat flattened and with a compresse ring around it as though a string had been tied around the fruit while growing. Color beautiful golden red; skin quite thick and tough.

TANE NASHI. The best known and most popular variety; large, conical, pointed. Early bearer, early

TRIUMPH. Yellowish red, tomato-shaped, fine grained TSURU. Long pointed variety. Bright red, flesh orange color with darker coloring near seed, Proorange color with darker coloring near seed. ProYEDDO-ICHI. Roundish oblate, size large, color dark red; flesh dark brown, almost purple around the seed.

YEMON. Large, tomato shape; somewhat four-sided flesh yellowish; generally seedless.

ZENGI. Medium size, but one of the most valuable and 1 eliable. Tree sturdy, long lived and very proFach $10 \quad 100$

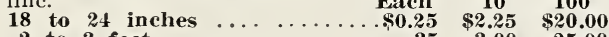
2 to 3 feet $\ldots . .35 \quad \$ 3.00 \quad \$ 20.00$

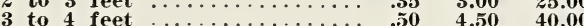

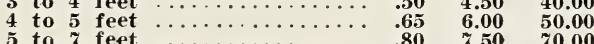
2 year, heavy branched ..... $1.40 \quad 12.50$ up

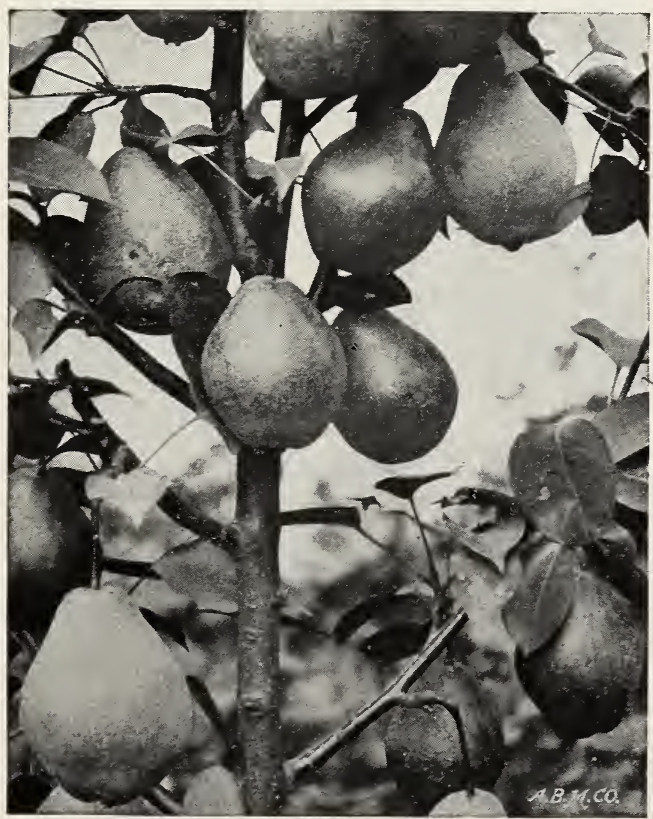

Kieffer Pears.

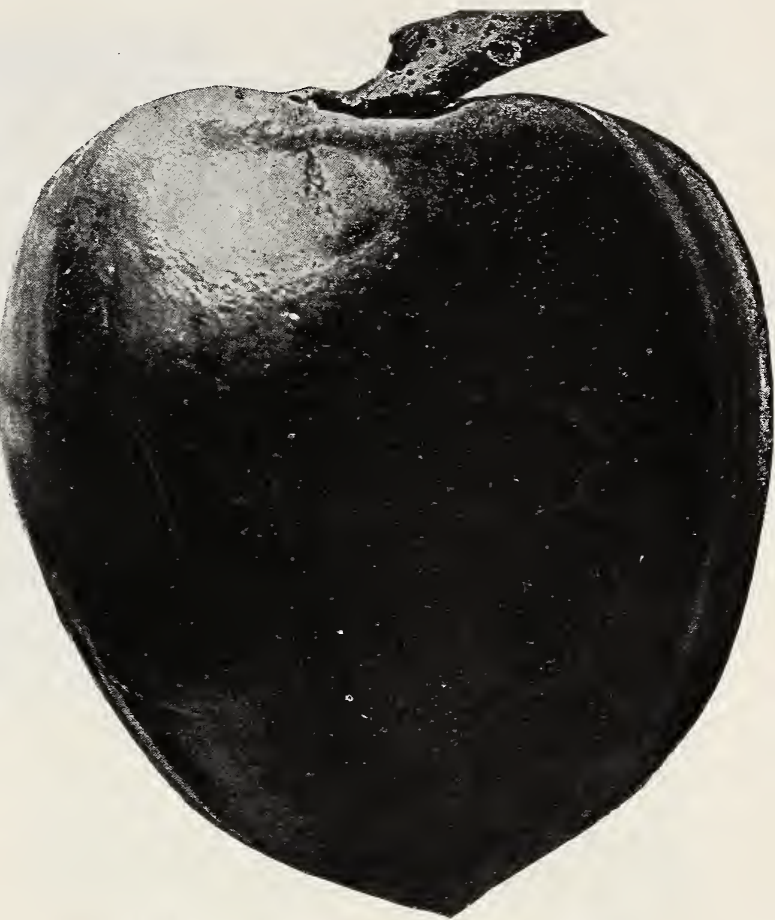

Tane Nashi Persimmon. Leading Market Variety.

\section{Pears}

The Pear is desirable and finds its greatest market value for canning and preserving. The Pear is the most economical of all fruits that can be grown for hogs during the summer and early Fall. Every home should have a few Pear trees and every farm a Pear orchard.

Our list of Pears is selected with special view to their adaptability to the lower south.

CINCINCIS. Thrifty grower, early, prolific bearer. Fruit large, light green, washed red. Bears in clusters. August and September. Adapted to all sections of the $\approx 04$ th.

GARBER. Rapid grower, good quaity. Ripens in KIEFFER. Large. The business Pear in many parts of the South. Late.

LE CONTE. Strong grower, early bearer. Fruit large,

SMITH. Fruit large, flesh melting, juicy, smooth,

ripens with or ahead of Le Conte.

\section{Blight Proof Pears}

Because of blight, the list of adapted Pears for the south is limited. Ours are from "Blight Proof" strains and are highly resistant to this disease, some being absolutely blight proof. A few trees will add considerably to your income.

DIXIE. A $n \in W$ variety originated in Southern Georgia. Crop is regular, very heavy, of fine quality and the trees have always been absolutely free from blight. PINEAPPLE (Sand). Name adopted by American Pomological Society. An excellent preserving or canning Pear. When cooked, holds its white color, not turning brown like most varieties of Pears. As an eating Pear it is fine when fruit is picked when nearly fully grown and ripened in a cool, dark place: is an absolutely certain shipper. Blight proof.

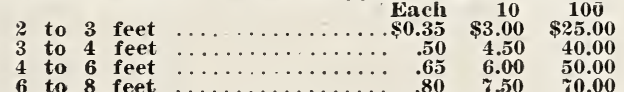

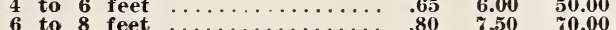

OUR STOCK IN NORTH CAROLINA.

Charlotte, N. C.

I like to do business with people like you, as my orders are always given such prompt attention and everything shows up nicely. 


\section{Peaches}

The Greatest Money Fruit Crop of the South

Every Southern state now has its commercial Peach growing industries in localities where enterprising citizens have demonstrated that by planting on well drained, natural forest lands and caring for their orchards according to approved methods there are greater profits to be made than in takings invo:ving such small investments.

ments. South, but not the same classes or South, but not the same classes or varieties to all sections.

Peach trees may be kept healthy an $y$ free from ravages of insects and disease by inexpensive modern meth ods, so that every family with even a few square yards of well drained soil can raise and enjoy this most delicious fruit.

Griffing's Service Bulletin No. 71, on General Fruits, treating extensively of Peach culture for the South, is invaluable for amateur fruit growers. Classes and varieties adapted to the various sections of the South are correctly defined. The successful modern methods of fertilizing and controlling insects and diseases by inexpensive means are duly described. This Service Bulletin free to all customers.

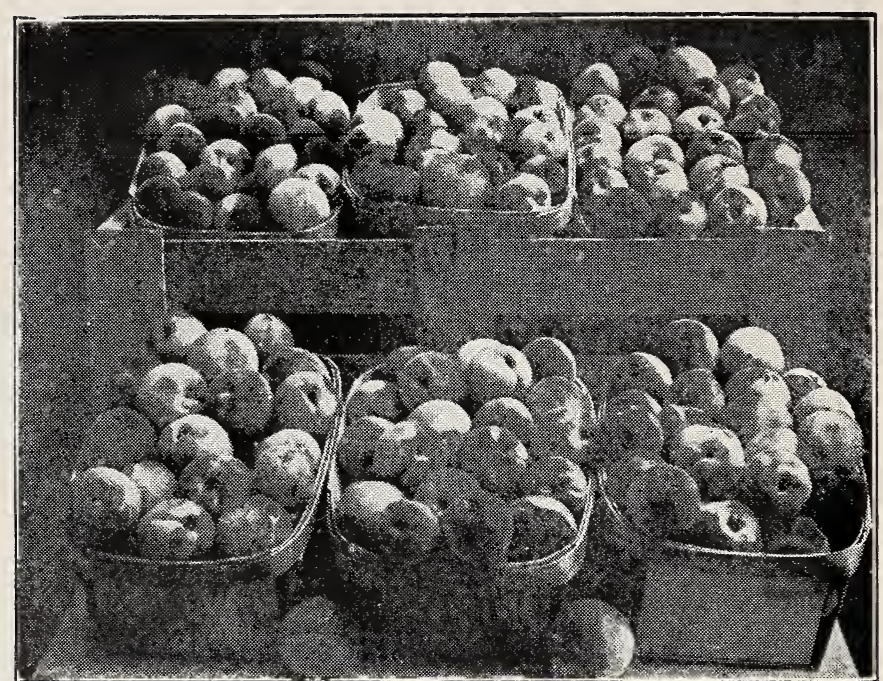

Jewell Peaches, Florida's Moneymaker.

GreatSouthern Peach Belt Varieties

ARP BEAUTY. Medium, oblong, yellow, blush tint. Flesh yellow, good quality. Freestone. Good commercial Peach. Ripe June 1st to 10 th.

BELLE OF GEORGIA. Large, showy, clear creamywhite, tinted red. Flesh white and firm, excellent quality. Freestone. July 1st to $15 \mathrm{th}$.

CARMAN. Large, creamy-white, tinged red. Freestone. June 20 th.

CHINESE CLING. Very large, white tinted red. July $15 \mathrm{th}$.

ELBERTA. Large, rich yellow, red cheeks, July. GREENSBORO. Large, bright red, flesh white. Semicling. One of the best. June 1st.

GENERAL LEE. Large, white with slight blush, quality good, splendid bearer. Cling. July $10 \mathrm{th}$ to HULE. Large, red cheelks, flesh white, red at pit. Freestone. June 20 th.

HEATH CLING. White with red tinge, flesh white. Cling. August.

J. H. HALE. Size large, flesh yellow, firm. Ripens a few days before Elberta. Freestone.

MAMrE ROSS. Large, flesh white. Cling. June 1st. MAYFIOUVER. Large, highly colored. Semi-cling. Very early.

NXX'S LATE. White, highly fiavored. Cling. September.

SLAPRY. Large, deep yellow. Early July.

TRIUMPH. Flesh yellow. Freestone. May to June. WADDELC. Rich, creamy-white. Juicy, sweet. Freestone. Early June.

\begin{tabular}{|c|c|c|c|}
\hline $\begin{array}{l}18 \text { to } 24 \text { inch } \\
2 \text { to } 3 \text { feet } \\
3 \text { to } 4 \text { feet } \\
4 \text { to } 5 \text { feet } \\
5 \text { to } 7 \text { feet. }\end{array}$ & $\begin{array}{c} \\
\cdots \\
\cdots\end{array}$ & $\begin{array}{rr} & \text { Fach } \\
\ldots & \$ 0.25 \\
\cdots & .35 \\
\cdots & .50 \\
\cdots & .60 \\
\cdots & .75\end{array}$ & $\begin{array}{r}10 \\
\$ 2.00 \\
\mathbf{3 . 0 0} \\
4.50 \\
\mathbf{5 . 5 0} \\
\mathbf{7 . 0 0}\end{array}$ \\
\hline
\end{tabular}

\section{PEACHES ON PLUM ROOTS}

Some people recommend the planting of Peaches grown on plum roots for the coast country as they are not affected by the Nematode (the insect that causes root-knot disease, the direct cause of short life of this class of trees), and plum roots will also thrive and give good results on land so wet that peach roots will not grow at all.

To meet this demand, we have grafted a large stock of all leading varieties on Marianna Plum Roots. We recommend that this class of trees be planted deep enough so there will be three or four inches of soil above the union of the graft and plum root, and soil above the union of the graft and plum root, and believe by this method Peaches can be grown in of the root-knot disease or from the land being too wet for peach roots.

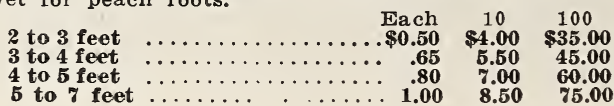




\section{Plums}

Recent crops of Plums in Florida and the lower South have convinced thousands of people that there is no better section for their extensive culture. Southern markets and homes were abundantly supplied with this most delicious fruit during the months of May and June, while the few that found their way to the northern markets met with no competition and brought most satisfactory returns.

We recommend more extensive planting of Plum trees. They should be grown in quantities for refrigerator car shipments and we believe a commercial plum orchard ofers today one of the greatest inducements to the man who wallts to engage in a pleasant and highly profitable horticultural pursuit. The Plum is a fruit that is easy to grow, bears young, crops preserving as well as marketing in a fresh state.

\section{PLANT PLUMS IN POULTRY YARD.}

The clean packed ground and high percentage of nitrogen in the chicken manure seem to be just what the trees require. The trees give right amount of shade during summer and admit sunlight during winter.

ABUNDANCE. Medium to large, round pointed; subacid. Rich and good.

BURBANK. Very large, clear rich red, showing yellow dots. Flesh deep yellow, firm and meaty.

EXCELSIOR. Remarkably strong growth, fruit medium to large size; reddish purple; flesh firm, yellowish. A most valuable southern Plum.

FLORIDA. A new Plum of the Japanese strain. Very large, abundant bearer. Reddish yellow; no

GONZALES. Very large, red, good shipper, fine quality. Originated in South Texas. June.

HAPPINESS. Very large, glowing red; flesh firm, rich, juicy. June 10.

HOYT. Bears in long clusters. Medium to large; purplish red. Meat dark yellow, pit small.

KEISEY. The largest Plum grown, heart-shaped; greenish-yellow, splotched with reddish-purple. July.

ICCARTNEY. Very early, oblong, transparent yellow; strong grower; productive. Very early.

RED JUNE. Vigorous grower. Prolific. Medium to large. Deep vermilion red, showy. Flesh light lemon yellow, slightly sub-acid. June.

STUMP OR HOWE. Medium large, dark rich red. Ripe in May.

TERRELL. Large, nearly round, reddish yellow, wine-red when fully ripe. Very fine quality. June 1 st.

WICKsON. Large, deep maroon-red. Flesh firm; deep amber-yellow, small pit. Ripe in July.

\begin{tabular}{|c|c|}
\hline $\begin{array}{l}18 \text { to } 24 \text { inches } \\
2 \text { to } 3 \text { feet } \\
3 \text { to } 4 \text { feet } \ldots \\
4 \text { to } 5 \text { feet } \ldots \\
5 \text { to } 7 \text { feet }\end{array}$ & $\begin{array}{r}\text { Each } \\
. \$ 0.25 \\
\quad .35 \\
. \quad .50 \\
. \quad .60 \\
.75\end{array}$ \\
\hline
\end{tabular}

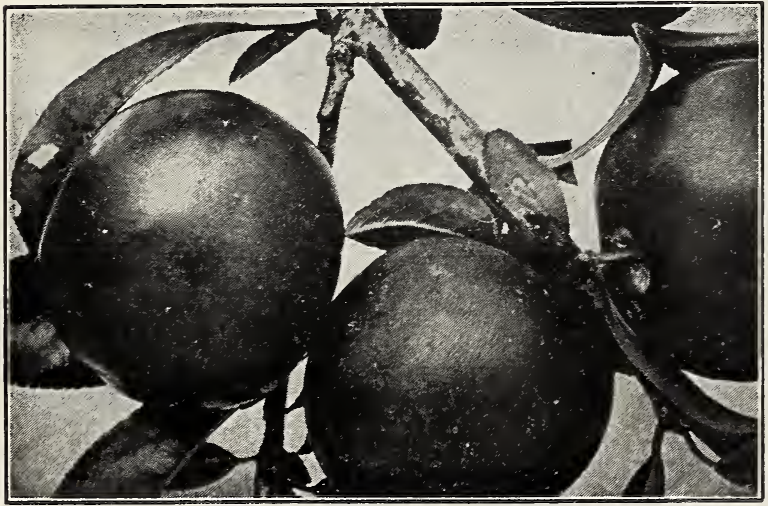

Hoyt Plums.

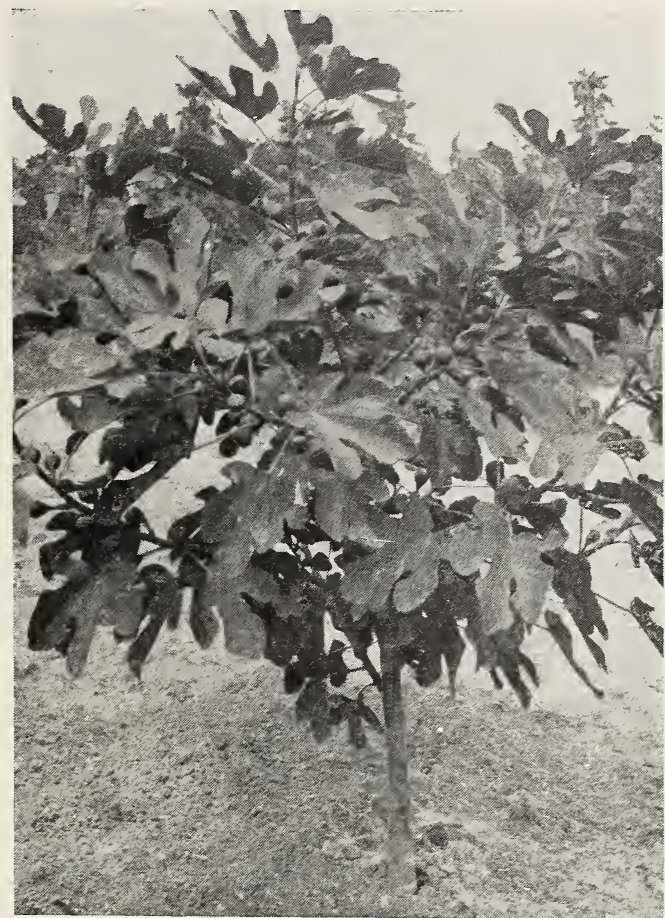

Fig Tree 18 Months From Planting.

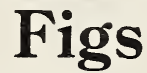

Figs thrive in all portions of the cotton belt of the South as in no other section of the world; trees may be found growing in door-yards, near trash piles, in chicken runs, and near buildings in a most luxuriant manner and producing enormous crops.

No home pantry is complete without canned and preserved Figs for Winter use. Figs come into bearing very early. With proper spraying to hold leaves on

mest on firm Trowth.

Commercial Fig Growing is extending throughout the South. They can be planted 10 to 18 feet apart and the yield is very heavy, thousands of pounds of fruit being produced per acre.

BROWN TURKEY. Medium to large; yellowish brown; pulp tender, rich and of the finest quality, borne on long stems, allowing fruit to hang blossom end down at maturity, preventing souring in rainy weather.

BRUNSWICK. Large, purplish black; good quality; early bearer; ripens throughout the season.

CELESTIAL. Sometimes called Little Sugar Fig; the sweetest of all varieties. Ripens

LEIION. Large, lemon colored, retaining natural color when preserved. Ripens early.

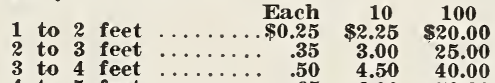

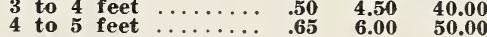

\section{Apples}

We do not recommend the Apple as a commercial possibility in the lower South however, the better early Summer types may be grown for home use.

EARLY HARVEST. Medium to large; pale yellow; rich, sprightly flavor. June.

HORSE. Large, greenish yellow. Popular southern variety. June 25 th.

RED ASTRACHAN. Medium to large, bright crimson; good quality and productive. June.

RED JUNE. Medium size, bright red. Good quality. June. 3 to 4 feet, 60c each; $\$ 5.00$ per 10 . 


\section{Mulberries}

For shade in back yards or lots and in poultry runs, the Mulberry is the best tree we know. The fruit.will feed chickens or pigs for months. Mulberry trees thrive in any location.

BLACK ENGLISH. A very prolific bearer, ripens early, providing poultry and hog feed for four or five months.

DOWNING. Strong, upright grower, thick, dark green foliage. Heavy bearer of good fruit.

HICKS' EVERBEARING. Enormous bearer; fruit ripening three months annually from June.

MERRITT. Finest Mulberry, The earliest variety; berries very large and full. Ripens during April and May. No farm complete without some Merritts. A place in every home yard for this tree.

RUSSIAN. A favorite; ripens in May; bears young. Berries nearly black. Fntirely hardy.

SILK WORM (Morus Multicaulis). Adapted to coast country; the famous silk worm tree. Special prices

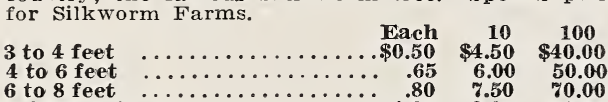

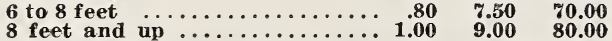

\section{Banana}

\section{(Musa Sapientum)}

No foliage so good in specimen planting or tropical effect for landscape massing and in most of the coast country produces nice bunches of really fine fruit. Grown throughout the South by taking up stalks in late Fall and burying, covering with leaves first, then soil. Soon makes beautiful showing when set out in Spring, leaving fruit buds intact. Each 10

Medium Bubs .....................\$0.50 $\$ 4.50$

\section{Pomegranate}

A novel southern fruit; highly appreciated by many and thrives well. Quite ornamental. Varieties: Sweet and Sour. 2 to 3 feet

2 to 3 feet

\section{Loquats}

or JAPAN MEDLAR (Eriobotrya Japonica). A conspicuously attractive small tree. Evergreen foliage. Bears yellow sub-acid plum-like fruit in very early Spring. Very desirable for its ornamental value and for fruit.

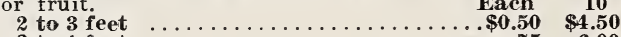

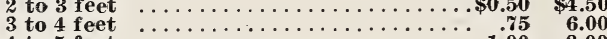

\section{Citrus Fruits}

We are in position to supply the very best quality of trees in all classes of Citrus fruits. For Central and South Florida, we recommend these trees budded on the Florida Rough temon Roots for planting on the high rolling pine lands, and the native Sour Orange Roots for level or flat woods land and all drained marshy or muck lands. For North and West Florida, South Georgia, and the coastal slections of South Caro"ina and the Gulf Coast states, the Citrus Trifoliate roots are best.

\section{Varieties of Oranges}

KING. Latest maturing of the Mandarin or kid glove type. Fruit large, fiattened, flesh deep orange color. Quality excellent.

LUE GIM GONG. A late orange of very superior quality; awarded the Wilder Medal by the American Pomolcgical Society for its late keeping and fine quality.

PARSON BROWN. Extremely early, standard round variety. The best orange in the market at its time of ripening. Medium size. Smooth skin.

PINEAPPLE. This is an ideal orange in shape, color and size; is unquestionably the finest flavored variety grown.

SATSUMA (On Trifoliate roots only). The great early market variety, always first on the market when prices are best. Adapted to all the heavy or when prices are best. Adapted to all the heavy or clay sub-soils of North Florida, South Georgia, and along the coastal set

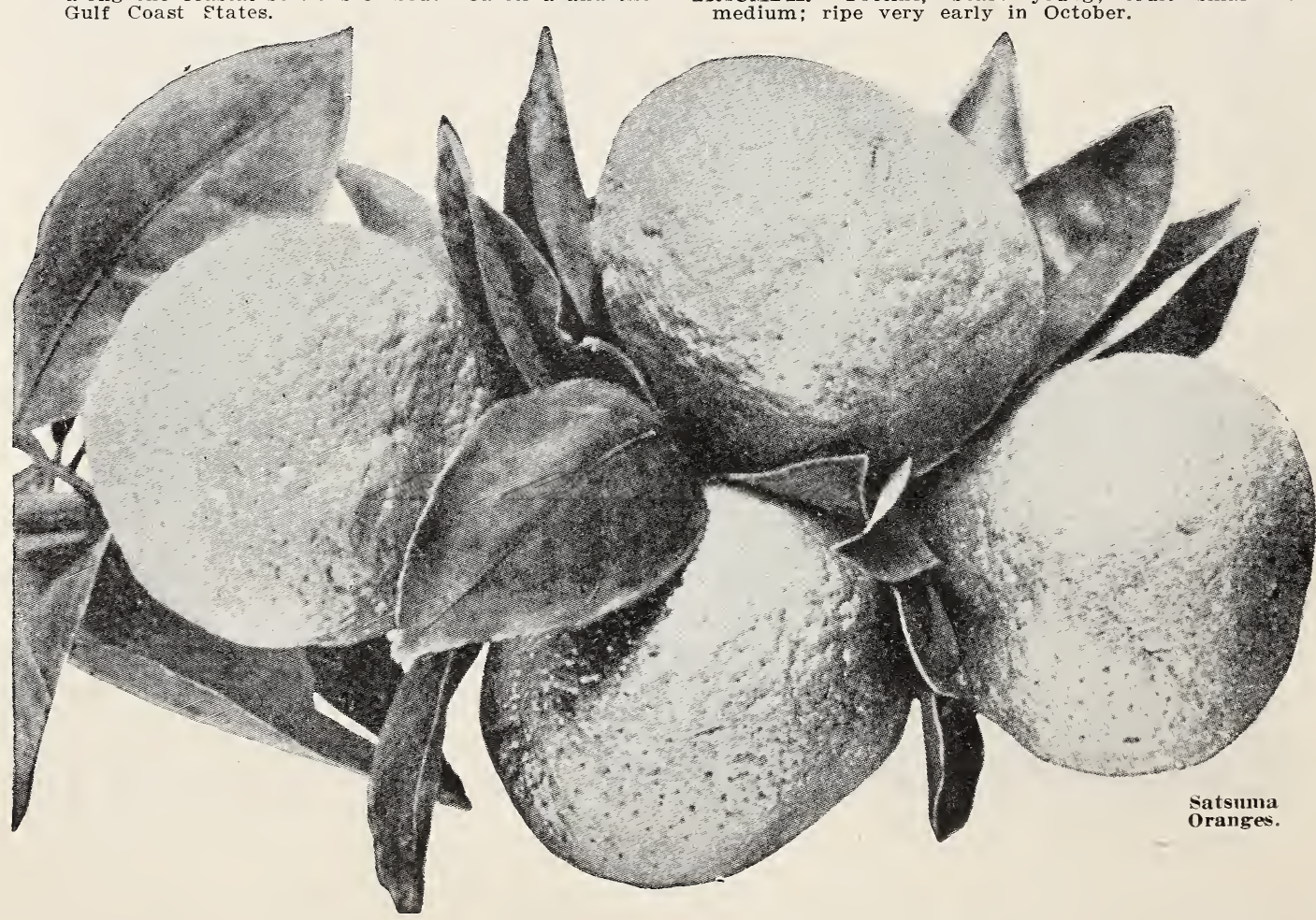

RUBX. Very early, dark, rich red. Ripe in early December. One of the best blood oranges.
TANGERINE. The best of the kid glove type. Small VALENCIA LATE. Very late, large size, oval-oblong, thin, tough rind, rich, juicy, semi-acid. Fine qualWASHINGON NAVEL. The orange that has made California famous as a citrus-growing state. Entirely seedl

\section{Varieties of Grapefruit (Pomelo)}

DUNCAN. Medium to large; fine quality; good appearance; heavy bearer.

in fruit popular.

MARSH SEEDLESS. Medium to large; very productive; bears extremely young; fruit popular on ductive, be bine nearly seding: active

monich. Prolic, bmall to to medium size, juicy, sweet, and of good quality. 


\section{Varieties of Lemons and Limes}

PONDEROSA LEMON. American Wonder Lemon. Large good quality, thrifty, prolific, early bearer.

VILLA FRANCA LEMON. Standard commercial varlety.

FLORIDA KEY LIME. Leading commercial sort from Fior: da and West India Islands.

TAHITI LIME. A large lemon-shaped Lime with smooth, thin rind; very juicy.

\section{Prices}

All Standard Varieties of Citrus, except Kumquats.

On Sour Orange and Rough Lemon Stocks. One-year buds on 4-year root system.

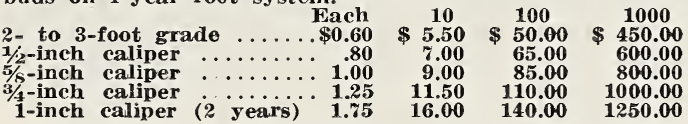

\section{Satsuma Orange}

The Hardy Orange for General Planting-in Great Demand.

The Satsuma does not do so well on any other root except the Citrus Trifoliate The early market Orange for the Coast sections. Satsuma is the hardiest Orange known. There is no risk in growing Satsuma on Citrus Trifoliate along the Gulf Coast. Begins bearing the second year after planting and becomes a profitable crop the third year thereafter. This is the ideal Orange to eat-the loose, tender rind or skin on the loosely adhering segments enable one to remove the segments or plugs and eat the fruit without the aid of a knife. Fruit medium size, flattened; color deep orange; flesh fin grained, tender, juicy, sweet and delicious, with a peculiar agreeable flavor found in no other Orange; entirely seedless. Tree entirely thornless.

Satsuma and other Standard Varieties.

on Citrus Trifoliate Stock.

\begin{tabular}{|c|c|c|c|}
\hline $\begin{array}{l}\text { to } 3 \text {-foot grade } \\
\text {-inch caliper } \\
\text {-inch caliper } \\
\text {-inch caliper }\end{array}$ & $\begin{array}{c}10 \\
\$ \mathbf{5 . 0 0} \\
\mathbf{6 . 5 0} \\
\mathbf{8 . 5 0} \\
\mathbf{1 1 . 0 0}\end{array}$ & $\begin{array}{l}100 \\
\$ 45.00 \\
60.00 \\
80.00 \\
100.00\end{array}$ & $\begin{array}{r}1000 \\
\$ 400.00 \\
550.00 \\
\mathbf{7 5 0 . 0 0} \\
\mathbf{9 5 0 . 0 0}\end{array}$ \\
\hline
\end{tabular}

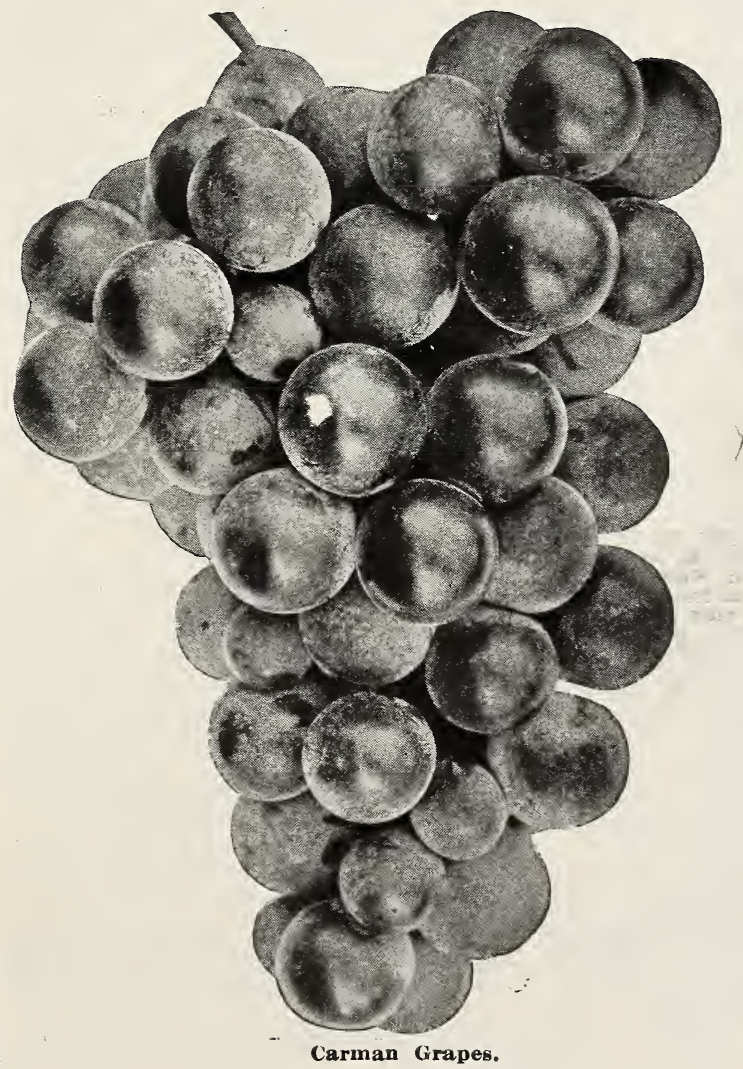

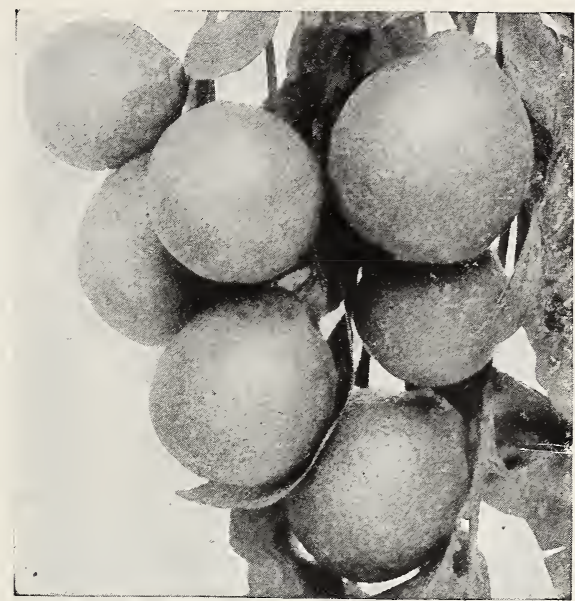

Lemons.

\section{Small Fruits}

\section{Grapes}

In the lower South two distinct types have proven their worthiness for general planting, choicest fruit per acre, be produced. The Grape should be more generally planted in the home garden and commercial vineyards. Every home in the South should have a shade arbor of some strong-growing variety of Grapes. SOUTHERN MUSCADINE CLASS.

This class of Grapes is native to the South and is well known and loved by all southern people. Fruit clusters not so large as the bunch varieties, but the flavor is excellent. For jellies, preserves, grape juices, wines and table use they are unexcelled. Usualiy trained on overhead arbors $6 \frac{1}{2}$ or 7 feet high, consisting of posts with wire or wood framework. Pruning is not commonly practiced. Plant 20 to 30 feet for arbors.

EDEN. Large, black; delicate flavor; large cluster; early bearer. Fine quality, productive, free from disease.

ELOWERS. Large, splendid quality. Very late. Black.

JAMES. Very large, purplish black. Rich sweet, juicy.

MALE MUSCADINE. If planted with other varieties of Muscadine Grapes, it will cause them to bear much heavier crops, as this is a pollinating variety.

MEISCH. New yariety: medium size earliest of this type. Delicate, rich, splendid flavor. THOMAS. Small cluster, medium size, red: Very fine quality. Early.

SCUPPERNONG. Large, bronze colored berry. Flesh sweet, pulpy and vinous: Vines produce abundantly.

BUNCH CLASS.

Not all bunch Grapes are at home in the South, but many grow here to perfection and can be planted in back yards or in commercia plantings with assurance of prolific bearing. The best trellis is the Munson three-wire trellis, consisting of posts with cross-bars at top with three wires strung over tops for vine support. This type is usually planted 8 to 10 feet apart. Prune each Winter, leaving runners in part direction but removing the majority of last year's growth.

CARMAN. Vigorous, free from disease; prolific, large cluster. Berry medium size, black, firm tender, fine quality. Very rich, superior flavor seeds easily leaving pulp. A popular stand ard variety for the Gulf Coast and genera South.

CONCORD. Blue-black, an old favorite.

IVES. Thrifty, productive, good shipper, large, bunch; berry large, black, pulpy, sweet. Good Grape. Good for shade arbors.

NIAGARA. White, large, showy, good market variety. 
GRAPES-Continued.

MOORE'S EARLY. Bunches small; berries very large, round, blue-black, flesh pulpy, sweet; quality good. Very early.

TAMPA A chance seedling that has been very successfully grown about Tampa, Fla., for some years. The introducer, Mr. O. Rossolech says of it"Bunches large, weigning up to $11 \frac{1}{2}$ pounds. Berries are medium, bluish black and ripen in June and July. F'ine flavor and very prolific. Never had a short crop. I have a vine planted six years ago that had 50 to 60 pounds this year. Another four years old yielded about a wash tub full." These are no exception, they all bear well and are healthy. There is no name for this new Grape so we are calling it "Tampa" at present. If a different name is ever agreed upon, will be glad to adopt it. is ever agreed upon, will be glad to

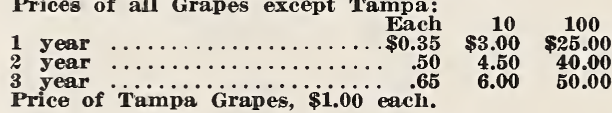

\section{Blueberries}

The Blueberry has recently come into notice. It has grown for many years in the lorests. Now they are being handled commercially. It has proven that there is a ready market for the berries. Trees come into bearing early. They ripen during the months of June, July and August. Fruit is dark. bluish black, of splendid texture.

Bulletin No. 974 of the U. S. Department of Agriculture, gives a record of a Blueberry orchard. The trees were seven years of age and yielded 95.8 bushels per acre, fruit sold at $\$ 966.00$ per acre.

Blueberries thrive best on soils so acid as to be considered worthless for ordinary agricultural purposes.

18 to 24 inches Each 10

\section{Guava}

CATTLEY GUAVA. A vigorous evergreen shrub standing sharp frosts, having handsome broad evergreen leaves. Fruit small, averaging about an inch in diameter: borne in enormous masses, ripening in August. Color a pretty red. Fruit is juicy and subacid, good in many ways. A fine plant, also of especial value for making hedges in South Florida, as it is unusually free from insect pests, such as white flies and scale.

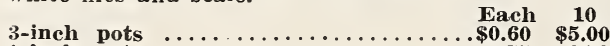

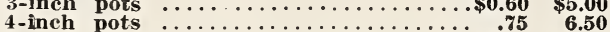

Best results will be obtained from digging a basin-shaped hole around each tree and shrub in late Spring, of sufficient size to hold a bucketful of water. In dry weather fill this natural basin several times a week. At Winter's approach fill in with soil and bank up against the plant so as to afford Winter protection, restoring the earthen basin in the following Spring.

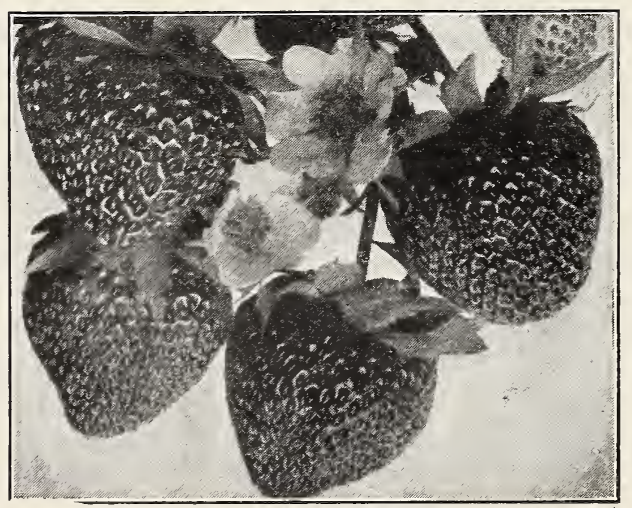

Glen St. Mary Strawberries.

\section{Blackberries and Dewberries}

The fields and woodlands of the lower South are the native home of Dewberries and Blackberries. There is no place in the world where they are more productive or the quality better.

The improved cultivated varieties offered here are the choicest of their kind and a few plants will give you a quantity of choice fruit during their season.

\section{CORY THORNLESS} BLACKB ERRY, Mr.

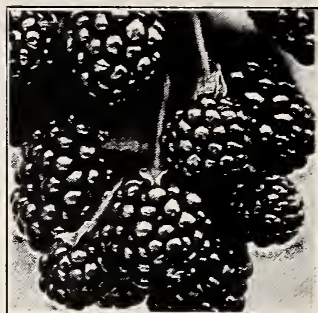

Blackberries.
Cory, the introducer, says that Thornless Blackberries are not an experiment any more; they are a fact. They have proven themselves to be superior in every way. Better flavored, heavier producers, better shippers an canners. They produce a good crop the second year after planting. Ripen early and continue to large and grow in clusters, making very easy picking.

\section{PRICES}

Strong, well rooted tips, carefully packed: Five tips for \$1.00 (smallest amount delivered); \$2.00 per dozen; $\$ 12.00$ per $100 ; \$ 110.00$ per 1000 .

Transplanted plants: Three plants for $\mathbf{\$ 1 . 0 0}$ (smallest amount delivered) : $\$ 3.00$ per dozen; $\$ 15.00$ per $100 ; \$ 125.00$ per 1000 .

MARVEL BLACKBERRY. Originating at or near Daytona, about 1908 , and recognized by Mr. W. W. Ballough (a trained horticulturist) as a very superior fruit. This is now our most widely grown "Blackberry," although it has the habit of a dewberry, with exceptional size and vigor. Should b grown on a trellis up to 5 feet high, with three to five wires. Produces heavily for three to five weeks in May and June, exceptionally large and juicy fruit that has met with instant favor at home, and promises much as a market fruit.

Price. 35c each; $\$ 3.00$ per 10 .

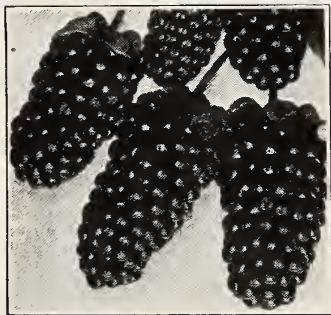

Dewberries.
LUCRETIA DEWBER RY. Berries are larger than any blackberry. Soft brightest glossy black color.

Price, strong plants, $75 \mathrm{c}$ per $10 ; \$ 6.00$ per 100.

AUSTIN DEWBERRY. Large, acid, vigorous prolific. Very early.

Price, strong plants, 65c per $10 ; \$ 5.00$ per 65c

\section{Strawberries}

GLEN ST. MARY. A new variety originated by $\mathrm{Mr}$ W. M. Ventling of Glen St. Mary, Fla., is a seedling W. M. Ventling of Glen St. Mary, Fla., is a seeding as the best of several hundred seedlings. Very large as the best of several hundred seedlings. Very large, often measuring $1 \frac{1}{2}$ by $1 \frac{1 / 2}{2}$ inches, requiring about four dozen berries per quart. The striking feature of this wonderful new berry are that they run very uniform in shape and size, a deep rich red both outside and through the flesh, which is very firm, making a grand shipper. Flowers self-pollinating. Ripens in midseason with Klondyke and produces more first class fruit than any variety we know. Try this out. You will not be disappointed.

Price, $\$ 2.00$ per $100 ; \$ 3.00$ per $250 ; \$ 8.00$ per 1000 . 500 at 1000 rate.

EXCELSIOR. Earliest to ripen of all Strawberries. Medium size, dark red, and so firm it can be shipped to distant markets. This will give you the earliest berries possible to get and good ones too. Perfect flowers.

Price, $\$ 1.50$ per $100 ; \$ 2.00$ per $250 ; \$ 6.00$ per 1000 500 at 1000 rate. 


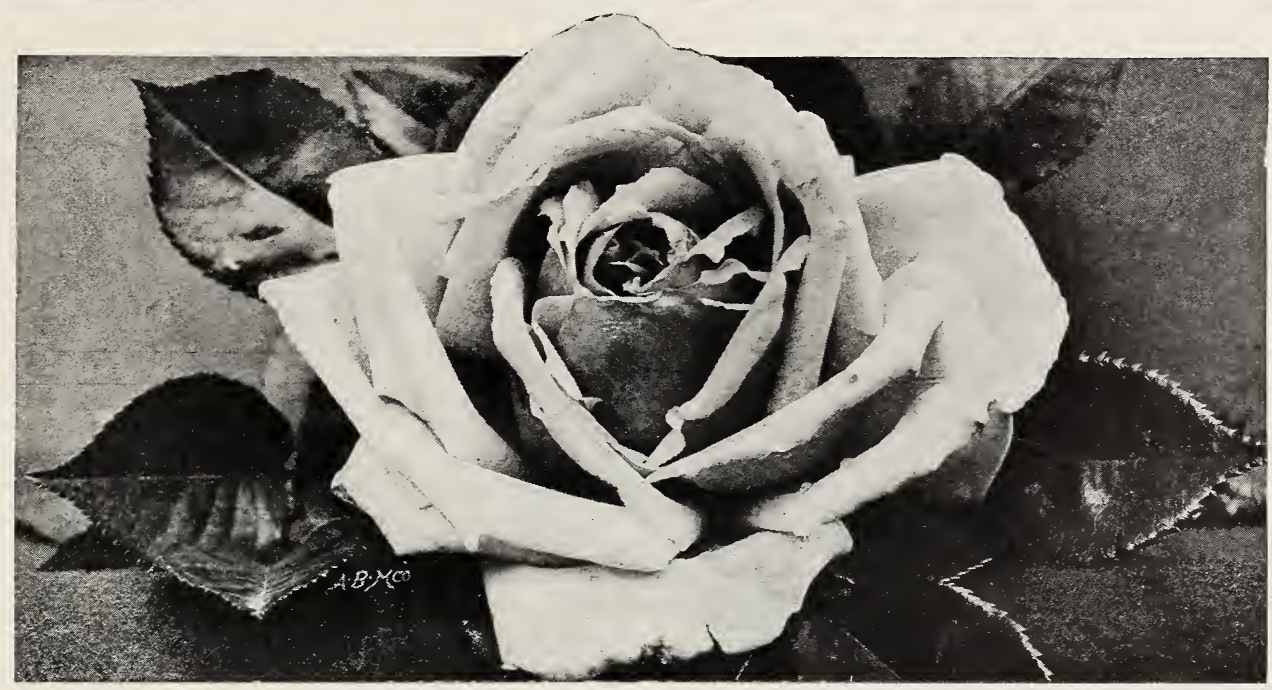

Alexander Hul Gray.

\section{Griffing's Roses the Qustly. Termed of Flowers}

Flant Roses More Than Any Other Flowering Shrub. Flant Roses More Than Any Other Fowering Shrub. They Bloom in Our Southland rom other Flowering Shrubs Months of the Year. Other Flowering Shrubs Seldom
Month.

Roses are the most popular flowering plant grown. We We cas bus, seldom have enough. By planting, our the growing and following our simple instructions, of Roses in the

The mild Winter, long Fall and Spring season, and abundance of rain during the Summer, give the lover of Roses in the southern states a more ideal climatic condition for growth in yard or open bed than any section in the world.

We offer only sturdy, field-grown Rose bushes that have actually proven themselves by producing an abundance of flowers in the nursery before they are dug and shipped. They are propagated on produce free-flowering, strong, shipping, plants are severely pruned and defoliated, conpruned and defoliated, conserving in the root, main stalk and body of the bush, ling them to push out strong. ling them to push out strong, sturdy branehes and produce an abundance of well developed flowers (when properly planted. manured and watered) in a surprisingiy short. time.

Our Rose Bushes are grown in the South especially for southern planting and will give sure and satisfactory results.

Such bushes should not be confused with imported plants, grown in entirely different soll and under different climatic conditions, that have been dug and kept in storage or transit months before you receive them, such as are sometimes offered by department stores, etc, nor should ours be compared with the weakly hot-house-grown pot plants, proparated on their own roots erom green propacated on the Nerth. There is no comparisons in in character of plants or in results.
Who Should Plant Roses. Everyone should plant Roses. There is no home, worthy of the name, where space could not be found for from ten to one hundred Rose bushes. If a renter, plant Roses; you will get returns in beautiful flowers in from two to three months. If a flat dweller, and you have three or more windows, you can plant ten or more Rose bushes in windows, you can plant ten or more window boxes. The result will be a delight, and you can move the window boxes with other personal benoving day comes around. If a hom owner, it matters not how pretentious or humble, nothing can make it more homelike, more attractive and inviting, than landlord, there is no improvement that can be made at so small an expenditure that will so quickly enhance the rental value and desirability of property, insuring permanent tenants, as a good Rose planting. Our Roses Are Known Throughout the South because they are vigorous and successful wherever planted. Many customers have placed orders with us for twenty years. If you want Roses you can do no better than plant the Griffing Everblooming types.

\section{Strong Field Grown Budded or Grafted Roses}

Classification: Roses are descended from several distinct classes or families, and the folowing key will enable one to find to which strains or classes each belongs. ( $\mathrm{H}$. P.), Hybrid Perpetual. ( $\mathrm{H}$. T.), Hybrid Tea. (BK) Banksia. (Bour.), Bourbon. Beng.), Bengal. (N.), Noisette. (Poly.), Polyantha. (H. Ch.), Hybrid China. (H. N.), Hybrid Noisette. (T.), Tea (Cl.), Climber. (H. W.), Hybrid Wichuraiana. (Laev.) Laevigata.

Prices of all Roses, exc below: all Rach 10 as noted

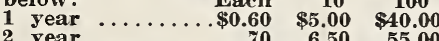
Prices of Rediance .70 $6.50 \quad 55.00$ Charles Bell. embourg:

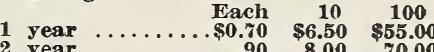
Prices of ail Bush and Climbing Roses. Balled and Burlapped, $\$ 2.00$ each. 


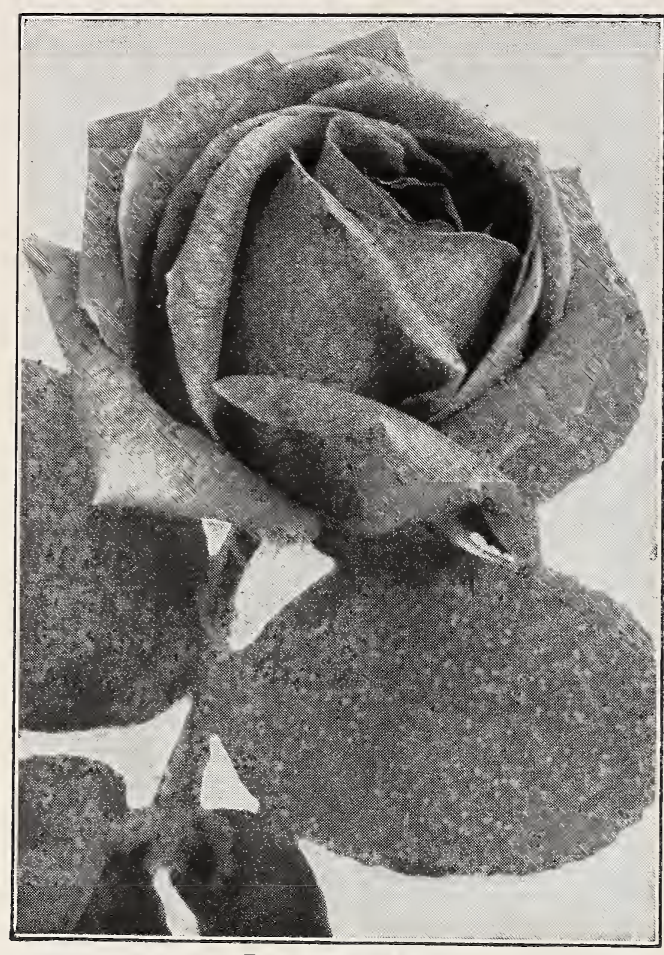

J. B. Clark Rose.

\section{Bush Roses}

Tree Roses: Radiance, Red Radiance, Mrs. Dudley Cross, Mrs. Charles A. Bell:

Straight bodies, bare-rooted

Each Straight bodies, balled

ALEXANDER HILI GRAY. (T). Color is deep lemonyellow, which intensifies as the blooms develop; flowers large, of g:eat substance and perfect formation; it has a high-pointed center from which the petals gracefully reflex.

ANNA MULI.ER. (P.) Plant stronger and flowers larger than the Baby Rambler type of Polyantha Roses. Color is briliant pink. It is very foriferous and sweetly is briliant pink. It is very floriferou
scented. Excellent for border planting.

ANTONNE RIVOIRE, "Mrs. Taft." (H. T.) Creamy-white; delicately tinted with pink, extra large petals making a bloom of decidedly distinct and beautiful form; full and double. Medium upright growth and exceedingly well adapted for garden culture; one of our best.

BABY RAMBLER, CRIMSON. (P.) The Crim son Rambler in dwarf form, with the same clear, brilliant ruby-red color. Hardy and healthy.

BLACK PRINCE. (H. P.) Velvety crimson with shadiligs of purplish-black. Upright, strong growth.

BRIDE. (T.) Most dainty, white with tinge of pink; with exquisitely beautiful long pointed pink; with exquisitely beautiful long pointed
buds borne on stiff, upright stems. Vigorous ouds borne on

BETTY. (H. T.) Fine long buds, brilliant coppery rose with golden suffusion. Good foliage strong, spreading growth.

BON SILENE. ( $T$.) Bright crimson-rose; large, beautiful buds and blooms with very long petals; a well known old-timer, . ever fresh and new.

BURBANK. (Bour.) Splendid symmetically formed cherrycolored blooms. Good grower and very free bloomer.

CAPTAIN CHRJSTY. (H. P.) Delicate peachblow-pink, center richer in color; large and full.

CHAS K. DOUGLAS. (H. T.) Bud large, long pointed; flower large, full, double, sweet fragrance; color intense flaming er large, full, double, sweet fragrance; color intense flaming disease resistant: vigorous, upright grower, produces an disease resistant: vigorous, upright grower,
CHERRY RIPE. ( $\mathrm{H}$. T.) Light clear cherry-red. 'A free bloomer, medium upright grower

CLIO. (H. P.) A vigorous grower producing handsome foliage; large, globular flowers of flesh color shaded to the center with rosy pink. Similar to Margaret Dickson.

COLUMBIA. (H. T.) It is a big Rose, the open flower measuring six inches across. The color is a true pink about the shade of a perfect Shawyer, deepening as it opens to glowing pink. A peculiarity intense until the full maturity of the open flower is reached and this color is enduring; a great Rose.

DUCHESSE DE BRABANT. (T.) One of the best allround roses ever introduced. Healthy grower, in constant bloom all the year. Beautiful cup-shaped blooms of delicate bright shell-pink. Large, spreading growth.

DUCHESS OF SUTHERLAND (H. P.) Large, shapely buds and fine open flower of peach pink, strong up-

ERNA TESCHENDOREF. (P.) The flowers are of a deep crimson color, flushed with carmine, resem bling the dazzling color of "Gruss an Teplitz." It is much sought after in America to bloom in pots during Winter and for Easter time.

ETOILE DE FRANCE. (H. T.) Lovely shade of clear velvety crimson. Fine cupped buds borne on clear velvety crimson. Fine cupped buds borne on
strong, stiff stems. Profuse bloomer; spreading strong,

ETOLE DE LXON. (T.) Beautiful chrome-yellow. Pure golden center.

EUGENE MARLTTT. (Bour.) A grand garden Rosenone better, being exceptionally healthy, vigorous and free blooming. Flowers large, very double, a rich bright crimson; fragrant.

FRANCIS SCOTT KEX. (H. T.) An American seed ling, raised by John Ccok. It is a heavy, double Rose of great substance. In color, red; it shows good growing characteristics and is undoubtedly a valuable variety. Throughout the Summer this Rose was unequalled as a cut Rose, and is proving equally good in mid-Winter tu be an excellent grower, opening perfectly and worthy of unqualified recom mendation.

FRAU KARL DRUSCHKI OT WHITE AMTERICAN PEAUTY. (H. P.) One of the purest white roses known. Very large blooms with immense petals o splendid substance; borne on stiff stems. Upright.

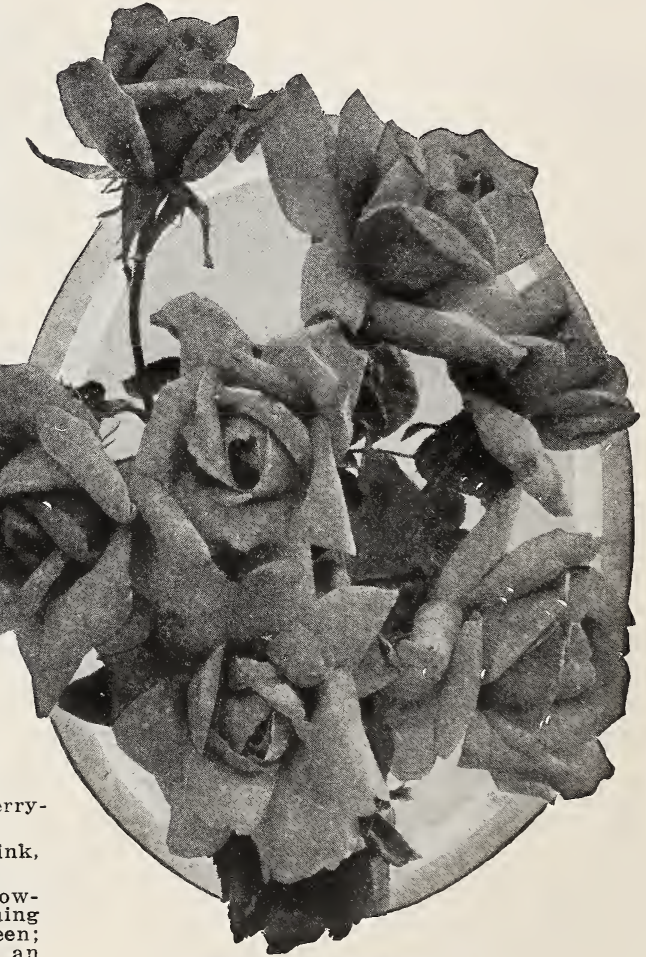

Mrs. A. R. Waddell Roses. 
ROSES-Continued.

FREIHERR VON MARSCHALL. (T.) Deep carmine-red; long, well shaped buds and large, full flowers of imstant bloomer with beautiful foliage. Medium spreadins growth.

GENERAL JACQUEMINOT. (H. P.) Bright, shining crimson; very fragrant, free bloomer.

GENERAL MCARTHUR. (H. T.) Brilliant scarlet, large and double, borne on good strong stems. Small upright grower.

GENERAL ARNOLD JANSSEN. carmine color a deep glowing carmine. Free bloomer. Buds ing growth.

GRUSS AN TEPLITZ. (H. T.) Bright crimson, white, fiery red center; cup-shaped; semi-double; flowers in clusters; so free in bloom as to present a blaze of scarlet.

HELEN GOOD, “VIrs. Dudley Cross." (T.) Beautiful, creamy white with delicate edgings of carmine at edge of petals and base of petals rosy yellow. Fine formed buds pening into full, double blooms. Good bloomer. Strong, vigorous grcwer of spreadiug habit. Thornless.

J. B. CLARK. (H. P.) Intense flaming scarlet. Well formed, cup-shaped blooms of splendid substance borne on upright, stiff stems. A strong grower and should be in every Rose garden.

JONKHEER J. I. MOCK. (H. T.) Blooms are of the largest size, highiy perfumed. Color clear imperial pink A gold medal winner.

JUSEPH НILL. ( $H$. T. Salmon-yellow with pink edges; long buds and full flowers of great substance. Small upright growth.

KAISERIN AUGUSTA VICTORIA. (H. T.) Pure white, with shadings of primrose-yellow.

KIILARNEY (Pinli). (H. T.) The popular Irish Rose. Semi-docible with immense petals of good substance. Beautiful in the bud. Glowing pink. Vigorous, small, upright growth.

KILLARNEY QUEEN. (H. T.) Same habit of growth and free-blooming qualities as its parent, the Killarney, while its splendid petals are even larger and of a more glowing pink.

KILLARNEY (White). (H. T.) Same good qualities of growth and habits as its parent, the Killarney, only petals are pure white.

LADY HILLINGDON. ('T.) Pointed buds of briliant deep golden yellow. Awarded gold medal, N. R. S.

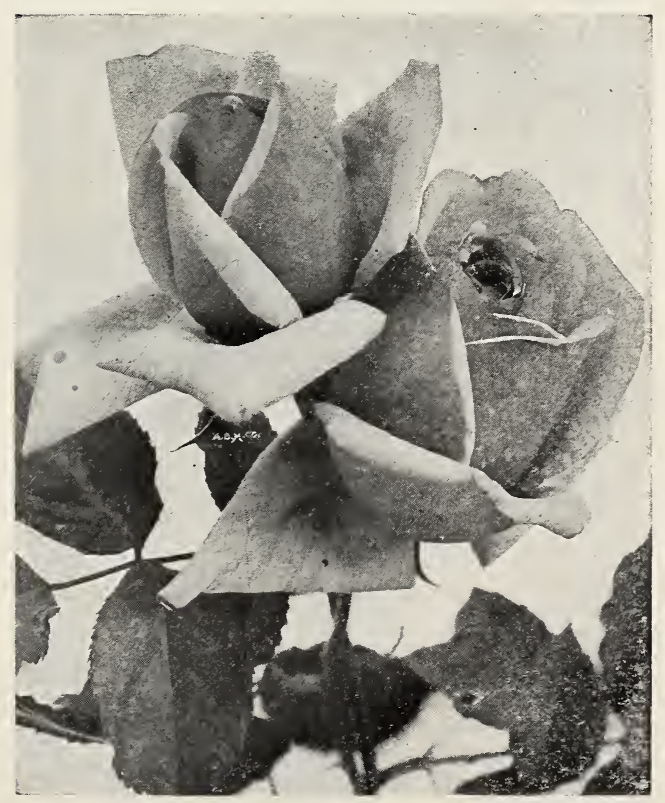

LADY PIRRIE. (H. T.) A popular Hybrid Tea Rose Color reddish salmon, petais apricot inside. Has good form and is a vigorous, upright grower.

LA REINE. ( $H$. T.) Clear, bright rose; large, fine full form, fragrant and hardy.

LA DETROIT. (H. T.) Soft, velvety rose, beautiful long buds opening up well. Medium, upright growth

LIBERTY. (H. T.) Flower brilliant velvety crimson; large, fairly full, long bud opening well. Growth vigorous, erect, very free flowering. First class Rose.

Luxemburg ( $H$. T.) of recent introduction, best yellow proving to be one of the very Produces on long stems; pointed buds; an excellent variety for cut flowers. Strong, upright grower and profuse bloomer.

LOUIS PHILIPPE. (Beng.) Another old favorite. In bloom all the year, and this endearing quality, with the rich velvety crimsor: of its blooms, perpetuates its name among Rose lovers. A bed of these is alway 3 bright. Strong, spreading habit.

IAD. DE WATTEVILLE. (T.) Creamy white, double, fragrant blooms. Good grower and bloomer

MAD. JOSEPH SCHWARTZ. (T.) Much the same style of growth and bloom as Duchesse de Brabant, and is sometimes called the White Duchess Beauty cup-shaped blooms of silvery white, softly shaded most delicate pink. Very free bloomer. Vigorous, spreaōing habit.

MAD. JULES GROLEZ. (H. T.) Bright, rich, rosy red blooms of splendid substance on good, stiff stems Beautiful foliage, good grower and bloomer. Spreading hahit.

MAD. P. EULER Or PRIMA DONNA. (H. T.) A lovely shade of vermilion-pink changing to si.very pink; very large and full, of perfect form and fragrant; free. vigorous and upright.

MAD. LOMBARD. (T.) Beautiful tint of rosy bronze. fawr. and salmon. One of the old favorites that no ore is willing to be without. No garden is complete without them. Vigorous grower, free bloomer spreading habit. 


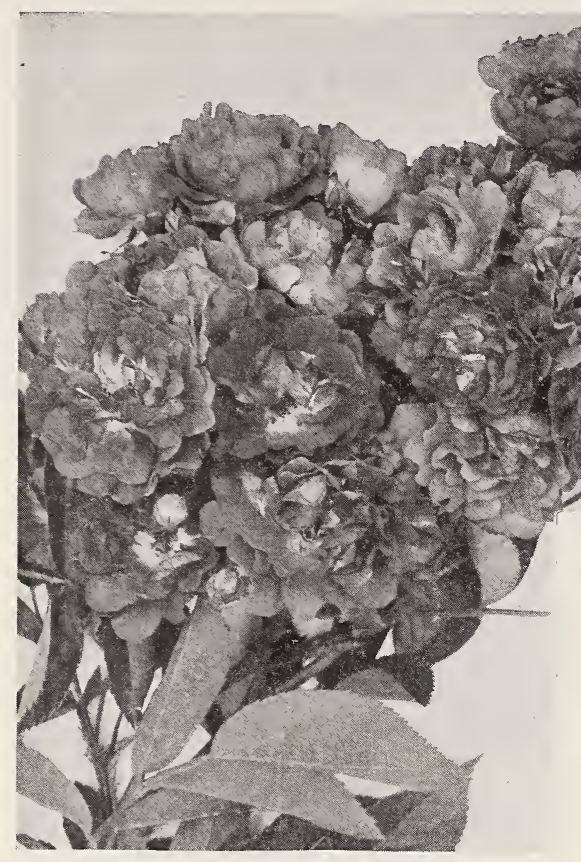

Crimson Rambler Roses.

ROSES-Continued.

MAD. BUTTERFLY. (H. T.) Is Hill's glorified sport of Ophelia. All the color tones of Ophelia are intensified, making it a harmony of bright pink, apricot and gold. The tight buds are a lovely shade of Indian oak, yellow at the base; they are unique for low table decorations.

MAD. CECILE BRUNNER. (H. Poly.) This is the popular Baby Pink or "Sweetheart" Rose. The past year or two this Rose has fairly jumped into popularity. It has become quite the rage. It makes a handsome miniature Rose, coming in sprays saimon-pink; distinct and desirable.

MAD. MELANIE SOUPERT. (H. T.) A superb fancy everblooming Rose; of strong, vigorous growth and free branching habit. Color golden yellow shaded to orange-yellow at base of petals, the whole beautifully fiushed with orange-pink. Fine long, pointed buds of elegant outline, opening into a very large fluffy flower of great beauty.

MAGNA CHARTA. (H. P.) Extra large, full flowers of unusual depth; sweet and of fine form; bright rosy-pink in color, one of the hardiest and best bloomers.

MAMAN COCHET (Pink). (T.) Rosy pink, shadings of silvery rose. A splendid Rose of sturdy habits. Fine buds that last well cut, of large size and opening into full, double, fragrant bloom. Medium spreading grower.

MAMAN COCHET (White). (T.) Of same sturdy habits, size, bloom and delicate fragrance as the Pink Cochet, and of such a pearly white and such exquisite shadings of most delicate pink that it is easily ranked as one of the few best Roses.

MARGARET DICKSON. (H. P.) White with delicate flesh center. Best of white perpetuals. Vigorous, upright.

MAURICE ROUVIER. (T.) Strong growing, sturdy variety, producing an abundance of very large, full buds of a bright rosy pink, suffused with buff and crimson veins. Sometimes bordered with silvery pink. Very

MIGNONETTE. (Poly.) Clear pink tinted with pale rose; very double and delicately perfumed. A perfect miniature Rose.

MRS. A. R. WADDELL. (H. T.) Buds long and pointed, of the deepest apricot yellow, delicately fragrant. Open flowers large and sem!-double, lasting well. Spreading habit.
INNIE FRANCES. (T.) Rich chamoisred, shading to velvety crimson. Most vigorous grower maks a shr Buds daintily long and pointed.

IRS. CHARLES BELL. See Special Radiance

CANT. (T.) Color deep rose; nner petals soft silvery rose suffused with

NATALIE BOTTNER or YELLOW KAISERIN (Bottner, 1911). (H. T.) Delicate creamy yellow; large, full, perfect form of both "Kaiserin" and "Druschki."

APA GONTIER. ( T.) Long, brilliant, cherry-red buds, semi-double, producing abundance of bloom at all seasons. Medium, upright growth. An oid favorite.

IERRE GUILLOT. (H. T.) Large, handsome buds opening to flowers of the deepest, richest red. Medium, upright growth.

(H. P.) Largest Rose known, even surpassing hot-house American Beauties. Deep rosy pink, full, double ooms with spicy fragrance, borne on strong, upright stems.

\section{The Great Radiance Group}

For outdoor culture in the South, we consider these THRE of all Roses. For cut flowers, they right from the omen) for the greatest part of the year. Wonderful free bloomers, strong growers, large, shapely THE COUNTRY TODAY.

H. T.) Flowers are a beautiful shad

Radiance of the richest tone of pink, darker on the inner surface of the petals than on the margins. ers of the same exquisite form, the same sweet perrume, as Radiance. The color is a splendid, even color, retaining its vividness for an unusually long time after being cut. It is a remarkable bloomer, popular Rose. It has no characteristics which make it distinct from Radiance except that it is a light shell-pink. A grand Rose, always in bloom.

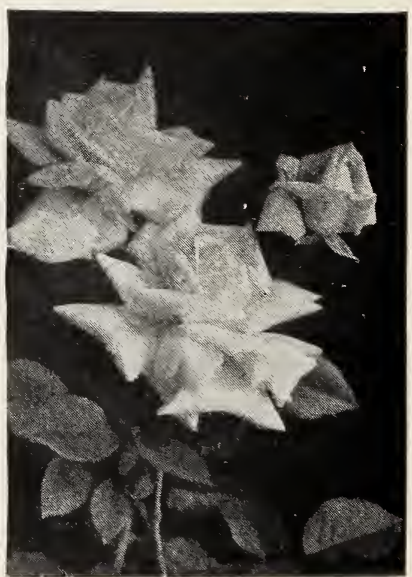

Winnie Davis Roses. 


\section{ROSES-Continued.}

RED I.A FRANCE ( $H$. T.) Much darker color than the old La France, also stronger and more vigorous grower.

RED LETTFR DAY. (H. T.) An exceedingly beautiful Rose of infinite grace and charm. Its velvety, brillant glowing scarlet-crimson buds and fully opened cactus-like flowers never fade, as the reflex of the petals ls satinedal, N. R. S.

RHEA REID. (H. T.) Flower large and double; rich dark velvety red: den Rose.

SAFRANO. (T.) Apricot-yellow, changing to orangefawn with reverse of petals tinted flesh-pink. Good grow. er. Spreading habit.

SIR THOMAS LIPTON. (R.) The best pure white Rugosa
Rose. Strong and vigorous; Rose. Strong and vigorous; ers perfectly double, pure snow-white.

SNOWFTAKE. (T.) P $\mathrm{P} r$ creamy white. Always a Vigorous grower of spreading nabit.

SOMBREUIL. (T.) Large, full flowers of white with delicate salmon shadings. Vigorous, upright habit.

SUNBURST. (H. T.) $\mathrm{L}$ o $\mathrm{ng}$, pointed buds of richest cop pery yellow,

WILLIAMI R. SMITH. (T.) Exquisite blendings of soft pinks and cream tints. Full, well-formed flowers. Worthy a place in best selected gar-
dens. Rank grower of tall,

WINNIE DAVIS. ( $T$.) Soft apricot-pink shading to flesh tints. Very double, resembling a camellia when open. Splendid bioomer and vigorous grower. Ta:l, sprea.ding habit.

\section{Climbing Everblooming Roses}

This selection of Climbers is everblooming, like the Teas and Hybrid Teas in the bush class. They produce fine flowers for cutting, are strong, vigorous growers, giving good results planted around porches, trained on small trellises or even as a yard Rose without support,
if kept severely pruned.

CHROMATELLA. (N.) Sometimes called Pillar of Gold. One of our best yellow climbers. Clear, deep ye!low, with sulphur edgings.

CL. BABY RAMBLER. (Poly.) An everblooming true Crimson Rambler. Foliage never mildews.

CL. CAROLINE TESTOUT. (Cl. T.) Vigorous climber, producing an abundance of large, cup-shaped blooms of most beautiful delicate pink.

CI. CLOTHILE SOUPERT. (Cl. Poly.) White with delicate flesh tones. Very double and most fiagrant. Blooms in clusters.

CL. DEVONIENSIS. ( $\mathrm{Cl}$. T.) Whito tinged with the most delicate pind. Exqu'sitely beautiful long pointe:]
buds surrounded by beautiful foliage. Strong climber.

CL. ETOILE DE FRANCE. (Cl.' H. T.) Identical wit the famous bush Rose of this name, but a vigorous climber.

CL. GRUSS AN TEPLITZ. (H. Ch.) An exact counterpart of the bush form of that superb Rose, Gruss an Teplitz, except that it is a vigorous climber.

JAMES SPRUNT. (Cl. Bengal). Deep cherry-red, CL. K. A. VICTORIA. (H. T.) Beautiful, large, douCL. K. A. VICTORIA. remarkable substance.

CL. KILI.ARNEY. (Cl. H. T.) An exact counterpart of Killarney in every respect except that it is a vigorous climber; deep shell-pink.

CL. LIBERTY. (Cl. H. T.) Brilliant velvety crimson: CL. PAUL NEYRON. (Cl. H. N.) Clear satiny rose; large, beautiful flowers; few thorns; good climber CL. PERLE JES JARDINS. (Cl. T.) Color deep golden vellow: one of the best climbers.

MARECHAL NIEI, (Yellow). (Cl. N.) The grand old southern favorite, 'with a fragrance equaled by none. Full, double, golden yellow, produced abundantly all seasons of the year. Positively every home should have one or more of these grand climbers these than for all other climbers combined.
PAUL'S SCARLE'. (H. W.) Vivid scarlet, shaded crimson; makes a brilliant display for a long period of time in the garden. A wonderful new climbing Rose. Received the gold medal and cup for the best new climber at the National Rose Society's exhibit.
REINE MARIE HENRIETTA. (Cl. T.) Bright cherryred. Fine buds opening into large, delicately scented blooms.

REVE D'OR. (Cl. N.) Deep coppery-yellow, fragrant blooms. One of the thriftiest of yellow climbers.

SOLFATARE. (cl. N.) Fine clear sulphur-yellow; very fine, large, shapely bud, with full double open flower.
An old favorite climber.

SUNBURST. (Cl. H. T.) A climbing sport of that peer of yellow Roses, Sunburst, the much sought new French Rose. A true pillar Rose of strong growth, bearing freely, very large cadmiumyellow flowers. Beautifu either in bud or open.

RHEA REID. ( $\mathrm{Cl}, \underset{\text { H. }}{\mathrm{H}}$ T.) Richest deep crimson
aginable; fine grower.

TAUSENDSCHOEN. ( $\mathrm{H} . \mathrm{M}$.) The flowers upon first opening are the most delicate a Rose, might be described as a white. delicately flushed pink, changing to rosy carmink, It gets its name from its many flowers and the its many flowers and the variation in coloring; will become as famous as Crimson
Rambler or Norothy Perkins.

ZELIA PRADEL. (N.) Dainty pure white buds borne in clusters. Delicately fragrant.
Half climbing. Old favorite.

\section{Climbing Rambler Type of Roses}

Much used in the North on account of their hardiness. Are valuable in the South, where rampant climbers are wanted. The flowers in the Spring are gorgecus.

BANKSIA. White. A rank-growing, thornless, oldfashioned Rose. Blooms very early in the Spring. Flowers double, small but produced in great clusters. CHEROKEE. White. (Rosa Laevigata). The wel known Cherokee of the South. A vigorous and rampant climber. Large, single, white, fragrant flowers produced in early Spring in great profusion evergreen; foliage bright, glossy green.

CHEROKEE. Pink or Anemone. Flowers same as White Cherokee except that the color is glowing pink. They resemble huge apple blossoms. Red or Ramona. Similar to Pink Cherokee but flowers darker, some of the blooms are a deep, rich cherry carmine while some may be rich pink. On older plants the flowers run darker.
DR. VAN FLEET. (H. W.) Rank climber, with the R. VAN FLEET. (H. W.) Rank climber, with the
glossy Wichuraiana foliage. Flowers a remarkable glossy Wichuraiana foliage. Flowers a remarkable to rose-flesh in the center; large and double. 1909). (H. W.) Intense crimson-scarlet, double flowers in brilliant clusters set in glossy, shining foliage which never mildews nor spots.

GARDENIA. ( $H$. W.) Bright yellow, opening cream early flowering; fragrant and free. Called the "Hardy Marechal Niel," Rank climber; thick, glossy foliage LADY GAY. (H. W.) Cherry-pink, fading to soft white. Blooms profusely in early Spring. Flowers borne in large, loose trusses, often twenty or more

perfect buds and open blooms on one stem.
MANDA'S TRIUMPH. (H. W.) Pure white, well formed, double flowers in clusters; sweetly scented;

an entirely hardy c'imber or trailer.
SILVER MOON. (H. W.) Clear silvery white with a mass of bright ye.'ow stamens, good foliage and a vigorous climber.

I am glad to report every Sarasota, I am glad to report every one of my roses is that will be open at the sanie time. Several have remarked on the fine strong plants I recelved for remarked on the fine strong plants I recelved for
my rose bed.

I got some roses from you a few weeks ago and am so well pleased with the stock that I wish to get a little other stock of you and wish you to select it for me.

A. L. MILLER. 


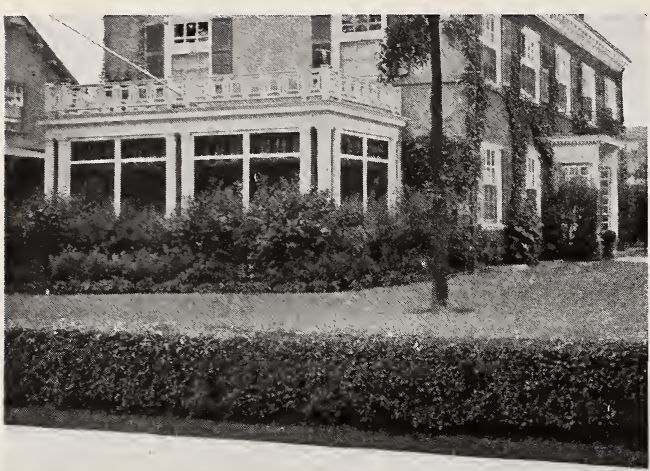

Such Homes are Always Attractive.

\begin{tabular}{|c|c|c|c|c|}
\hline & & Each & $\begin{array}{r}10 \\
83\end{array}$ & 100 \\
\hline to 24 & in & .60 & 5.00 & $\mathbf{4 0 . 0 0}$ \\
\hline & & 1.00 & 9.00 & 85.00 \\
\hline $\begin{array}{l}0 \quad 4 \\
0\end{array}$ & feet & 1.25 & 11.00 & 100.00 \\
\hline & & 1.75 & 15.00 & \\
\hline
\end{tabular}

B\&B at double above prices.

ALTHEA, or ROSE OF SHARON (Hibiscus Syriacus) Well known free-blooming, upright shrub, bloom-
ing in late Summer when other plants have ceased.

Amplissima. Double; deep purple-pink, with carmine center; tall growing.

Boule de Feu. Double red.

Jeanne d'Arc. Double, pure white.

Peoniaeflora. White, with cherry-red center.

Rosea. Mixed co'ors; fine for hedges and massing.

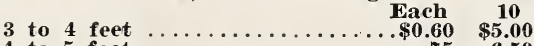

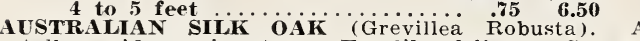
tall, rapid-growing tree. Fernlike foliage. Can be topped to control height. Hardy as the orange trees; an excellent pot plant.

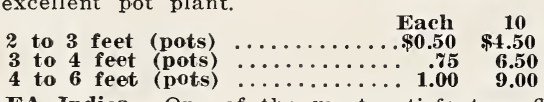

AZALEA Indica. One of the most satisfactory flowering evergreen shrubs for the lower South, where it is a mass of gorgeous flowers in Winter and early Spring. To get the best results, Azaleas should be planied in a somewhat shaded situation, especialiy where they are protected from the hot afternoon sun of Summer. The best soil is one containing an aburdance of leaf mold, peat and sand, but soil should be well drained. Azaleas will not succeed in limestone or alkali soils. The plants must be kept well mulched with rotted leaves. Can supply following colors: Variegated, lavender, pink, white

$\mathbf{8}$ to 12 in. B\&B $\mathbf{\$ 1 . 0 0} \$ \mathbf{9 . 0 0}$
and pink. 8 to 12 in. B\&B $\$ 1.00 \quad \$ 9.00$
12 to 15 in. $B \& B$ 1.50 $\begin{array}{lll}12 & \text { to } 15 \text { in. B\&B } 1.50 \\ 15 & \text { to } 24 \text { in. B\&B } 2.50\end{array}$

BACCHARIS Halimifolia (Salt Bush). A perfectly hardy native shrub of good growth and habit. Gray-green foliage. During late Fall the cloudy mass of white down used by nature for transporting seeds makes the bush a beautiful sight.

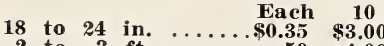
2 to 3 ft...... $.50 .35 \$ 3.00$

\footnotetext{
Stark, Fla. Dec. 12,1924 Shipment of trees received on $10 \mathrm{th}$. Everything in good condition and the nicest lot of nursery stock I ever saw.

FRED CARLTON.
}

\section{Evergreen and}

Under this broad classification come the Broadleaf Evergreens, so numerous and valuakle in the landscape plantings of the South, and also the gorgeous flowering shrubs which lose their foliage in Winter (deciduous). Evergreens should predominate in southern plantings, where the winters are mild and lawns look as beautiful in Winter as in Summer.

We especialiy call your attention to the Broad-leaf Evergreens, this class having received our closest types being brought to the front and others introduced through our efforts.

To relieve the monotony of green tones, there should be a generous use made of the beautiful flowering plants we have selected and which do so well in the South.

ABELIA Grandiflora. A hardy, free-blooming shrul with shiny, purplish, evergreen leaves; bears a profusion of clusters of tubular-shaped flowers about one inch long, white inside. Fragrant blooms last all summer. Very desirable. Trained for banking and foundation planting.

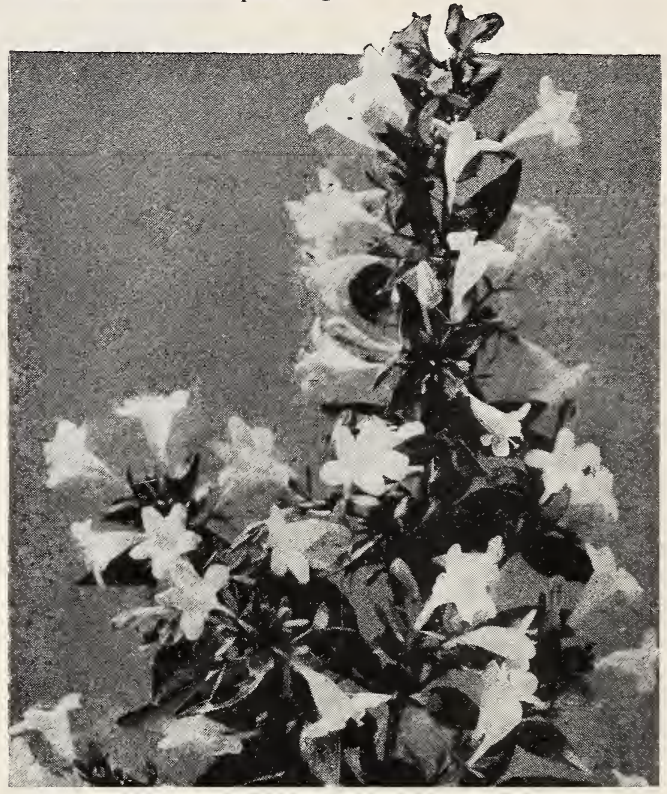

Abelia Grandiflora.

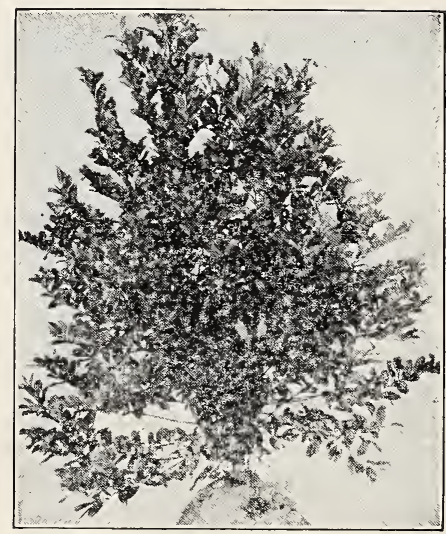

Laurel, Southern or Cherry.
BOTTLE BRUSH SHRUB (Callistemon rigidus). Particularly interesting shrub with long, narrow leaves and dense spikes of deep red flowers, taking the form of a bottle brush. Stands shearing.

Strong plants: $\quad$ Each
4-inch pots $\stackrel{10}{10}$

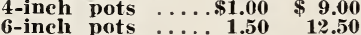

CAMELLIA Japonica. Well known Winter flowering evergreen
shrub, commonly called Japonica. Leaves large, dark green and glossy; waxy, double flowand glossy; waxy, double flowers, suggesting the full biown Red, pink and variegated. 1-year plants, potted or $\$$ B\&B.......... 2 -year plants, potted or Wherever you find this mark BSB it stands for Balled and Burlapped, meaning the roots are dug
with firm ball of earth and securely wrapped in burlap. We always reconimend such stock balled.
it assures stock living as well as inmediate effect. Foliage retained. Quicker and better results. 


\section{Deciduous Shrubs}

CAMPHOR, Busl Form (Cinnamomum Camphora). Exceedingly beautiful shrub. Can be kept in beautifully trimmed hedge less than two feet high, or allowed to make a bushy shrub twenty feet or more in height. Glistening foliage in light and dark shades of green, produced by young and old leaves. In Fall, a few leaves turn brilliantly crimson. New growth is wine colored, passing through all tones to its is wine allu it dark green shade. Allowed to grow naturally, it makes a perfect broadiy rounded cone, bushy clear to the ground, very compact. For natura phor is the most perfect plant. Fine specimens for lawns, also.

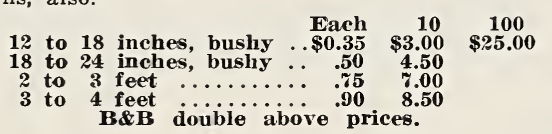
CAPE JASMINE (Gardenia Grandiflora). The old
southern favorite, with glossy leaves and masses of waxy white flowers; very fragrant. Attains excellent height for foundation planting, massing and fort height for foundation planting, massing and characteristic plant of the South. Blossoms highly valued in the North, where it is known as the valued in the North, where it is known as the so freely.

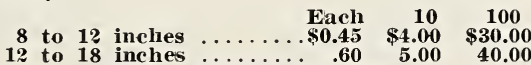
B\&B double above prices.

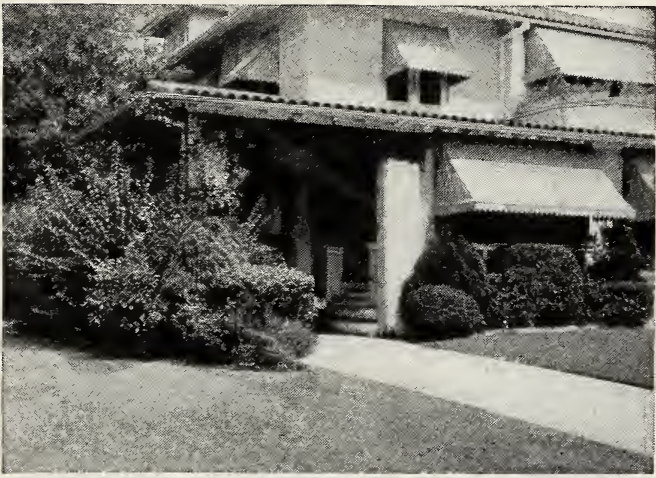

Entrance Planting.

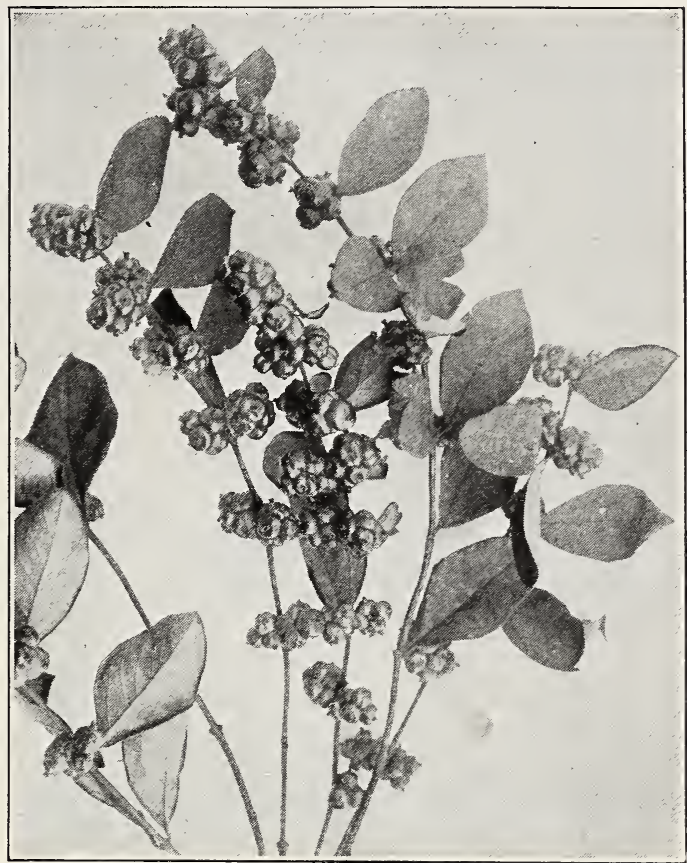

Coralberry or Indian Currant.

CAPE JASMINE, Everblooning (Gardenia Florida) An improved strain of the well known Cape Jasmine or Gardenia Grandiflora. Blooms more or less the entire season, instead of Spring only. Smaller blossoms, but very fragrant.

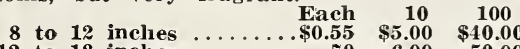

12 to 18 inches ........ .70 $\mathbf{6 . 0 0} \mathbf{5 0 . 0 0}$

CASSIA Floribunda. A free-blooming plant. Large orange-yellow, pea-shaped flowers, produced in great profusion from midsummer until winter. Height 6 8 feet. A most effective law

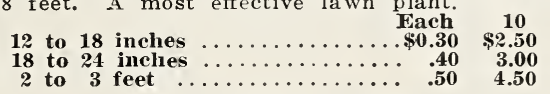

CESTRUM Diurnum (Day-Bloom. ing Jasmine). A quick-growing shrub of upright habit, dark green glossy foliage Produces quantities of small tubular, white flowers. Blossoms attractive for cut flowers.

CESTRUM Nocturnum ( $\mathrm{Ni}^{\mathrm{i}} \mathrm{h}$ tBlooming Jasmine). Large, rank-growing shrub with greenish colored flowers opening about sunset and emitting a very heavy fragrance. Blooms at intervals through the year. Blooming Jasmine:

Small plants $\quad \begin{array}{cc}\text { Each } & 10 \\ \$ \$ \$ 0.50 & \$ 4.50\end{array}$ Iedium plants. $.95 \quad 6.50$

CRATAEGUS Pyracanthus (Burning Bush). Broad-leaf evergreen masses of white flowers early in spring, and orange-red berries in Autumn and Winter. Good for massing or specimens. Handled only B\&B.

1 to 2 feet B\&B ... Fach 2 to 3 feet $\mathbf{B \& B} \cdots \cdots, 2.50$

D $R$ Wherever you find this mark $B \& B$ it stands for Balled and Burlapped, meaning the roots are dug Gentlemen:-I enclose check for $\$ 11.15$ to pay invoice of thanks for sending such nice Yours very truly. W. L. HALL. 


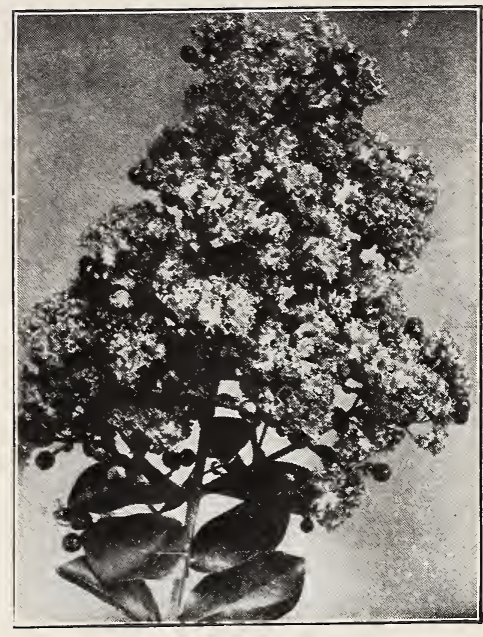

Crape Myrtle Blossom.

\section{CRAPE MYRTLE - Lagerstroemia Indica}

The favorite flowering shrub of the South; hardy and heavy bloomer. Frequently termed the "Lilac of the South." There are two main types, the large or common strain, and the dwarf. The former can be grown in either large shrub or small tree form. The dwarf forms are usually less than six feet in maturity and can be kept as low as desired by annual trimming as the flowers lade.

\section{LARGE OR COMMON TYPE.}

Attaining 20 feet. We can supply this class in both bush and tree form. Crimson, light pink, white and purple colors.

DWARF CRIMSON. One of the most popular shrubs with our trade. Rich crimson color characterizes the blossoms, which are borne in exceptionally large, fluffy heads often 10 inches long by 8 inches across. This new type should be widely planted. Very unusual color, seen in no other Crape Myrtle. A true dwarf. Of all flowering shrubs, this is the most desirable in the South. It adds life, with its gorgeous colored, large flowers, for a long time in Summer and early Fall. Foliage is very handsome. Sometimes called Watermelon Pink.

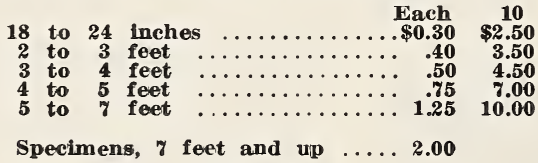

\section{DEUTZIA}

One of the most desirable shrubs. Their hardiness, juxuriant foliage, and profusion of attractive flowers render them deservedly among the most popular of dowering shrubs. They are extremely florlferous and ornamental and make possible many striking effects in garden or border plantations.

Candidissima (Double White Deutzia). A tal! shrub, attaining 5 to 6 feet, with numerous upright branches. A handsome, free-flowering shrub; blooms very A han

Crenata (Single White Deutzia). Flowers pure white and produced in great profusion very early in the Spring. A tall, thrifty grower.

Pride of Rochester. Tall-growing shrub, blooming first of April. Double white blooms with back of petals pink. Deserves a place on all grounds.

\begin{tabular}{|c|}
\hline $\begin{array}{llll}2 & \text { to } & 3 & \text { feet } \\
3 & \text { to } & 4 & \text { feet } \\
4 & \text { to } & 5 & \text { feet }\end{array}$ \\
\hline
\end{tabular}

\section{ELEAGNUS - Oleaster}

Should be used planting and kept pruned to any size wanted reely for all group planting and We cannot too highly recommend

Pungens. A very handsome form of this type, with leaves 3 to 4 inches long, very dark green above and silvery beneath, with lowers, in January, are creamy white and fragrant.

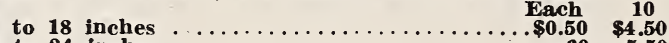

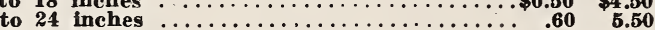
Produces fruit same as Aurea Maculata.

the type, up to 6 feet high, with brown branches and green leaves beautifully blotched with golden yellow.

rice, Pungens Variegata and Pungens Aurea Maculata:

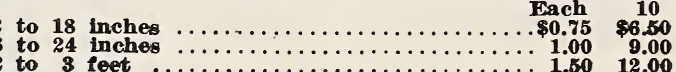

Reflexa (Climbing Elleagnus). A remarkably vigorous this will make a vigorous vine, though by pruning it

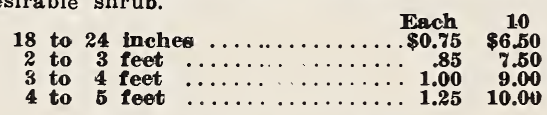

$B \& B$ at double above prices.

While our prices are as low as any, yet our alm is not to be the cheapest: value is our big consideration and aim. Constant care bestowed upon sideration and ain. tirees in bringing them the the best nurtured cond. tion malkes for cost. Wo could reduce nurturin cost and consequently selling costs, but that would not be giving Quality and Value. Ihe best Value for the Money-that is our desire.

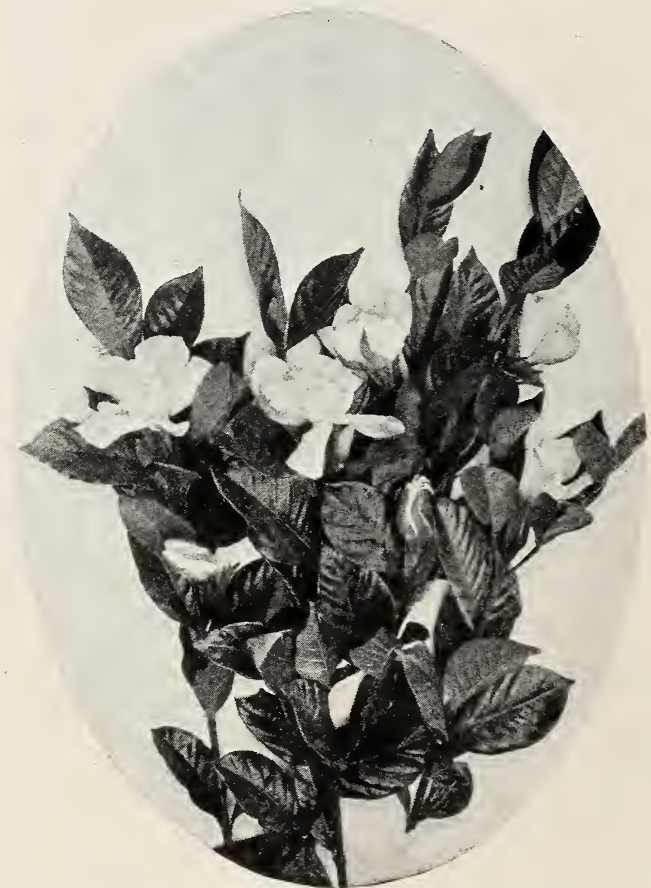

Gardenia Florida or Cape Jasmine in Flower. 


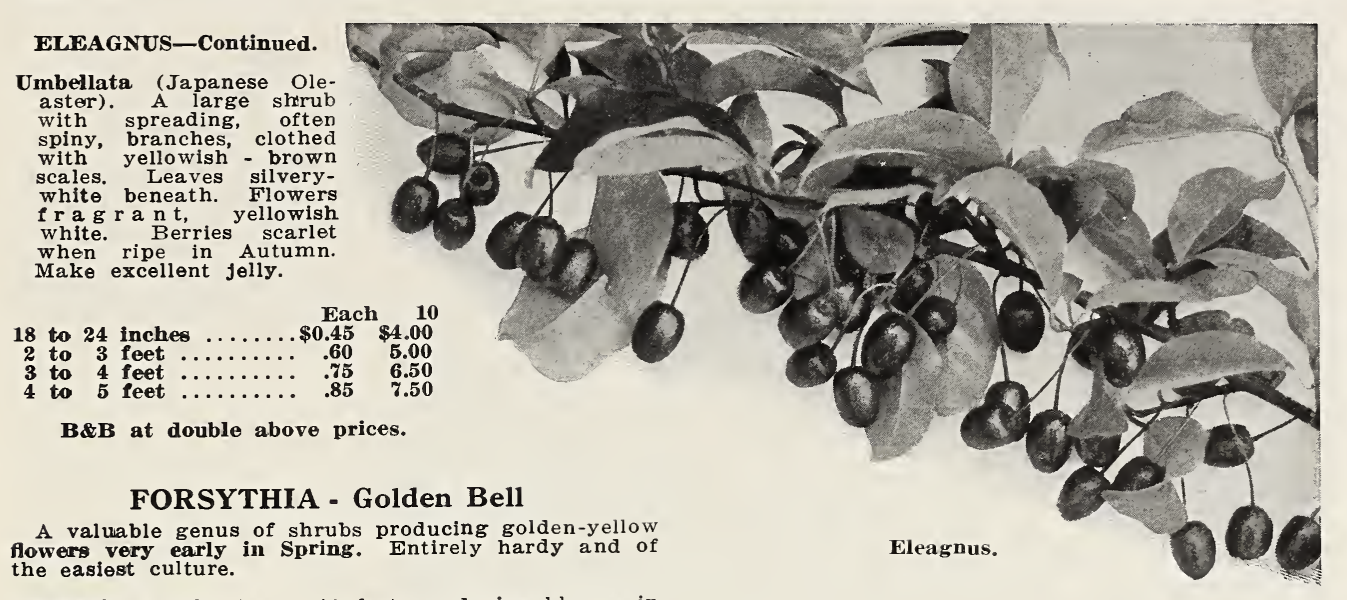

Fortunei. Shrub of 8 to 10 feet, producing blooms in March.

Intermedia (Hybrid Golden Bell). A tall variety with slender arching branches. Flowers in great profusion. Attains 8 to 10 feet. Blooms early.

Suspensa (Drooping Golden Bell). A graceful variety with long, slender, drooping branches. Leaves dark, shining green. Blooms in March or earlier.

Viridissima. Profusion of blooms very early in Spring, often in February.

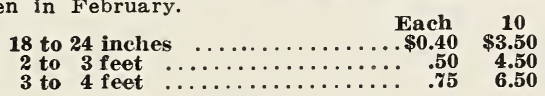

\section{HIBISCUS ROSA - SINENSIS}

(Chinese Hibiscus). Semi-hardy shrub with glossy green foliage and large, showy flowers. Freezes, but comes up from roots, blooming in sict time.

$$
\begin{aligned}
& \text { Small plants, Pot or B\&B } \ldots \ldots \ldots \text { Each } 10 \\
& \text { Large plants, Pot or B\&B .........75 } \mathbf{6 . 5 0} \\
& \text { Extra large plants, Pot or B } \& \dot{B} \ldots \ldots
\end{aligned}
$$

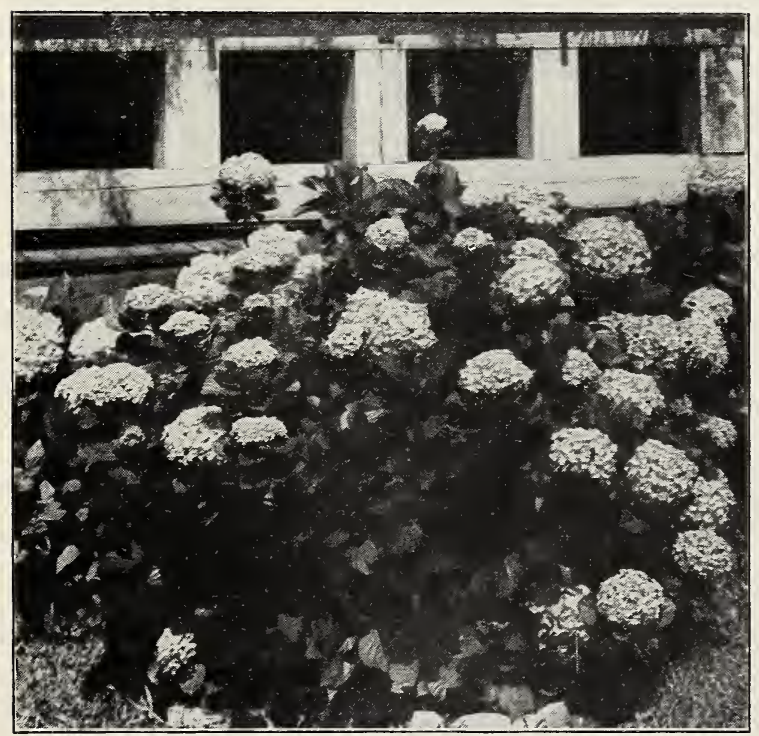

Hydrangea.

\section{HYDRANGEA}

Nearly evergreen in extreme South. Large, dark green, glossy leaves. Giant flower heads in various shades from pure white to deep pinks and blues, produced in great profusion in the Spring and lasting nearly all Summer.

HORTENSIS AND OTAKSA. Beautiful large heads, varying from pink to blue according to soil condi-
tions.

THOMAs HOGG. Pure white.

\section{FRENCH VARIETIES.}

A new importation of assorted colors, pink, blue and white; giant heads. Grand shrubs for the South. Do best on north side of buildings or should be given partial shade.

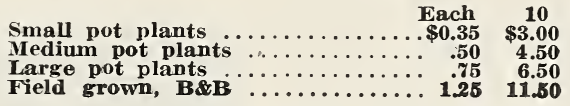

\section{ILEX GLABRA - Inkberry}

Handsome exergreen shrub with bright, shiny roundish leaves; grows well in any kind of soil and tends to spread and thicken. Very desirable for banking and mass planting.

2 to 3 feet, bushy $\ldots \ldots \ldots \quad \underset{0.50}{\text { Each }} \$ 4.50$

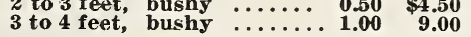

ILEX MYRTFOLIA (Myrtle-Leaf Holly). Evergreen shrub of good height, no spines, foliage resembles myrtle, 1 to 2 inches long. Fruit dull red, borne singly.

$$
\begin{aligned}
& 2 \text { to } 3 \text { feet } \ldots \ldots \ldots \ldots \ldots \ldots \quad \underset{0.65}{\$ 6.00}
\end{aligned}
$$

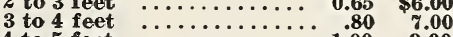

$$
\begin{aligned}
& 4 \text { to } 5 \text { feet } \ldots \ldots \ldots \ldots \ldots \ldots 1.00 \quad 9.00 \\
& 5 \text { to } 7 \text { feet } \ldots \ldots \ldots \ldots \ldots \ldots \ldots .1 .25 \quad 11.00 \\
& \text { B\&B at double above prices. }
\end{aligned}
$$

\section{ILLICIUM - Anisatum}

EAST INDIAN ANISE. (H. Japan). A handsome, broad-leafed, evergreen shrub of large size, 10 to 12 feet high, about as hardy as the Camellia. The aromatic foliage is fragrant when bruised. One of the very finest of all border shrubs as far as follage values are concerned.

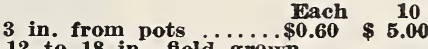

$$
\begin{aligned}
& 12 \text { to } 18 \text { in., field grown }
\end{aligned}
$$

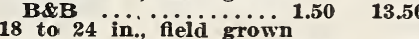

$$
\begin{aligned}
& \text { B\&B } \ldots . . \ldots \ldots \ldots 2.00 \quad 17.50
\end{aligned}
$$

R $R$ Wherever you find this mark B\&B it stands for Balled and Burlapped, meaning the roots are dug with firm ball of earth and securely wrapped in burlap. We always recommend such stock balled.
It assures stock living as well as immediate effect. Foliage retained. Quicker and better regults. 


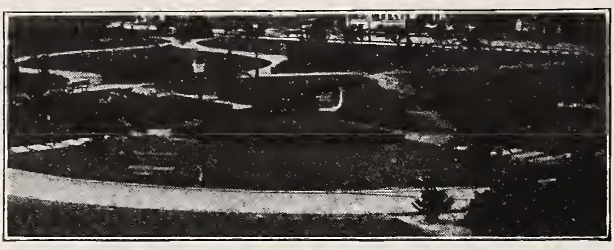

Corner in a Beautiful Park Just After Being Laid Out by Us.

\section{JASMINES or JASMINUMS}

These are among the prettiest and most valuable of our Southern evergreen shrubs.

Pubescens. Beautiful light-colored pinnate foliage; very thrifty; hardy in lower South. Desirable for borders, beds and porch-boxes. Can be trained as shrub or climber. The star-shaped, waxy white, fragrant flowers produced in abundance nearly all the year.

Sambac. Large, flat, fragrant flowers. Is equally good as shrub or climber. Requires protection from frost north of extreme South and Gulf Coast section. The beauty and fragrance of its flowers once known can
never be forgotten. Two varieties, Grand Duke, never be forgotten. Two varieti
double; Maid of Orleans, single.

Prices of Jasmine Pubescens and Sambac: Pot plants, 6-inch pots..........\$0.75

Humile. Evergreen in the lower South. Hardy north to Maryland. Leaves dark green; flowers bright yellow, produced in open clusters almost continually throughout the Summer.

Primulinum, or Italian Jasmine. Beautiful shrub with green stems and attractive foliage; blooms early in Spring; hardy. Blooms in long sprays of scented, beautiful golden-yellow flowers as large as a half dollar. An exceedingly valuable trailing shrub. Can be trained on trellis.

12 to 18 inches, each, 35c per 10, $\$ 3.00$.

18 to 24 inches, each, $50 \mathrm{c}$; per 10, \$4.50.

2 to 3 feet, each, 85c; per $10, \$ 7.50$.

3 to 4 feet, each, $\$ 1.15$; per 10, \$10.00.

$\mathrm{B \& B}$ at double above prices.

\section{LAUREL, Southern}

(Prunus Caroliniana)

Cherry Laurel and Wild Peach are other names for this plant. One of greens. Foliage is exgreens. Foliage is exvery rich green color. Naturally compact and symmetrical in form, it submits to shearing and can be kept in any form and at any height. As a large shrub in foundation planting, or in groups, masses, borders, or screens, it has no superior. White flowers in Spring. Very hardy and abuse.

18 to 24 inches, bushy, each, $\$ 0.75 ; \quad 10, \$ 6.50$ $100, \$ 55.00$.

2 to 3 feet, bushy, each, $\$ 0.80 ; 10$, \$r.50; 100 $\$ 65.00$.

3 to 4 feet, bushy, each, $\$ 1.00 ; \quad 10, \$ 9.00 ; \quad 100$, $\$ 80.00$.

B\&B at double above prices.

\section{Ligustrums}

GRIFIING'S SOUTHERN SELECTION.

The Most Popular Broad-Leaf Evergreens.

A group essential to landscaping. The word, "Ligustrum" (L), refers to a large family of plants whose individual members are widely different in their variou characters. The group is by far the largest and most generally successful among our broad-leaf evergreens. Individually and as a group, their beauty is unrivalled. All of the Ligustrums are valuable for ornamental plantng because of rich coloring; clean habit; vigorous, ealthy nature. Panicles of fragrant white blossoms are borne profusely in Spring, followed by showy fruits in shades of purple resembling wild grapes.

Our early recognition of the beauty and importance of this great group caused us to devote the closest attention to the observation, selection, and development of the various types, and, with recent introductions we have made, together with those contemplated for the future, we have observed the need for a simple classification of the pronounced types for the convenience of our trade, and with the idea of encouraging greater familiarity with the new varieties among the many people who have learned the beauty and value of this group in their landscape and ornamental planting, we have prepared the following classiflcation based on very broad principles.

\section{We Stand Back of Our Plants at All Times}

The greatest care is exercised to have the plants true to label, and we hold ourselves prepared to refund the purchase price or replace on proper proof all that are untrue to name. We do not give any warranty, express or implied, and in case of any error on our part it is mutually agreed between the purchaser and ourselves that we shall not, at any time, be held responsible for a greater amount than the original price of the goods.

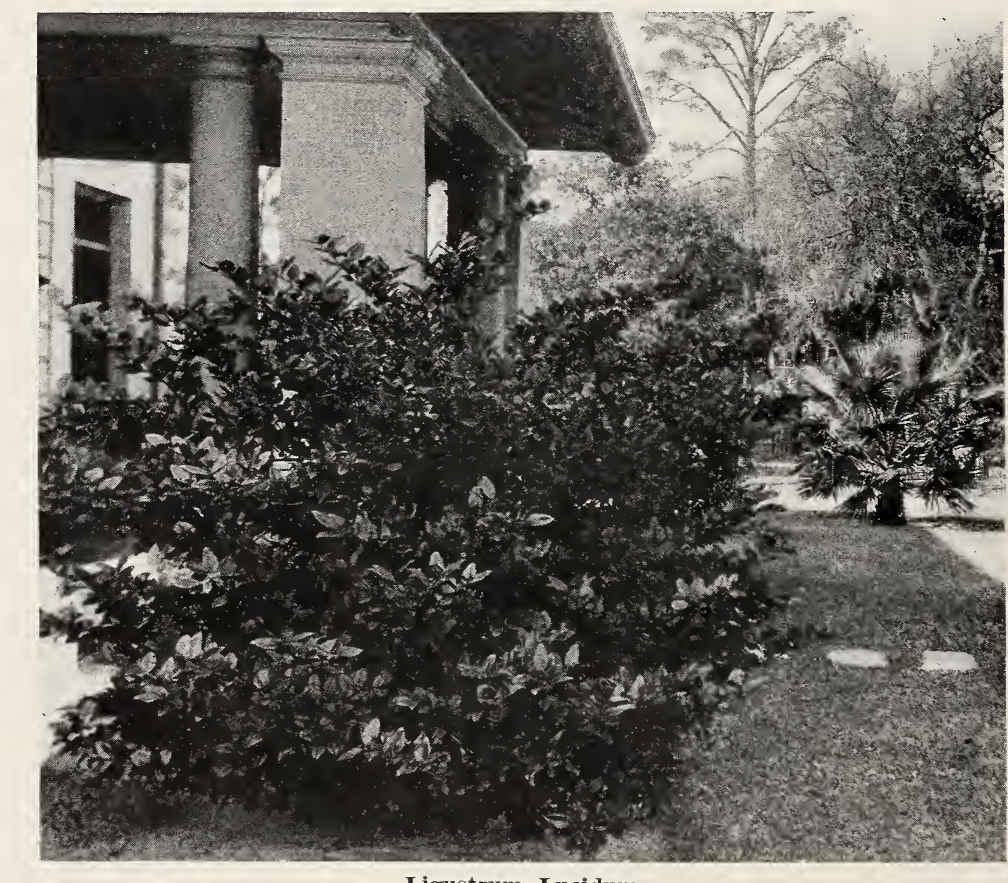

Ligustrum Lucidum.

R 8 Wherever you find this mark B\&B it stands for Balled and Burlapped, meaning the roots are dug with firm ball of earth and securely wrapped in burlap. We always recommend such stock balled.
It assures stock living as well as immediate effect. Foliage retained. Quicker and better results. 


\section{LIGUSTRUM-Continued.}

THICK GLOSSY LEAI TYPE (Lucidums).

The glossy leaf type is marked in having very glcssy or shiny foliage of shading from almost black in some varieties to a light mottled effect in others. Height varies from low to tall and nature of growth is widely different in various varieties. This is probably the most distinctive type and has the highest quality and best texture in the family.

Griffing's Wax. The finest of all Ligustrums. Selected from among many thousands of imported Japanese plants, carefully preserved and kept to itself, we have developed the high:y improved strain until it is a class all alone. In appearance it has the finest quality of any broad-leaf evergreen, and is exceed-

ingly hardy and resistant to abuse. The foliage is deep rich green, almost black. The leaves are very thick, beautifully shaped, and glisten as though polished. In its growth, this plant is very compact, dense and wide spreading, keeping greater width than height ordinarily. It is uniform in deve'opment, maintaining a symmetrical form naturally. it permits pruning and trimming to any desired st permits pruning and when longer tips are pinched back, it increases its appearance. For permanent beauty, increases its appearance. For permanent beauty, we unreservedly recommenth windows, at entrances, foundation planting, beneath windows, at entrances, to mark property lines and for boriering masses of high-growing shrubs. Will mal

Iwata or Variegated Nepalense. Characterized by mcttled shades of light yellowish green in center of leaves: this rather compact, low-growing Lucidum is deserving of a place in every planting. Leaves are small, thick, very shiny. Maintains a widein front of Grifling's Wax.

Lucidum. Leaves large, thick, lanceolate, of a very dark shining green. Hardy at Baltimore. Resembles Griffing's Wax but more open growth anc leaves farther apart on stems.

Nepalense. Medium size, dark green, glossy leaves; uniform, compact spreaaing growth. A very at tractive plant, essential to landscape planting in masses, banking or groups. Fills space between rank growing shrubs and the very low growing rank growing shrubs and the viant in front of Griffing's Wax.

Prices: 2-3 year trained bushy specimens.

$$
\text { Each } 10 \quad 100
$$

$11 / 2$ to 2 ft. high, $11 / 2-\$ 2.00 \quad \$ 19.00 \quad \$ 175.00$ $\begin{array}{lllll}2 & \text { to } 3 & \text { ft. high, about } & & \\ 2 & \end{array}$ $\begin{array}{lllll}2 \text { ft. spread B\&B .. } & 2.50 & 22.50 & 200.00 \\ 3 \text { to } 4 \text { ft. high, about } & 3.50 & 32.50 & 300.00\end{array}$ $\begin{array}{lllll}21 / 2 & \mathrm{ft} \text {. spread B\&B } & 3.50 & 32.50 & 300.00\end{array}$ B\&B ............... $\$ 5.00$ to $\$ 10.00$ each

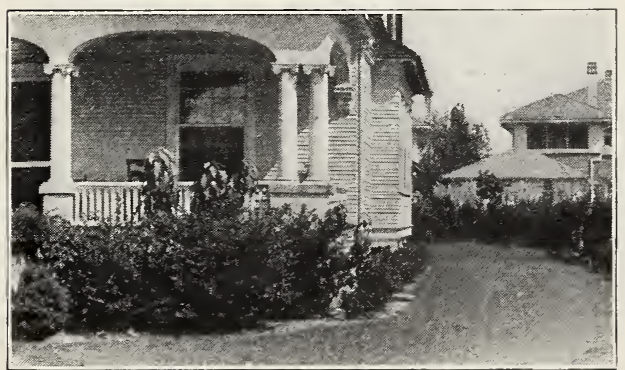

Showing Side and Backyard Planting.

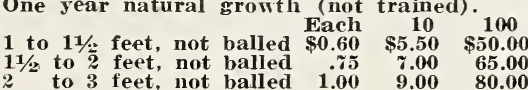

Gracilis. A distinctive graceful variety which we have propagated from a seedling discovered in our nurseries in mature development it has spreading. upright growth with long branches recurving gracefully with a pronounced distinction from the vertical branching of our Nobilis rariety. In height it ranks above the Grifnges $W$ ax and other smallergrowing Lucidum varieties and this controls its position in plantings. Foliage is dark green, glossy,
curled upward and distinctly pointed. Branches curled upward and distinctly

Foliis Aurea. Bright golden-edged leaves and golden young growth make this variety very valuable in landscape plantings. For massing, banking or in groups with plants of green foliage. When such groups with plants of green foliage. When such contrast is made, effect is most pleasing. It holds its leaves and puts on blue berries, making it very
attractive in Winter. Stands sun well. Use a few of these among your green foliaged evergreens for the necessary color effect.

Japonicum (Japan Privet). For a quick-growing, broad-leaf evergreen, this fills a large demand-for high massing and banking. Beautiful effect where dark green. Sturdy, upright grower.

Nobilis (Formerly called Pyramidalis). Vertical in growth. The one broad-leaf evergreen that gives good results for ligl points in a planting. Between good results for high points in a planting. Between back of lower growing plants. this tall, slender, dense, beautifully shaped plant is needed in quantity in every home planting. Include several in your in every home planting. Include several in your is large size, rich, dark green.

Prices: 2- and 3-year trained, bushy specimens.

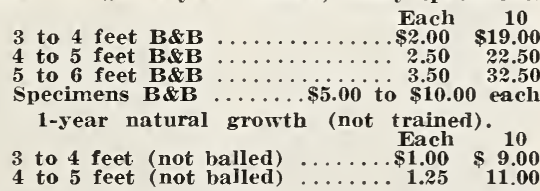

NOTE. Our trained specimen Ligustrum Lucidum. Nepalense, Wax Iwata, Nobilis, Foliis Aurea and Japonica listed herewith have all been pinched back and pruned several times during growing period, and trained to well rounded heads; every plant offered is a shapely specimen, and extremely desirable for laniscape work and formal plantings where immediate finished effect is desired. We offer these balled and burlapped only.

D 8 Wherever you find this mark $B \& B$ it stands for Balled and Burlapped, meaning the roots are dug $\mathrm{B} \& \mathrm{C}$ with frrm ball of earth and securely wranped in burlap. We always recommend such stock balled. 


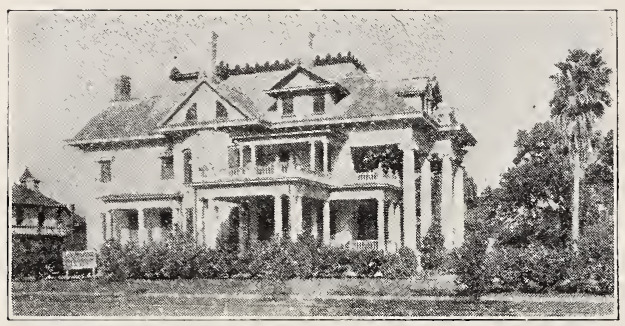

Landscaping in Course of Development.

LANTANA. Gorgeous shrubby plant from tropical America. Vigorous, luxuriant grower used for interplanting in landscape foundation and mass group; subject to freezing but comes back from ruots, making large bush in a short time. Several popular colors offered.

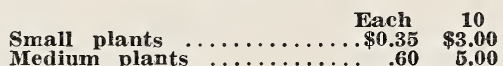

\section{LONICERA - Bush Honeysuckle}

Practically evergreen in the South. Upright bushy in habit, beautiful flowers and berries. Good for massing and banking.

Nitida. Hardy, white, blooming. Berries.

Morrowi. Strong growing; dark green foliage white flowers in April, followed by red berries.

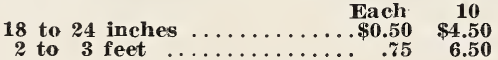

MALVAVISCUS (Turk's Cap). Will probably give an informal flowering hedge quicker than any other subject. Blooms continuously but especially during the Winter months. Will stand severe shearing, but, being broad-leaved, is best not cut back any oftener than necessary, as the cut leaves give a ragged effect until the new

\begin{tabular}{|c|c|}
\hline & Each \\
\hline $\begin{array}{l}-i n c h \text { pots } \\
\text { to } 4 \text { feet, field grown, B\&B } \\
\text { to } 5 \text { feet, ficld grown, B\&B }\end{array}$ & $\begin{array}{r}\$ 0.60 \\
\therefore \quad .75 \\
\therefore \quad 1.00\end{array}$ \\
\hline
\end{tabular}
growth comes out.

MYRICA CERIFERA (Southern Wax Myrtle). One of the most attractive native evergreens, medium to large growth. A splendid shrub for group and foundation planting. Broad, dark green foliage blending well with other plants or making a striking single specimen.

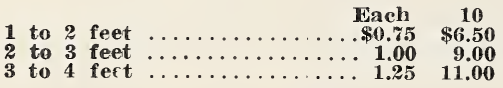

NANDINA DOMESTICA. Beautiful little evergreen, stooling method of growth. Foliage fine, pointed leaves, golden green in Spring ard Summer, turning to Autum colors. One of the best plants for color qualities. Hardy and vigorous grower. Splendid for foundation planting. White flowers in season; red berries in winter.

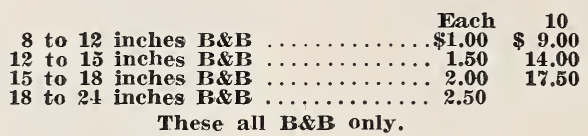

OLEANDER - Nerium

Evergreen, bearing long, narrow leaves and very brilEvergreen, bearing long, narrow leaves and very bril
liant heads of colorful blossoms, good for outside effect and beautiful for tub plants. Upright growth, good for massing and foundation planting. Unsurpassed as a lawn specimen or shrub to alternate with street trees or beautify a boulevard or park. If tops freeze back in more northern locations, it will come out from the roots with luxurious growth.

single White Single white flowers of good size in large clusters.

Double Pink. Double deep pin k; very l a $\mathrm{r} g \mathrm{e}, \mathrm{fr} e$ bloomer, best for general planting.

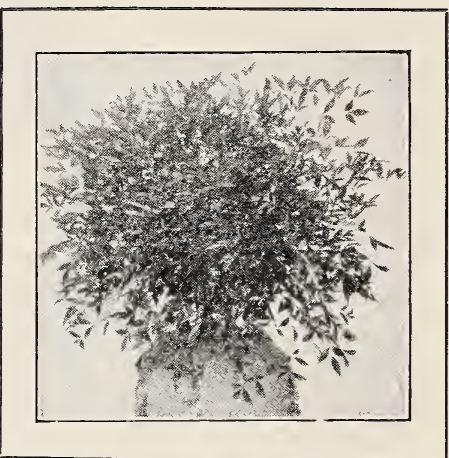

Nandina-Scarlet Winter Color.

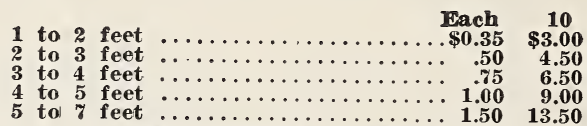

B\&B double above prices.

Fvergreens, whether in Winter or in Summer, are a permanent pleasure. A home in arett are a permanent pleasure. A home in a pretty and and comfort in Winter, and is cool appearing and as inviting a retreat in summer as the

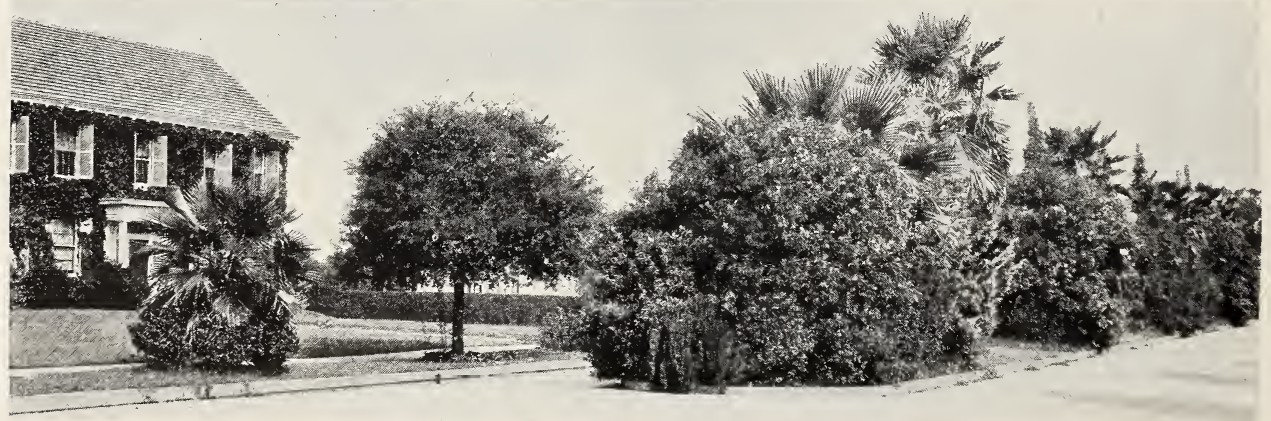

Palms Interplanted with Ligustrum and Conifers in Street Parkway.

R \& 2 Wherever you find this mark B\&B it stands for Balled and Burlapped, meaning the roots are dug with firm ball of earth and securely wrapped in burlap. We always recommend such stock balled. It assures stock living as well as immediate effect. Filliage retained. Quicker and better results. 
EVERGREEN ANU DECIDUOUS SHRUBS-Continued. SPECIAL VARIETIES OF OLEANDERS.

Atropurpureum Plenum. Double purplish crimson flower, with occasional

Dr. Goldfin. Magnificent single flower, bright deep pink (almost red); scented; opens early in the season.

Madonna Grandiflora. Pure white double, of large size, very fragrant. The best of the double whites.

Nankeen. Single yellow, of open growth. Very attractive.

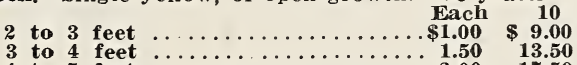
3 to 4
4 to 5
$\mathbf{5}$ B\&B at double above prices.

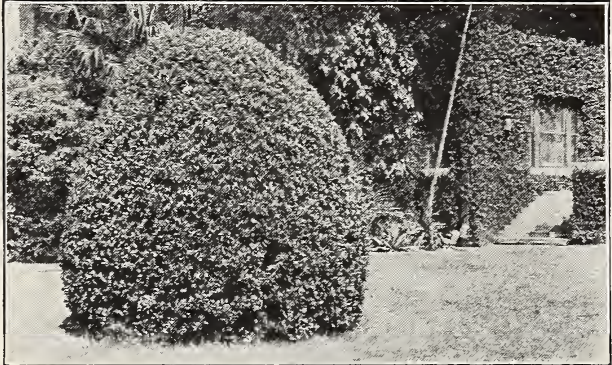

Sheared Griffing's Wax Ligustrum.

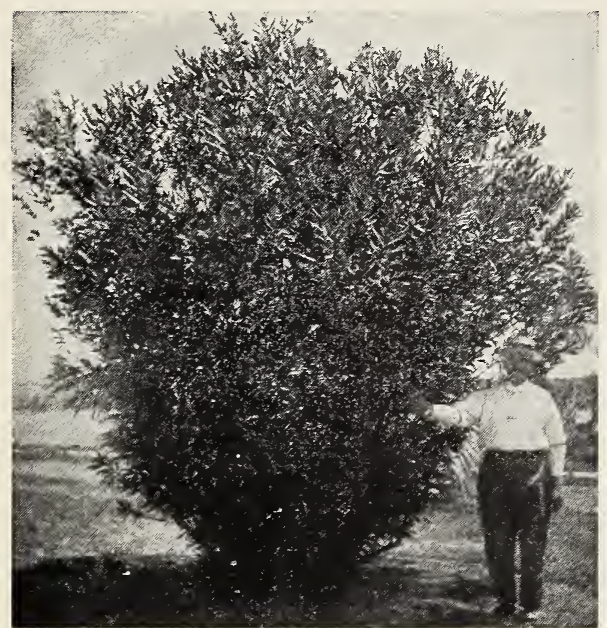

Oleander Splendens.

PLUMbago CAPENSis (Blue Leadwort). Beautiful small to medium shrub, bearing wealth of light blue, Phloxlike blossoms. For interplanting; foliage is fine, light green color. Comes up from roots if frozen back.

4-inch pot plants $\ldots \ldots \ldots \ldots . \$ 0.60 \quad \begin{array}{cc}\text { Each } & 10 \\ \$ 5.50\end{array}$

PURPLE LEAF PLUM (Prunus Pissardi; also called Thundercloud Plum). Foliage of rich effect. In massing of groups, makes large shrub or small tree. Acid fruit.

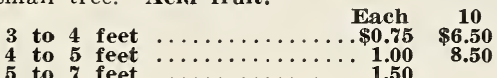

PHILADELPHUS (P. Grandiflora). (Mock Orange or Syringa). Fine old shrub with white blossoms, similar to orange blossoms, borne early in Spring.

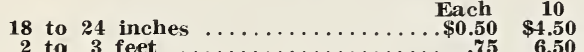

PHOTINIA SERRULATA (Dententa). Beautiful, largeleafed, hardy evergreen supplying the foliage texture of the northern Rhododendrons and English Laurels. Delightful contrast in shades of new and old foliage. the brownish red stems at tips, and the older leaves taking on brilliant crimson color in Winter. making it partic on briltiant crimson color in dense and extremely bushy.

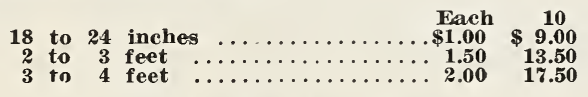

B\&B at double above prices.

PITTOSPORUM (P. Tobira). An evergreen unequaled in desirable peculiarities. Can be sheared to any desired shape or permitted to grow informally forming a very bushy, compact, wide-spreading shrub. Small creamy blossoms of delightful fragrance. For massing and foundation planting, it is one of the best. Luxurious growth Rounded form, branched clear to the ground, meeting the lawn perfectly.

Each 10

3 -incli pots, 10 to 15 inches $\ldots \ldots \ldots . \$ 0.60 \quad \$ 5.00$

4-inch pots, 15 to 18 inches $\ldots \ldots \ldots \ldots .75 \quad 6.50$

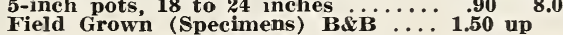

POMEGRANATE, Flowering (Punica Granatum). Very dense, bushy shrub with glossy foliage. Great abundance of colored blossoms, making very attractive mass pianting. Singles and doubles, white and red.

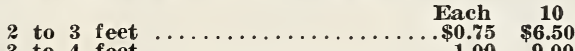

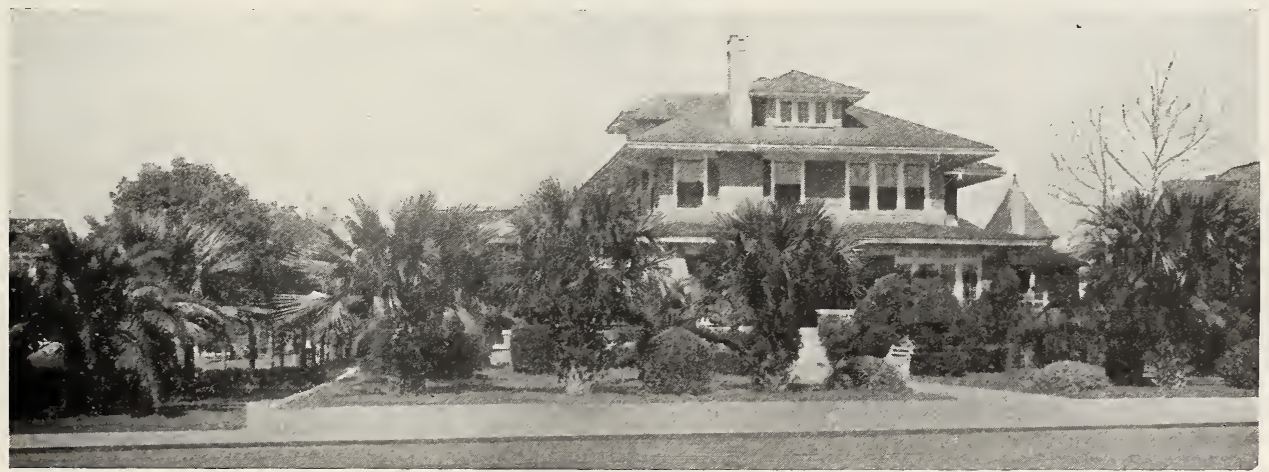

Palms in Variety. Sheared Pittosporum and Laurel Cherry.

D 9 Wherever you find this mark B\&B it stands for Balled and Burlapped, meaning the roots are dug with firm ball of earth and securely wrapped in burlap. We always recommend such stock balled. It assures stock living as well as immediate effect. Foliage retained. Quicker and better results. 


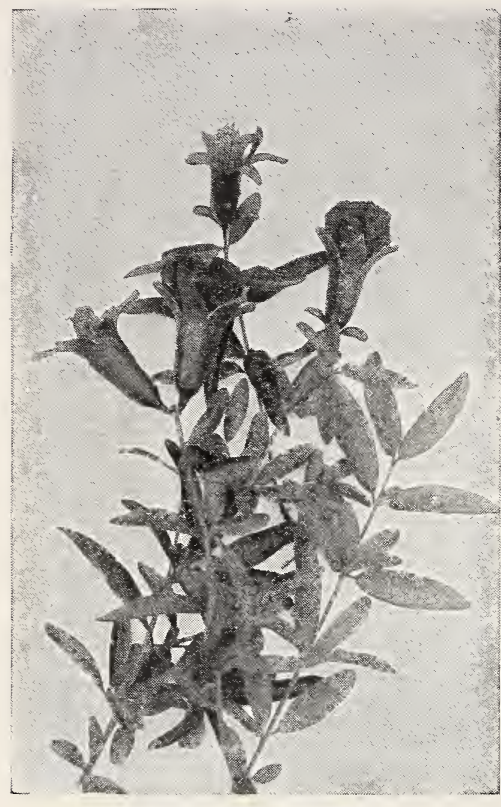

Pomegranate Blossom.

PUSSY WILLOW (Salix discolor). The beautiful glossy brown branches with fuzz covered buds are well known. To obtain a better effect, cut back after new growth comes out each year.

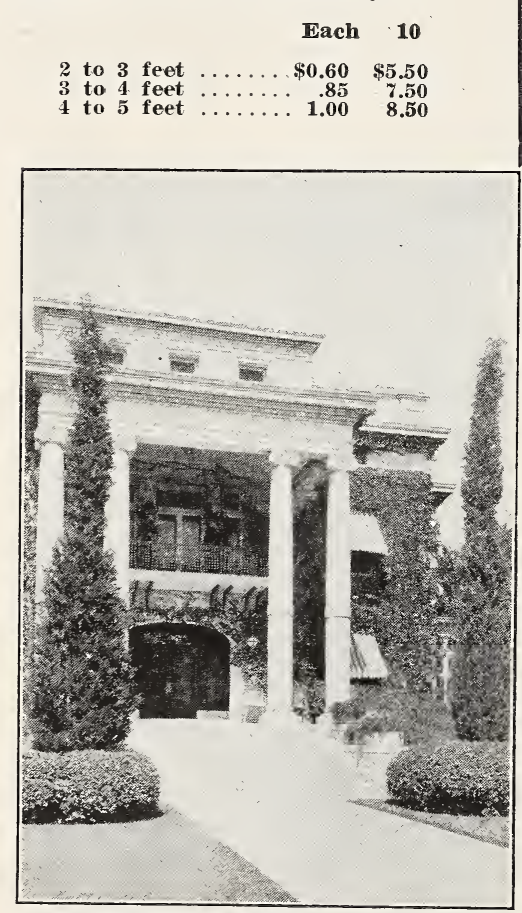

Pittosporum as We Use it for Formal Planting.
RAPHIOLEPIS INIICA (Indian Hawthorn). Low-branched shrub with thick row-branched shrub with thick, roundish, evergreen leaves and pinkish white flowers, will not succeed on poor, thin lands.

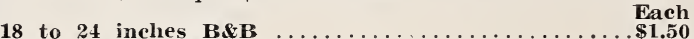

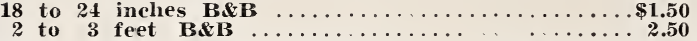

SESBANIA PUNICA or DAUBENTONIA. Rapid growing deciduous shrub. Acacia-like foliage. Flowers brilliant orange-scarlet in drooping racemes. Useful for backgrounds and among large evergreens.

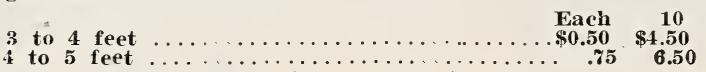

\section{SPIREA}

Dainty, graceful, flowering shrub, very desirable for informal hedges, mass or specimen planting, and for bordering the taller growing shrubs.

Van Houttei. The well known Bridal Wreath. Widely grown favorite with dense foliage. White blooms in early Spring. Leaves persistent in Fall, a desirable feature.

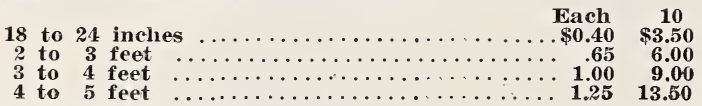

Anthony Waterer. Bright crimson, flat bloom heads. Handsome foliage. Dwarf and dense growth.

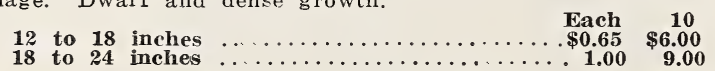

TEA PLANT (Thea Sinensis). The Tea of commerce. Broad-ieaf evergreen. Beautiful glossy dark green foliage. Good for rnass planting or specimens.

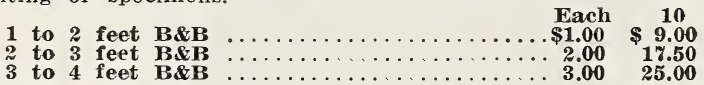

To every home owner is given the same opportunity to have a most pleasing landscape affect. Proper grouping provides for a succession of bloom from early Spring until late Fall with ample evergreen for Winter with striking berries and fruit.

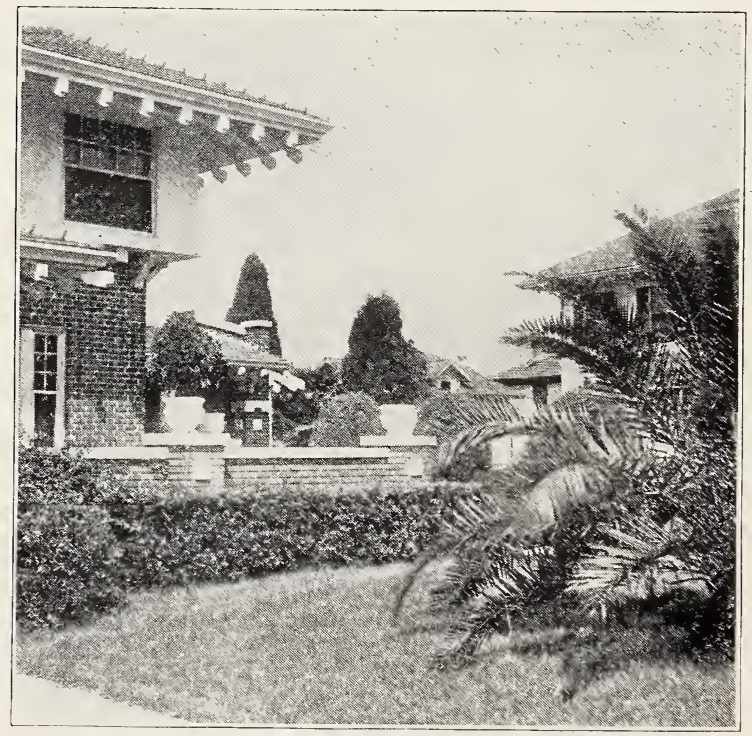

Right, Phoenix Canariensis Palm; Hedge Pittosporum.

B $R$ Wherever you find this mark $B \& B$ it stands for Balled and Burlapped, meaning the roots are dug It assures stock living as securely wrapped in burlap. We always recommend such stock balled. 
THUNBERGIA ERECTA (Bush Morning Glory or King's Mantle). Handsome shrub for the lower South. Too tender farther north without protection from frost. Blooms continuously throughout the year. Flowers dark blue, two inches across.

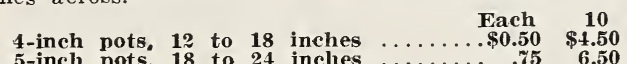

VIBURNUM TINUS LAURUSTINUS. A handsome, broadleaved flowering shrub of rapid growth. Flowers creamy white. Very fragrant. The buds are bright red.

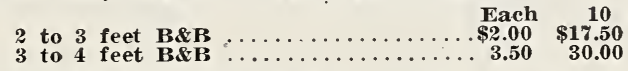

VIBURNUM ODORATISSIMUM (Seedling). Another rare form of great beauty; rather spreading habit, with glossy dark green foliage and very fragrant, pure white flowers in large panicles appearing in April or May. Attains a height of 6 feet.

$$
18 \text { to } 24 \text { inches (Pots) } \ldots \ldots \ldots \ldots \ldots \$ 1.25 \quad \underset{\$ 10.00}{\text { Each }}
$$

\section{WEIGELA - Diervilla}

Medium to large shrub, spreading habit; great masses of bright color in late spring.

Grandiflora. Large blossoms, brown tinge when in bud, crimson when open.

Gigantiflorum. Very large blossoms.

Hendersoni. Flowers light crimson.

Rosea. Rosy pink flowers in profusion; very early bloomer; showy.

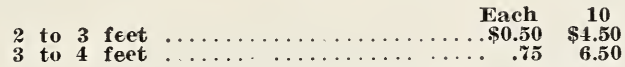

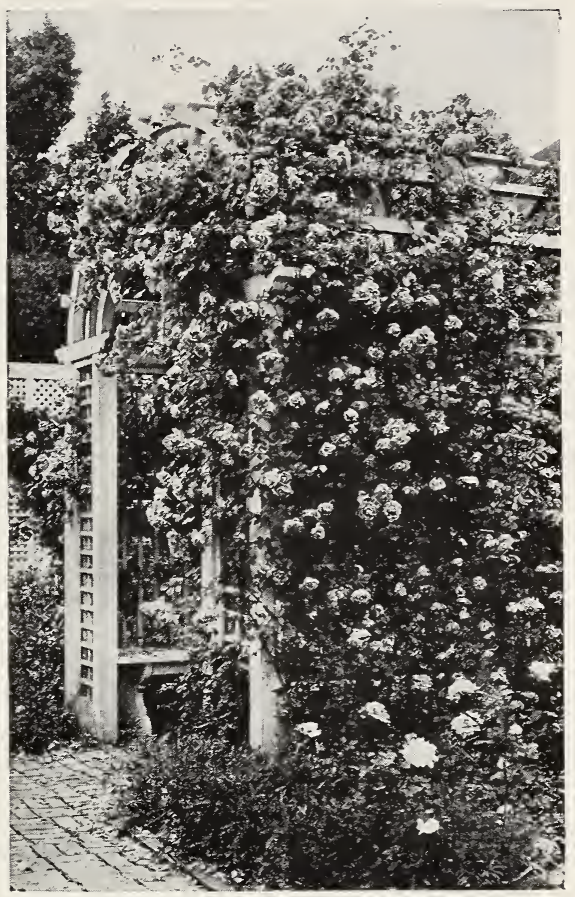

Results With Strong Growing Climbing Roses.

Messrs. C. M. Griffing \& Co.

St. Augustine, Fla.

Jacksonvilie. Friffing

The shipment of plants, etc., (my order of the 16th inst.) arrived this morning, and you will pardon my expression of grateful appreciation for the superb selection of plants you sent me, and for the absolutely perfect manner of packing and shipping, etc. They were quite as fresh and nice as when they left the nursery, I am sure.

I have never, in my twenty-five years or more. of dealing with you received a finer lot of plants, or in better shape, and I thank vou very much indeed. They are now all carefully set out in the grounds of $\mathrm{my}$ new home here, and I feel that they will improve the attractiveness of my property, which is very desirably located, and in which we take a great pride.

You were most kind to include the additional plants without charge, and I am under obligation to you.

When your new catalogs are out I shall take pleasure in distributing three or four dozen among my friends here whom I think will be interested, if you wish to send them.

With best wishes for your continued success, I a m Yours very truly

S. M. MOORE.

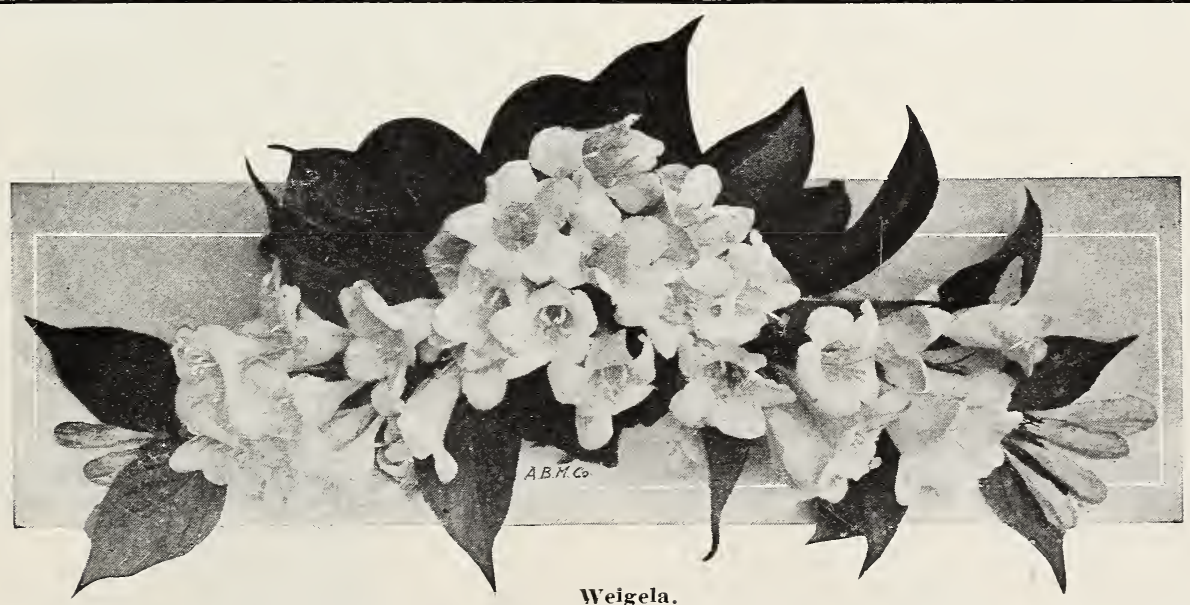
$\mathrm{B} \& \mathrm{~B} \begin{aligned} & \text { Wherever you find this mark } \mathrm{B} \& \mathrm{~B} \text { it stands for Balled and Burlapped, meaning the roots are dug } \\ & \text { with firm ball of earth and securely wrapped in burlap. We always recommend such stock balled. } \\ & \text { It assures stock living as well as immediate effect. Foliage retained. Quicker and better results. }\end{aligned}$ 


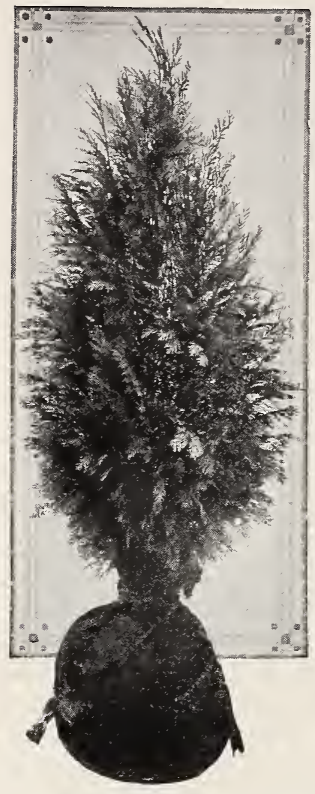

Chamaecyparis Lawsoniana-Lawson's Cypress.

\section{Coniferous Evergreens \\ ONE OF THE FINEST AND LARGEST COIAECTIONS IN THE SOUTH}

\section{Arbor-Vitaes - Biota - Asiatic Type}

A distinctive group of evergreens. Properly placed, they add an atmospher of elegance to a planting not attainable with other plants. Beautiful beyond com parison, the many plants under this head are so widely varying that they are found for every purpose. For low, sharp-cut, formal hedges; perfectly symmetrica specimen plants, either compact or loosely branched; high, dense screen planting foundation plantings; shade and ornamental trees; and for general effectiveness in masses of shrubbery-the Conifers demand attention above all classes of plants. Hardy and thriving when established, we have found that Conifers to be successfully transplanted, must be handled B\&B. While all permit shaping, the lower limbs should always be left close to the ground for beauty.

All Arbor-Vita $\in$ s will be Balled and Burlapped unless stated otherwise. We consider it best to ball and burlap conifers as compact fibrous roots are not disturbed when dug with ball of dirt. Our balling methods suring your securing plants in perfect condition. It also insures immediate effect and lasting beat

CAUTION. Never lift B\&B stock by the top branches. Put both hands around ball so as not to locsen the ball any.

AUREA CONSPICUA. The most beautiful and artistic of all pyramidal ArborVitaes. Always maintains a perfectly symmetrical pyramidal form, branching close to the ground and tapering gradually to the tip. Probably the most golden of all Arbor-Vitaes. Fine in groups or as single specimens.

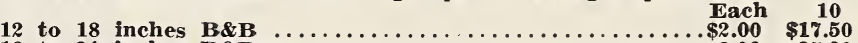

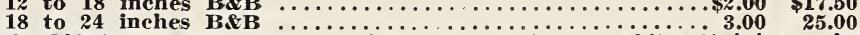

AUREA NANA (Dwarf Golden). Fine plant of dwarf habit, attaining a height of 6 to 8 feet. Compact and bushy; rich, golden-tipped foliage. Always beautiful from the little plant until maturity. Slow growth permits many uses.

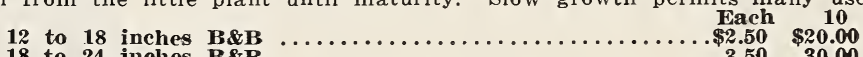

BONITA to beautiful, broad, cone-shaped Arbor-vitae of unequalled richness, in color and perfection of form. The most attractive and useful of all varieties. in color and perfection of form. The most attractive and useful of all varieties. Makes uniformly perfect growth, every twig being placed naturally in correct
position. Slow growth makes it desirable where other shrubs would over-grow. An ideal Arbor-Vitath makes it desirable where

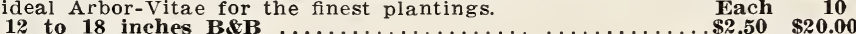

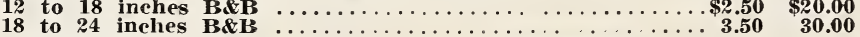

CHINENSIS (Chinese Arbor-Vitae). Pale golden green; upright thrifty grower; fine for screens, hedges or windbreaks. Wil grow anywhere, easy to transplant. Can be kept into compact tree by frequent careful pruning pact tree by frequent, careful pruning. Our stock has bee pruned and is handsome and
Seedlings:
18 to 24 in., Bare Roots $\$ 0.50$
2 to 3 ft., Bare Roots $\$ 0.50 \quad \$ 4.50$
10
6.00
100
3 to 4 ft., Bare Roots .95
4 to 5 ft., $B \& B$
5 to

CHINENSIS COMPACTA. A type of the Orientalis with compact, broad, cone-shaped growth. For planting where a lower type is desired than the Pyramidal. Not so compact as the dwarf varieties. Requires some pruning, but for inexpensive planting can be used as substitute for the varieties of ing can be used

Selected Seedlings:

18 Each 10

24 to 30 in., Bare Roots $\ldots \ldots . \$ 1.00$ \$ 9.00

30 to 36 in., Bare Roots $\cdots \cdots \cdot 1.25 \quad 11.50$

3 to 4 ft., Bare Roots $\ldots \ldots \ldots$ 2.25 20.00

CHINENSIS PYRAMIDALIS. Upright growth. Tapers from broad base to tip. Useful in landscape planting for high points in groups of broad-leaf shrubs. In foundation planting, it is valued for corners and between windows.

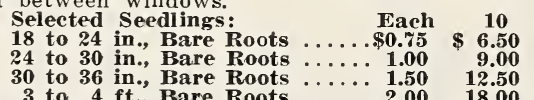
Above two varieties can be moved bare-rooted but are better when B\&B. Double the price for B\&B stock. When used for hedges or windbreaks, just order Bare Roots.

COMPACTA (Dwarf Green). Similar to Dwarf Gold $\in$ except having bright green foliage. Very attractive. 18 inches $\mathbf{B} \& \mathbf{B}$

12 to 18 inches $\mathbf{B \& B} \ldots \ldots \ldots \ldots \ldots \ldots \ldots \ldots 2.50$
18 to 24 inches $B \& B$

ELEGANTISSIMA. Üpright cone form, branchlets flattened. Bright light green with golden yellow tips. Beautiful and striking formal Arbor-Vitae: suitable for single or group pormal

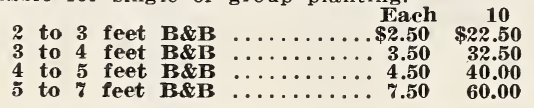

Wherever you find this mark B\&B it stands for Balled and Burlapped, meaning the roots are dug with firm ball of earth and securely wrapped in burlap. IV always recommend such stock balled. It assures stock living as well as immediate effect. Foliage retained. Quicker and better results.

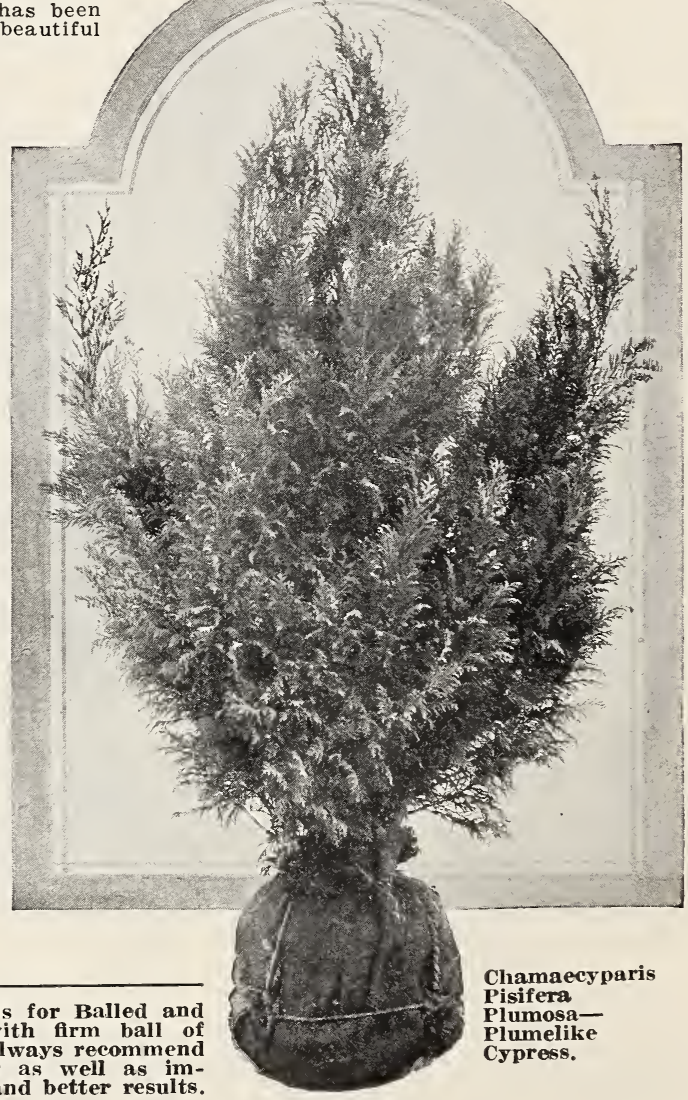




\section{ARBOR-VITAE-Continued.}

ROSEDALE. Bluish gray follage; making a very striking plant; unlike any other Arbor-Vitae. Perobservers. Widely used for tubs and urns.

12 to 18 inches $\mathbf{B \& B} \ldots \ldots \ldots \ldots \ldots \ldots \ldots 2.50$

18 to 24 inches $\mathbf{B \& B} \ldots \ldots \ldots \ldots \ldots \ldots \ldots \ldots$

PYRAMIDALIS (Green Spire-Shaped Arbor-Vitae). Of erect, symmetrical growth, attaining considerable height, forming a narrow shaft, often 20 feet whil only 2 to 4 feet through. A most pleasing and contrasting effect when planted among varieties of more spreading shapes.

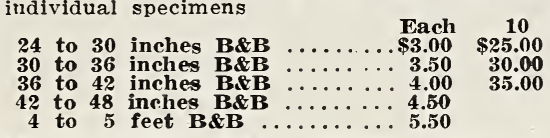

TEXANUM GLAUCA PYRAMIDALIS. Bluish green foliage, pyramidal in character of growth; similar
2 to 3 feet $B \& B$
Each 10
3 to 4 feet $B \& B$
$\begin{array}{rr}\mathbf{3} .50 & \$ 22.50 \\ & \mathbf{3 2 . 5 0}\end{array}$

\section{Junipers and Cedars}

The upright, medium and low-growing or creeping Junipers are in a class by themselves as evergreens of high quality, brilliant coloring and a wide range in orm and manner of growth.

We offer a great variety to choose from. They fill ositions other plants out positions other plants outgrow or lack quality for. of great value in planting the home or larger grounds. VIRGINIANA (Red Cedar). Sturdy, thrifty, strong grower. A native, well adapted for shade and orgrower, easily trained into formal shapes.

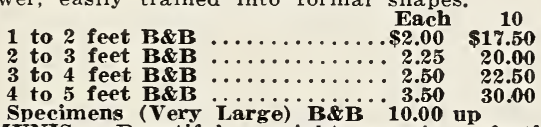

Specimens (Very Large) B\&B 10.00 up
CoxMUNIS. Beautiful, upright growing, feathery foliage, of varying arrangement, silvery blue in color. Is desirable specimen and splendid for color groups and foundation planting. Each $\mathbf{1 0}$

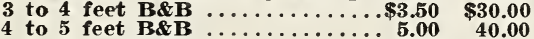

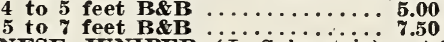

JAPANESE JUNIPER ( $J$. Sylvestris). Adapted to a great range of climate, temperature and soll. A beautiful tree; brint green foliage; pyramidal, compact growth. This type of Arbor-Vitae grows ex-

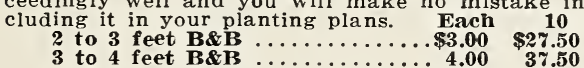

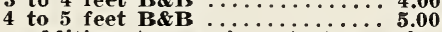

In addition to regular stock we have these in Specimens, which are trained specially into pyramidal form. Something new and extremely valuable for landscape and home beautification in southern states, particularly Florida.

3 to 4 feet B\&B ............ Each

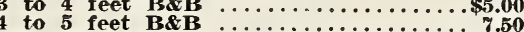

CHINESE JUNIPER. Foliage similar to Japanese

Juniper but of more compact and dwarf growth. Branches beautifully variegated golden yellow. Does not burn in Summer. Very desirable.
3 to 4 feet $B \& B$
$\begin{array}{lc}\text { Each } & 10 \\ \$ 3.00 & \$ 25.00\end{array}$
4 to 5 feet $B \& B \ldots \ldots \ldots \ldots \ldots \ldots .4 .00 \quad \$ 35.00$

CEDAR DEODARA (Cèrü Deodära). called Himalayan Cedar. A stately tree of grea beauty; native to the Himalayan Mountains. Foliage is an attractive bluish green, the young follage appearance of tufts of blue feathers. One of the most beautiful ornamental Cedars for the South.

$$
\begin{aligned}
& 1 \text { to } 2 \text { feet } \mathbf{B} \& B \quad \ldots \ldots \ldots \ldots \ldots \ldots \ldots \ldots \ldots \\
& 2 \text { to } 3 \text { feet } B \& B \ldots \ldots \ldots \ldots \ldots \ldots, \mathbf{3 . 0 0} \quad \mathbf{2 7 . 5 0} \\
& 3 \text { to } 4 \text { feet } B \& B \quad \ldots \ldots \ldots \ldots \ldots \ldots, 4.00 \quad 37.50
\end{aligned}
$$

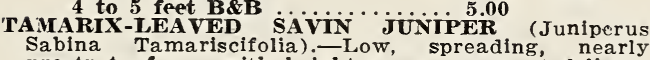
prostrate form, with bright green, compact foliage; thrives best in moist, fertile soil, and attains a more.

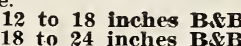
Each $\$ 2.00$
IRISH JUNIPER (Juniperus Communis Hibernica). Densely compact, of a slender columnar form; light gray-green foliage; prefers partial shade, and light, well drained but moist soil. Ultimate height 12 to

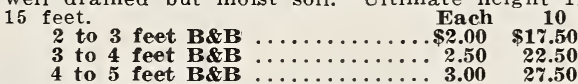

\section{Cupressus - Cypress}

ITALIAN CXPRESS (Cupressus Sempervirens). This well known popular conifer is most desirable where a formal effect is desired. Is of compact and shaftlike habit, attaining a height of 50 feet or more. In sizes 3 feet up to $\%$ feet at $\$ 1.50$ per foot.

ITALIAN CYPRESS, Horizontal Type. Similar to Italian Cypress but more open and spreading. These iferous groups.

In sizes 3 fcet up to 5 fect at $\$ 1.50$ per foot.

\section{Yew - Taxus}

JAPANESE YEW (Cephalotaxus Pedunculata). Small tree of compact, bushy form, glossy dark green, ong, narrow leaves. \begin{tabular}{l}
12 to 18 inches B\&B or Pots $\ldots . \$ 1.25$ \\
18 to 24 inches B\&B or Pots $\ldots .00$ \\
\hline 1.75
\end{tabular} JAPANESE PIUM YEW (Cephalotaxus Drupacea). This is a rare and dwarf-growing Japanese Yew, which is almost trailing in its habit. An excellent low-spreading effect is desired. A most effective plant.

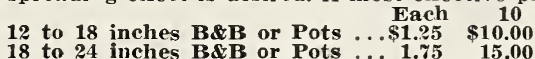
$\begin{array}{ll}18 \text { to } 24 \text { inches } B \& B \text { or Pots } \ldots \ldots 1.75 & 15.00 \\ 24 \text { to } 30 \text { inches } B \& B \text { or Pots } \ldots .2 .25 & 20.00\end{array}$

\section{Retinispora - Chamaecyparis}

PIUMOSA (Plumed Cypress). A pleasing variety of rapid growth with somewhat pendulous branches: bright green, plumelike foliage; ultimate height 20 situatior:s. Succeds in tubs and most soils

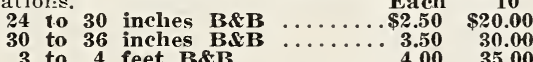

3 to 4 feet B\&B $\ldots \ldots \ldots \ldots \ldots \ldots 4.00 \quad 35.00$

PLUMOSA AUREA (Golden Plumed Cypress). One of the best, hardiest and most desirable Retinisporas. A vigorous grover and retains its golden color constant!y

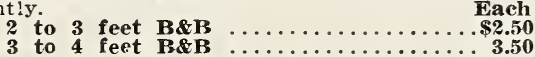

PISIFERA. A hardy, rapid-growing tree with bright green, pendulous foliage, broadly pyramidal in form. ultinate height 18 to 20 feet; most soils and situations

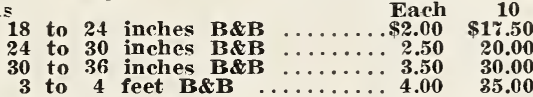

PISIFERA AUREA. In foliage and habit of growth similar to R. Pisifera except that the new growth is of a rich golden hue. A very showy variety.

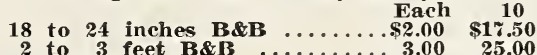

SQUARROSA VEITCHI (Veitch's Silver Cypress). A broad, pyramidal tree with fine, soft-textured foli age of a light silvery blue-green, arranged in bilsirable. Adapted to most soils and situations, and attains a height of 15 to 18 feet. Each

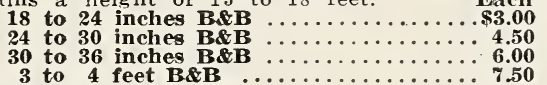

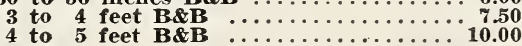

LAWSONIANA. Graceful plant of medium height, erect growth, broad at base, tapering to point at tips; branches reflex with glaucous tips, under surPrefers dry, will drained situations. Ultimate height 10 to 15 feet.

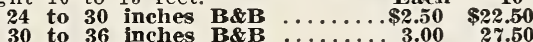

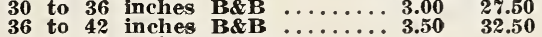

$\begin{array}{rrrr}36 & \text { to } & 42 & \text { inches } B \& B \\ 42 & \text { to } & 48 & \text { inches } B \& B \\ 4 & \text { to } & 5 & \text { feet } B \& B\end{array}$

OBTUSA. A slender, rapid growing plant, rather open in habit, with cupped foliage of a dark green color; usually of medium height. Prefers a rather fertile soil.

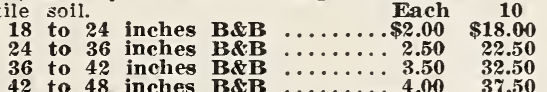
B 8 Wherever you find this mark B\&B it stands for Balled and Burlapped, meaning the roots are dug It assures stock living as well as immediate effect. Foliage retained. Quicker and better results, 


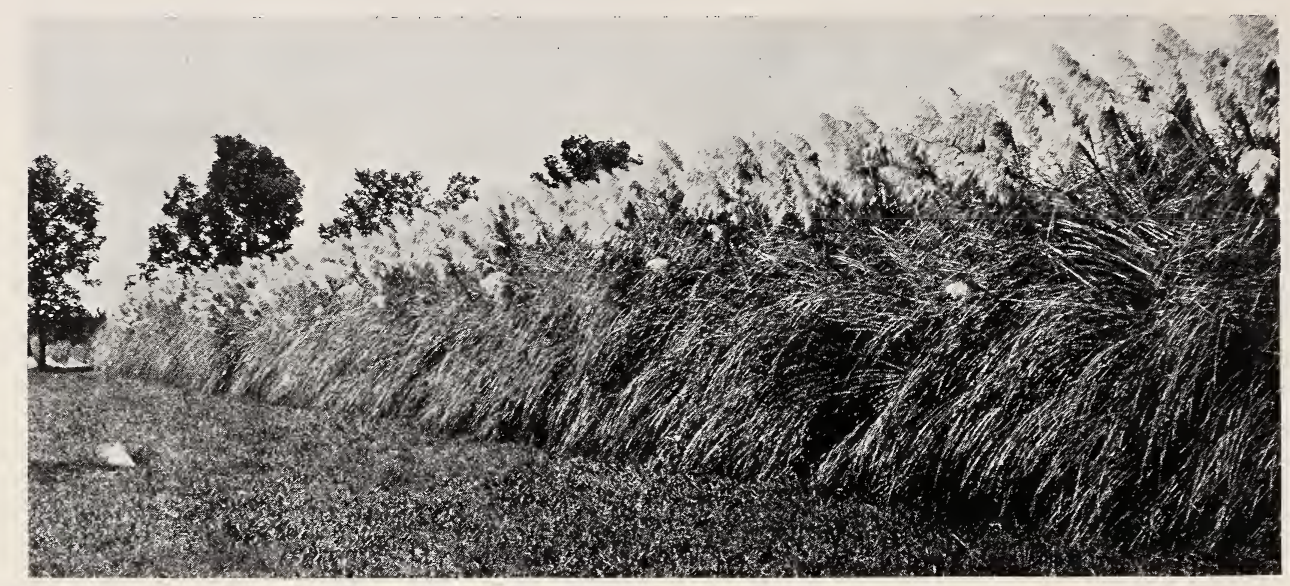

A Pampas Grass Border is Beautiful in Landscape Work.

\section{BAMBOOS AND GRASSES AND MISCELLANEOUS}

There are many beautiful ornamentals which are not classed as shrubs or trees, yet have infinite value in landscape and ornamental planting. Particularly in the South do we have many beautiful plants of miscellaneous nature which should be generously planted for quick effect, for economy and in many instances for the atmosphere of the tropies which they produce in plantings.

\section{BAMBOOS - Bambusa}

Of all ornamental plants, none deserve more attention than the Bamboos. Dense plumelike foliage, eniirely evergreen, makes them ideal specimens on lawns and in parks where they are generously used. Certain varieties make beautiful screens for hiding garages and outbuildings and obstructing unsightly views. Argentca (Japanese). Attains 30 feet. Beautiful, very serviceable. Dark green, rounded form. serviceable. Dark green, rounded form.
Argentea Striata. Similar except foliage striped with
white. Height 20 feet.

Falcata. Fine leaf, small-growing species. 8 to $12 \mathrm{ft}$. Verticillata. Canes striped yellow, rank grower, attains 20 to 30 feet. One of the best for specimen clumps and windbreaks. 5 stalks $\$ 0.50 \quad \$ 4.50$

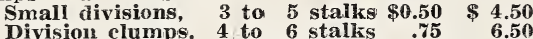
Division clumps, 6 to 12 stalks $1.00 \quad 9.00$ Division clumps, 12 to 15 stalks $1.50 \quad 13.50$

\section{GRASSES}

FCLALIA GRASS (Miscanthus) This beautiful group of lawn grasses is widely known and grows in all riegated foliage. Makg distinctive specimens. Grows 5 to 6 feet. Very graceful.

Univittata. Bushy clumps, dark green blades.

Univittata. Bushy clumps, dark green blades. Variegata. Similar, white stripes lengthwise of blades.
Zebrina. Similar to green, with white cross-striping. Small clumps $\ldots \ldots \ldots \ldots \ldots \ldots \ldots \ldots \mathbf{\$ 0 . 5 0} \$ \mathbf{\$ 4 . 5 0}$

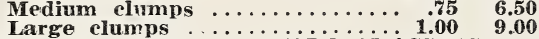

PAMPAS GRASS or FoUNTAiN GRASS (Cortaderia Sellvana). Ornamental grass. Light green foliage, gracefully recurved. Makes large clumps 8 to 12 feet. In Summer sends up tall, silvery plumes which are very distinctive and beautiful. Makes fine specimen plants. In shrubbery groups it is just the right contrast. Border hedges are frequently formed with it. Large clump divisions $\ldots \ldots . \$ 90.60 \$ \mathbf{9 0} \$ \mathbf{8 . 0 0}$ Extra large clump divisions $\ldots . .25 \quad 10.00$

UMBRELLA GRASS (Cyperus Aiternifolius). Long stems surmounted by a whorl of foliage suggestive Excellent as specimen and at its best near pool or Excellent as specimen and at its best 10
water.

\section{ASPIDISTRA LURIDA} Attractive plant with wide-blade foliage of good
size. Dark green color. Excellent for low foundation planting and groups in lower South. ......\$.

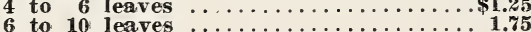

\section{LILIES}

Crinum. Wide blade-leaf, averaging 1 to 3 feet long. Blooms late Summer and early Fall, producing long stalk with several gorgeously colored blossoms.

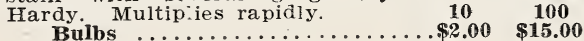

GLADIOLI, The best home varieties.

America. Pale pink. Francis King. Salmon. Chicago. White. Panama. Shell-pink.

TUBERosE, Mexican Everblooming. Superior variety giving abundance of flowers when others are scarce. Long stems bearing many waxy, pure white, exceed-

$\begin{array}{llcc}\text { Prices, Tuberose and Gladioli: } & 10 & 100 \\ \text { Bulbs } & 10 \ldots \ldots \ldots \ldots \ldots \ldots \ldots \ldots \ldots \ldots . \$ 1.25 & \$ 10.00\end{array}$

\section{SANSEVIERIA ZEYLANICA - Bow String Hemp}

Herbaceous plant with stiff, erect, sword-shaped leaves of dark green with silvery markings. Beautiful plant for pot or other container. Tropical effect. ls excellent for indoor and sunroom use. Fach Medium size pot plants $\ldots \ldots \ldots \ldots \ldots \ldots \ldots \ldots \ldots \ldots \ldots \ldots \ldots \ldots \ldots$
Large size $\ldots \ldots \ldots \ldots \ldots \ldots \ldots$

\section{AGAVES}

Americana Variegata (Striped Century Plant). This is the large grotesque plant with twisted leaves, dark green and striped yellow on the edges, so frequently seen in the tropical garden.

Miradorensis (Dwarf Century Plart). A rare form of particular value in patio and similar situations where its small size is well suited. The leaves are short and compact, recurving beautifully, the whole plant and compact, recurving beautifully, the whole plant growing about 2 feet high

Neglecta (Blue Century Plant). Rich blue-green eglecta (Blue Century Plant). Rich blue-green est large sort in our collection, and fairly hardy. A est large sort in our collection, and fairly hardy. A magnificent plant, beautiful in all sizes, and fine for all decorative purposes. Fine plants, with beauti
leaves.

Small \$0.50 Medium
Large 1.00

\section{YUCCA}

Aloifolia (Spanish Dagger or Bayonet). This is the spiny, upright plant typical of tropical landscapes. Good for contrast with other plants. Frequen

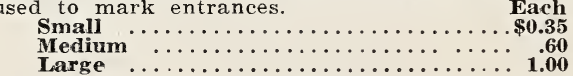

\section{CANNAS}

Good for cheap, quick effect. When used in this way, plant informally as a border for shrubs until more permanent plants attain fu'l growth.

King Humbert. The grandest Canna ever offered; bronze foliage, crowned with immense heads of orchid-like flowers; color velvety orange-scarlet. Indiana. Green foliage; color soft orange, lightened by soft flakes of gold.

Wyoming. Bronze foliage, orange flowers; resembles

Indiana.
Pennsylvania. Soft dark scarlet; green foliage. Bulbs $\ldots \ldots \ldots \ldots \ldots \ldots \ldots \ldots \ldots \$ \mathbf{\$ 2 0 0} \quad \mathbf{\$ 1 5 . 0 0}$ 


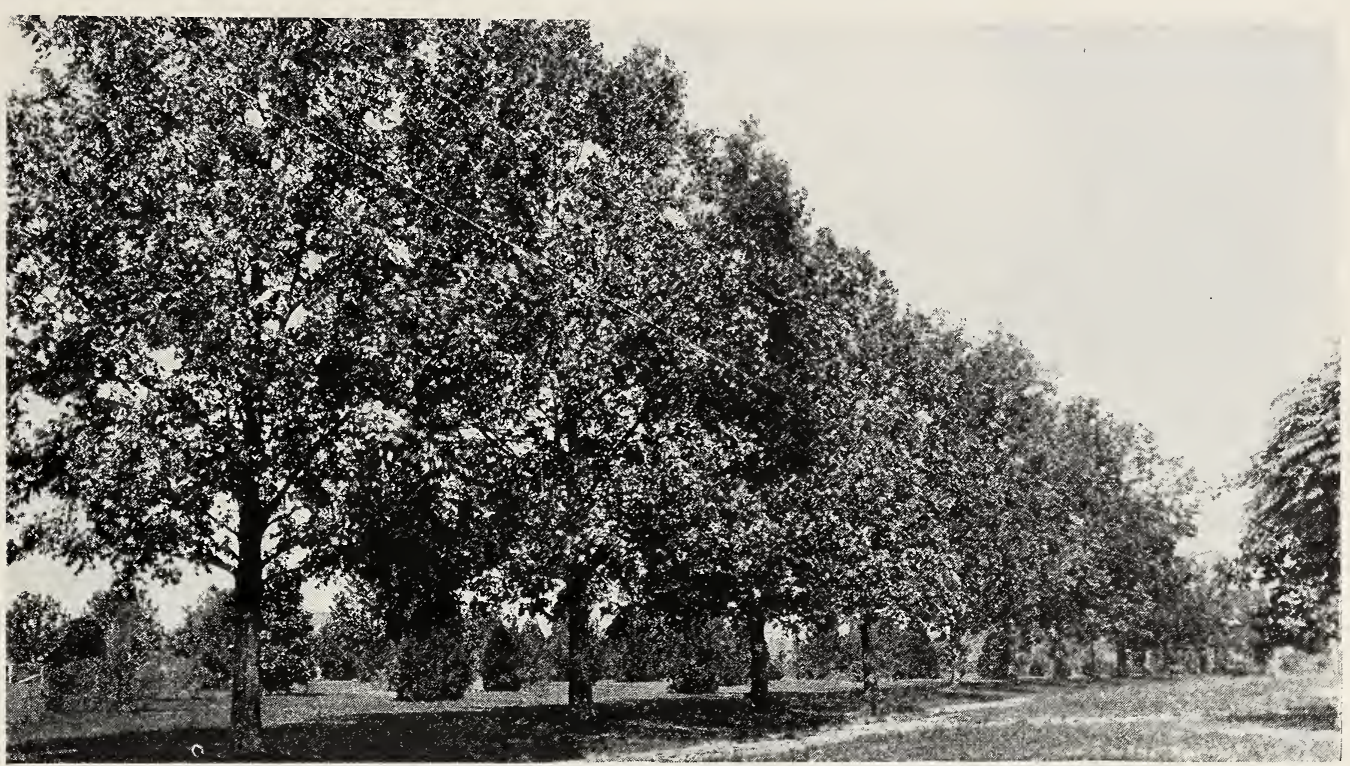

Pecans as the Beautiful and Useful A venue Tree Bordering Our Nursery Grounds.

\section{Shade and Ornamental Trees}

In this group we have listed the best medium and large growing trees suitable for shade and street planting or for ornamental value and adaptability to general landscape work. Not only necessary for beauty and comfort, shade trees are the most advantageous means of increasing the value of southern home property. GRIFTING'S RIO GRANDE ASH (Fraxinus Velutina). A most beautiful shade tree for either street or lawn purposes. Clean growth, no leaf-littered lawn during late Summer ard early Autumn. Trunk very straight, covered with grayish white, smooth bark. Foliage dark green, very glossy. Remains on tree until coldest freezing weather. First to put ou young leaves in Spring. Young trees practically evergreen in coastal sections. Beautiful immediately after planting. Safe for coastal plantings where there are occasional salt water inundations. Plantings alviays receive attention by visitors and have met with the universal approval of our trade. Recommended for extensive planting in Gulf states. A rapid grower.
5 to 6 feet $\ldots \ldots \ldots \ldots \ldots \ldots \ldots \ldots \ldots \$ \ldots 1.25$

6 feet up ........................ up

AUSTRALIAN PINE or CASUARINA. Not a true Pine, having no pitch or resin. Beautiful, rapid-growing trees with odd follage and branching resembling the native Pines. Adapts itself to almost any soil. Will not only endure salt spray but will thrive on the driest and poorest sandy ridge, miles inland. One of the best trees we know of for sub-divisions where soil and cultural conditions are not good and where quick results are important. A splendid street tree, giving quick results; also good as specimens and for group plantings.

Cunninghamiani. 'This variety has stood a temperature of 20 degrees above in Florida in 1918 and is said by Department of Agriculture officials to be immune to a minimum of 10 degrees.

Stricta. Extensively used in California. A prominent nurseryman there writes-"it is our opinion that they will stand a temperature as low as 10 degrees Fahrenheit, although they may stand lower temperatures." Potted plants, 2 to 3 feet $\ldots \ldots \ldots 1.25 \quad \$ 10.00$ $\begin{array}{llll}\text { Potted plants, } 3 \text { to } 4 & \text { feet } \ldots \ldots \ldots & 1.50 & 12.50 \\ \text { Potted plants, } 4 \text { to } 5 \text { feet } \ldots \ldots & 2.00 & 17.50\end{array}$

AUSTRALIAN SILK OAK (Grevillea Robusta). An attractive tree of fernlike foliage. A splendid shade or ornamental trec and very desirable for pot culture. $\approx$ to 3 feet, potted plants $\ldots \ldots . \$ 0.50 \quad \$ 4.00$

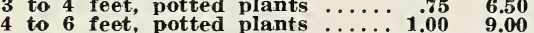
CAMPHOR TREE (Cinnamomurn Camphora) splendid shade tree for the lawn, street or for park planting. Dense, bright green, glossy foliage all the year. A few leaves turning red in Autumn making an exceptionally attractive sight. Clean growing and very symmetrical. No leaves to rake np and the natural compact elliptical form avoids necessity for trimming. Camphors are grown in bush and tree form. Be sure to specify which you want.

$$
\begin{aligned}
& 2 \text { to } 3 \text { feet } \ldots \ldots \ldots \ldots \ldots \$ \$, \begin{array}{c}
\text { Each } \\
\$ 4.50
\end{array} \\
& 3 \text { to } 4 \text { feet } \ldots \ldots \ldots \ldots \ldots \\
& 4 \text { to } 5 \text { feet } \ldots \ldots \ldots \ldots \ldots 1.25 \quad 10.00 \\
& \text { B\&B at double above prices. }
\end{aligned}
$$

\section{Eucalyptus - Australian Gum}

Very fast growing evergreen trees, highly desirable where hardy.

Robusta. Symmetrical branching, well adapted to

Rudis. A hardy variety much grown in Texas. Stands

drought better than most varieties. A beautiful

avenue tree; young growth of deep copper color.

rereticornis. Valued for posts and timber. Strong grower and quite hardy.

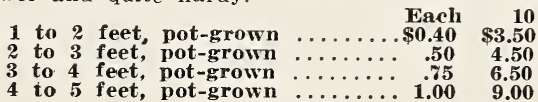

\section{Holly - Ilex}

\begin{tabular}{|c|c|c|c|c|c|}
\hline & & & & Eacl & \\
\hline t & & feet & $\ldots .$. & $\$ 1.00$ & $\$ 9.00$ \\
\hline t & 4 & feet & $\ldots \ldots \ldots \ldots \ldots$ & 1.25 & 11.50 \\
\hline & 6 & feet & $\ldots \ldots \ldots \ldots \ldots \ldots$ & 1.75 & 15.0 \\
\hline$t$ & 10 & feet & $\cdots \cdots$ & $\begin{array}{l}3.00 \\
5.00\end{array}$ & \\
\hline
\end{tabular}

Opaca (American Christmas Holly). Grows to 20 feet tall. Handsome tree and valuable for Christmas decoration. Red berries.

Myrtifolia (Myrtle-leaved Holly). Handsome small tree of Holly family with small oblong bright green leaves, handsome red berries in Fall and Winter.

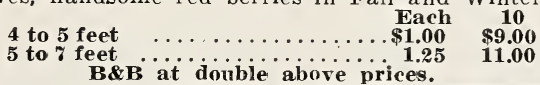

R $R$ Wherever you find this mark B\&B it stands for Balled and Burlanped, meaning the roots are dug $B d \mathrm{D}$ with firm ball of earth and securely wrapped in burlap. We always recommend such stock balled. It assures stock living as well as immediate effect. Foliage retained. Quicker and better resulta. 


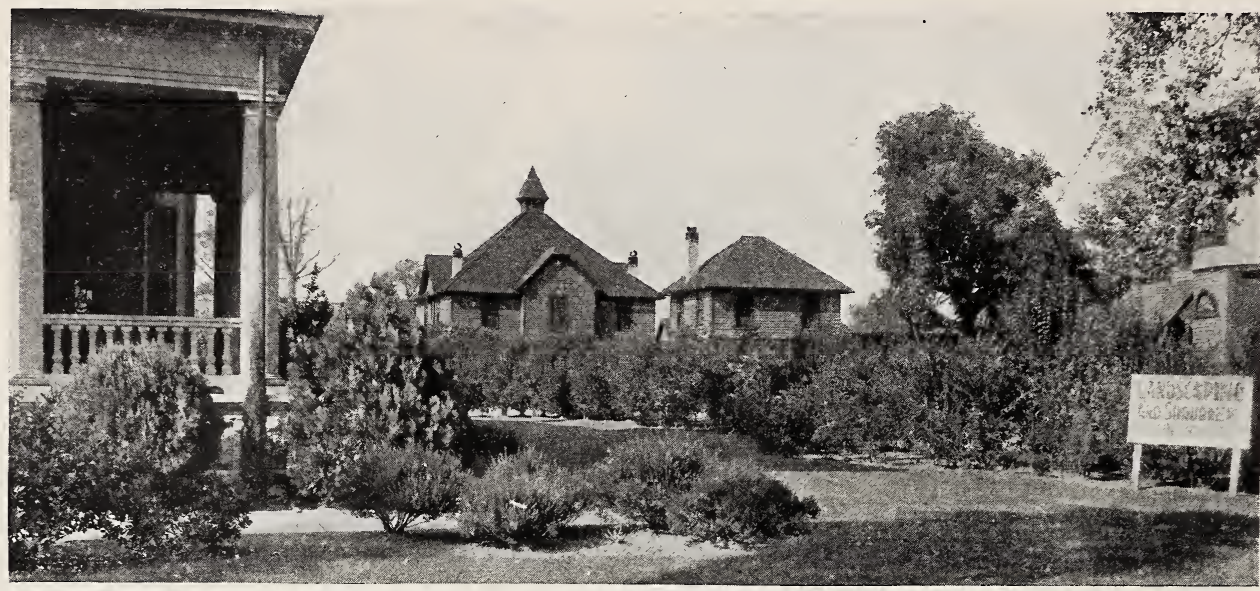

In this Planting, Just Completed, there were used Myrtus Communis, Arbor-Vitae Flegantissima and Compacta, Pittosporum, Several Varieties of Ligustrum, Nandina, Photinia,

\section{Laurel}

Prunus Caroliniana (Southern or Cherry or Wild Peach). Considered among the best broad-leaved evergreen shade trees for Southern planting. Suited to any place where a shade tree is needed. Can be trimmed to any desired size.

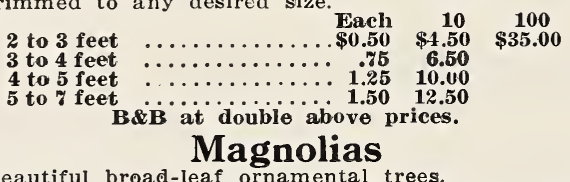

Grandifiora. The broad-leaf evergreen giant of the forest. Immense white blossoms. Well known throughout the South. Beautiful from small tree to maturity.

Glauca (Sweet or White Bay). Handsome native evergreen. Leaves green and lustrous on upper surface, pale or pearly white beneath. Fragrant, creamywhite flowers in late Spring and early Summer.

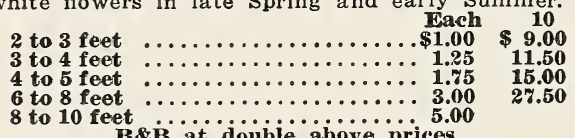

B\& $B$ at double above prices.

\section{Oaks}

Virginiana (Live Oak). One of the finest and most popular Evergreen shade and ornamental trees. Contrary to the general idea, it is a comparatively quick grower, attains immense size, is symmetrical in shape, entirely evergreen, has dark, glossy green foliage and is a very clean tree for lawn and avenue planting.

Laurifolia (Laurel Oak). Tall-growing tree, to 60 feet or more. Comparatively slender branches, in lower South. A most excellent street tree.

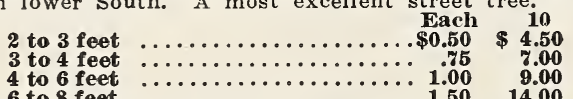

\section{Other Shade and Orname ntal Trees}

\section{All other varieties of our Shade and Ornamental} trees are grouped under the following prices. Sizes of each in stock follow description: Each

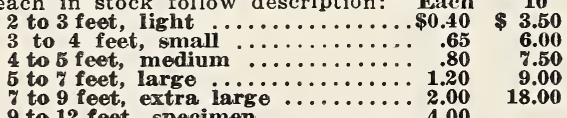

$y$ to 9 feet, extra läre $\ldots \ldots \ldots \ldots \ldots 2.00 \quad 18.00$

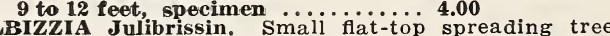
compound leaves; pink flowers in showy large bunches. Fast growing. Sizes: 2 to 3 feet; 3 to 4 feet: 4 to 5 feet.

ASH, Green (Fraxinus Viridis). Rapid growing, symmetrical hardwood tree. All sizes.
CATALPA Speciosa. The big growing kind, valuable for shade and timber. All sizes.

CYPRESS, Bald (Taxodium Distichum). Native cypress. Will grow on dry lands as well as in swamps. Fine for avenue planting. All sizes.

DOGWOOD (Cornus Florida). Handsome small shade tree producing a mass of white flowers in early Spring. 2 to 3 and 3 tol 4 feet only.

ELM, White (Ulmus Americana). Famous in the North and quite well adapted to southern planting. All sizes.

HACKBERRY (C'eltis Sinensis). Handsome small tree. Foliage beautiful for long season, almost evergreen. All sizes to 5 to 7 feet.

MAPLE, Scarlet (Acer Rubrum). A thrifty, stronggrowing Maple adapted to southern planting. All sizes to 4 to 5 feet.

OAK (Quercus Falcata). Strong growing, shapely tree, foliage beautiful in the Fall. All sizes.

OAK, Pin (Quercus Palustris). Tree shapely and symmetrical. Leaves a beautiful tone of green fading in Autumn to brilliant scarlet. All sizes.

PISTACHE (Pistacia Sinensis). Medium size handsome deciduous tree. Leaves finely divided; of striking wine color when young and highly colored in Fall. Sizes: 3 to 4 feet, 4 to 5 feet and 5 to 7 feet, only.

POPIAR, Carolina. A rapid-growing symmetrical, large shade tree. All sizes.

POPLAR, Lombardy. Populus Italica). One of the most striking and picturesque of trees. Valuable for lending distinction to massed plantings. Indispensable in formal lardscape work. All sizes.

POPLAR, Tulip (Liriodendron Tulipifera). A majestic tall growing tree, sometimes attaining a height of 150 feet. A very beautiful tree for park and avenue planting Sizes: 5 to 7 feet, 7 to 9 feet and 9 to 12 feet, only.

REDBUD (Cercis Canadensis). Very ornamental small tree, producing a profusion of delicate reddishpurple flowers early in Spring before foliage appears. AIl sizes.

SYCAMORE (Oriental Plane). A desirable shade tree where immediate effect is wanted. All sizes.

SOPHORA Japonica (Pagoda Tree). A native of China and Japan. Leaves compound with five to 12 leaflets, dark green and glossy. Flowers creamy-white borne in great loose panicles. A handsome tree with green barked twigs. Sizes: 2 to 3 feet; 3 to 4 feet; and 5 to 7 feet, only.

TALLOW, Chinese (Sapium sebiferum). Cleanest of deciduous trees. Compact, dense head of small bright green leaves. A beautiful shade tree and very desirable for streets or avenues, anywhere in the South. Highly desirable for any purpose. Attains 40 feet. In mid-Summer and late Fall, when so many trees have yellow and brown falling leaves, the Tallow is beautifully fresh and green. Highly recommended. All sizes to 5 to 7 feet.

TEXAS UMBRELLA (Melia). Too well known to need description. 2 to 3 feet, 3 to 4 feet, 4 to 5 feet, 7 to 9 feet.

WEEPING WILLOW (Salix Babylonica). Native of Asia. Long, slender, dark green branches extending downward. Medium sizes. B 8 Wherever you find this mark B\&B it stands for Balled and Burlapped, meaning the roots are dug It assures stock living as well as immediate effect. Foliage retamed. Quicker and better results. 


\section{Hedge Plants}

There are many widely different varieties of plants which make beautiful hedges and the height and form of each hedge can be sheared to the owner's taste and the needs of the house.

AMOQR RIVER PRIVET (L. Amurense). Most popular hedge for the South. Very beautiful, practically evergreen, dense in growth, very compact and establishes a very good hedge in one year. Hardy and adapted to general planting. Permits shearing to any height or shape.

CALIFORNIA PRIVET. Thick, green foliage; nearly evergreen. Good for hedge or ornamental shrub.
price of Amoor River and California Privet:

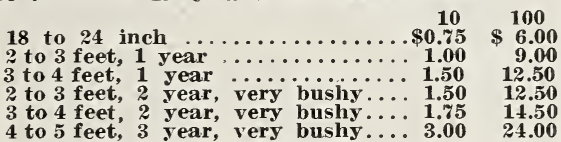

BAMBOO HEDGE. Bamboo can be sheared into round or oval shaped hedges with striking beauty. Entirely evergreen, very dense and compact. Can be kept low or permitted to grow 6 feet or over. Untrimmed it makes a hedge of graceful feathery beauty seldom equaled by any other plant. Tops cut back on Hedge Plants.

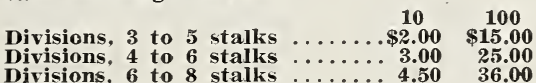

CAMPHOR HEDGE (Cinnamomum Camphora). Camphor as a hedge needs no introduction to these who have seen this beautiful plant in hedres. The same color effects and perennial beauty is had in the hedge, enhanced by its straight lines in the row. Will reach ten feet or more if never trimmed. Requires little attention.

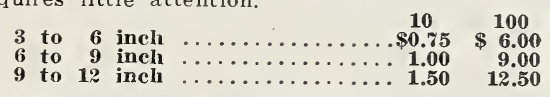

OTHER DESIRABLE HEDGE OR BORDER PLANTS Chinese Arbor-Vitae, All Ligustrums; Laurel; Oleander; Pampas Grass; Pittosporum; Althea: Crape Myrtle; Flowering Pomegranate and Spirea. (See

CHERRY LAUREL.

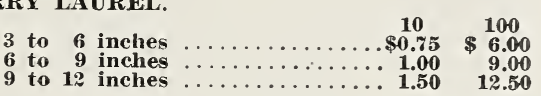

\section{Vines}

Beautiful. artistic vines quickly make beauty spots of each nook and corner, hide all unsightly views, and surround the home with colorful, fragrant blossoms.

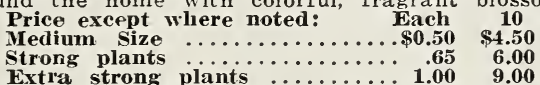

Strong plants $\ldots \ldots \ldots \ldots \ldots \ldots \ldots \ldots$
Extra

ALLAMANDA Hendersoni (Golden Trumpet). One of the most gorgeous tropical plants grown in Florida; may be trained either as a vine or shrub, and will may be trained either as a vine or shrub, and will Srow well up into the southern edge of our Gulf remedied by a few weeks of spring weather. Glossy green, broad leaves; flowers constantly produced, four to five inches across, pure golden yellow. Makes a charming combination with strong blue tones.

A. Williamsi (Canary Flower). This is similar to preceding species except in size of flower, which is only about three inches across, and sometimes a $\$ 3.00$ per 10 .

ANTIGONON Leptopus. "Rosa de Montana," "Coral Vine," "Queen's Wreath," and many other names Vine," "Queen's Wreath," and many other names rapid-growing climber from Mexico. Attains great rapid-growing climber from Mexico. Attains great height, producing immense mass
leaves light green, heart-shaped.

\section{Honeysuckle - Lonicera}

Chinese. A showy variety with purplish evergreen foliage, changing to greener shades at maturity. White flowers.

Hall's Japan. Glossy, evergreen follage. Flowers white, changing to yellow.

Golden Netted. Leaves netted with yellow. Ever-

Bougainvillea - Japan Paper Flower

Crimson Lake. Best of the new ones; a rich glowing red, later overcast with purple shades. Very rank grower. 4-inch pots, \$1.50 each.

Sanderiana. Vigorous, woody vine. Magenta colored trained as shrubs.

\section{Clematis}

Paniculata. Flowers white, star-shaped: produced during Summer and Fall. In addition to its flowers. foliage is very handsome.

\section{Ivy}

English Iry (Hedera Helix). Shiny evergreen leaves Extensively used for covering trunks of palms, trees, walls or pergolas.

Boston or Japan Ivy (Ampelopsis Veitchi). Glossy green leaves, excellent for covering stone, concrete, wood or brick walls.

Virginia Creeper, Improved (Ampelopsis Engelmanni). For the same uses, but has finer cut leaves than the
Boston Ivy, shorter joints and more rapid growth.

\section{Jasmines}

Carolina Yellow Jasmine (Gelsemium Sempervirens). A very graceful, slender, rapid-growing native vine with dark green leaves; yellow flowers produced in abundance in early Spring. Most fragrant.

Star Jasmine (Rhynchospermum Jasminoides). Strong growing, twining vines, glossy leaves; covered in Spring with very fragrant starry white flowers in clusters. Large size only, \$1.00 each.

Jasminum Pubescens. An evergreen vine or scrambling shrub, with beautiful green foliage and showy, white. Shrub, with beautiful green foliage and showy, white.
star-shaped flowers. It may also be grown in shrub form. Quite hardy and a satisfactory vine.

J. Sambac, Grand Duke. A very double-flowered Jasmine. The blooms are frequently $21 / 2$ inches wide and intensely fragrant. Foliage is dark green alld shining.

J. Sambac, Maid of Orleans. Semi-double flowers, $11 / 4$ to two inches wide, very fragrant; constantly in flower. Fin

Star Jasmine Variegated (Rhynchospermum Jasminoides Variegata). Variegated variety of the pre-

\section{Climbing Rubber - Ficus Repens}

The most perfect creeper. Has small, round or ova glossy leaves, short stem. A very tenacious and beautiful climber for covering any kind of masonry.

\section{Wistaria}

The ever popular haray vine for pergolas and porches. Long, drooping clusters of fragrant bloom.

\section{Bignonia - Trumpet Flower}

Radicans Tecoma (Hardy Orange Trumpet). Brilliant orange-red flowers produced throughout the Summer. Dark green leaves A rank climber.

Speciosa (Blue or Purple Trumpet). Evergreen hardy vine. Flowers in great clusters.

Cenusta (Flameflower). A grand, tropical trumpet creeper, growing on houses, high trellises or trees

up to 70 feet or more and producing countless tubu-
lar flowers of a bright orange-red.

\section{Kudzu Vine}

Remarkably vigorous vine frequently producing stems 40 to 60 feet long in a single season-a veritable "Jack-and-the-Beanstalk." Adapted for arbors, verandas, and where quick results are wanted. We recin pecan and citrus groves. Rooted layers, $\$ 1$ per 10 ; in pecan and citrus groves.

\section{Euonymus}

Radicans Acutus. A splendid new introduction with small fcliage and of vigorous growth when established. Much better than the old E. Radicans type. It does well in a variety of soils and clings to any support unaided or will make a good ground cover
if not in dense shade. This is particularly useful for covering palm trunks. 


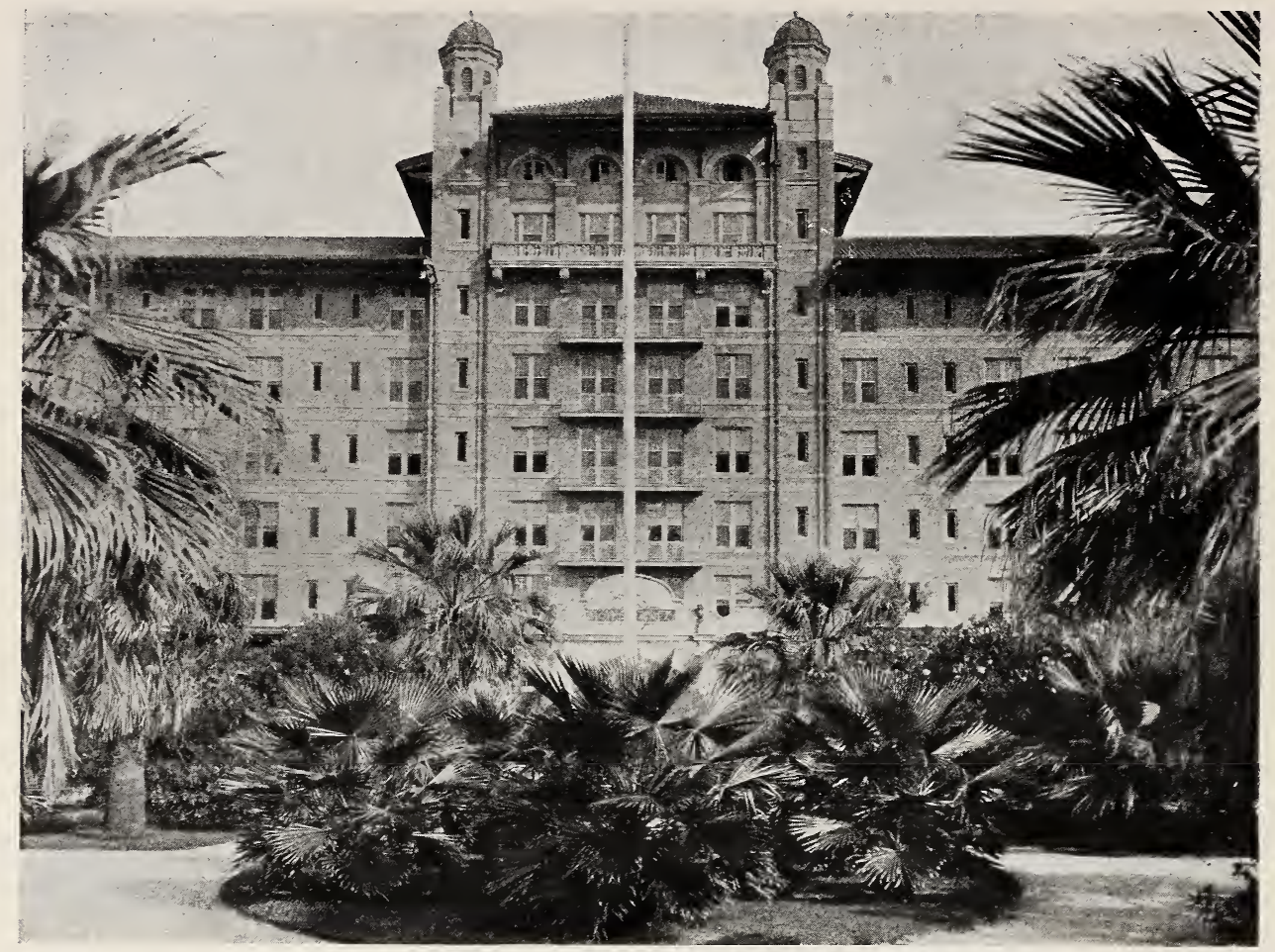

Palms and Oleanders at Hotel Galvez, Right on the Gulf of Mexico.

\section{Palms for Outdoor Planting BALLED AND}

The hardy Palms we list are safe for outside planting from the Coast back about 150 miles and should be extensively planted in the home grounds, parks and streets, and there is nothing that gives a more inviting, tropical effect to our northern visitors than to come where they may be among the waving Palms and enjoy the mild Winters of the southern climate.

CHAMAEROPS EXCELSA (Windmill Palm). Very hardy fan-leaf variety of dwarf habit. Trunk slender, erect, covered with brown flament, making it both attractive and unique. It is well adapted to the northern portion of the Palm
head of rich green leaves.

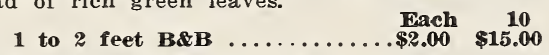

COCos A USTRALIS (Pindo Palm). The hardy Cocos. Exceptionally graceful, long, recurved leaves, pinnate, of impressive, silvery green color. Fruit edible: trunk erect. Beautiful specimens. Very hardy. more so than Phoenix or Washingtonia types.

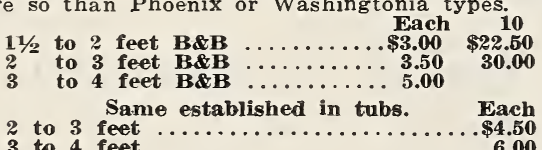

2 to 3 feet $\ldots \ldots \ldots \ldots \ldots \ldots \ldots \ldots \ldots \ldots . \$ \ldots 4.50$

PHOENIX CANARIENSIS (Canary Island Date Palm). Large, graceful, recurved leaves, growth remarkably rapid, general appearance very dark green, beautiful stately trunks; admired by everyone.

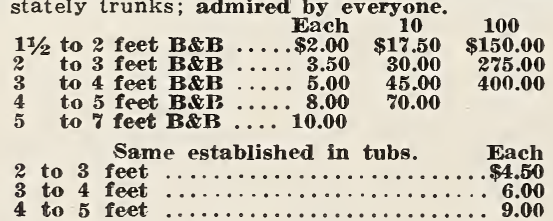

PHOENIX RECLINATA. Smaller and more slender growth than Canariensis. Suckers freely from base, developing into beautiful clumps; very desirable.

3 to 4 feet B\&B $\ldots \ldots \ldots \ldots \ldots . \$ 6.00 \quad \$ 50.00$ 4 to 5 feet B\&B $\ldots \ldots \ldots \ldots \ldots \ldots, 8.00 \quad \$ \quad \mathbf{8 0 . 0 0}$ 5 to 7 feet B\&B $\ldots \ldots \ldots \ldots \ldots \ldots, 12.00 \quad 100.00$ Specimens B\&B ........... 16.00
WASHINGTONIA ROBUSTA. Leaves large. deep green, not deeply serrated, short and somewhat reyellow; tallest growing.

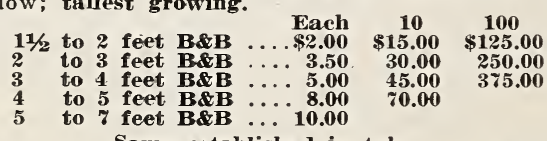

Same established in tubs.

2 to 3 feet $\ldots \ldots \ldots \ldots \ldots \ldots \ldots \ldots \ldots \ldots \ldots \ldots \ldots$

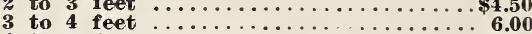

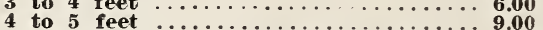

SABAL AMERICANA (Cabbage Palmetto). Broadleaf variety, native of Southern Coast sections. Perfectly hardy, standing temperatures nearly zero Large specimens known as far north as Corsicana. Texas, and the Carolinas.

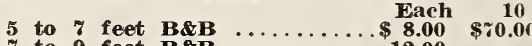

$$
\begin{aligned}
& \text { Specimens B\&B } \ldots \ldots \ldots \ldots \ldots \ldots .16 .00
\end{aligned}
$$

CYCAS REVOLUTA (Sago Palm). A Palmlike Cycad. reaching a height of 3 to 4 feet, with a handsome crown of deep green leaves curved outward from the center; very hardy; grows well out-of-doors in North Florida and along the Gulf Coast. Young plants have but a single stem. Gulf Coast. Young plants have but a single stem; old ones are often
branched. We have a particularly fine lot of these.

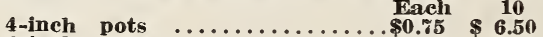

$$
\begin{aligned}
& \text { 6-inch pots } \ldots \ldots \ldots \ldots \ldots \ldots \ldots \ldots \ldots 1.50 \quad 12.50
\end{aligned}
$$

ZAMIA INTEGRIFOLIA (Coontie). This beautifu Cycad is a native Florida plant. It is low-growing. producing tufts of dark green, fernlike foliage. A very satisfactory plant, quite hardy, adapted to both sun and shade.

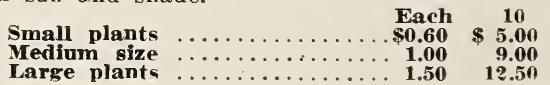




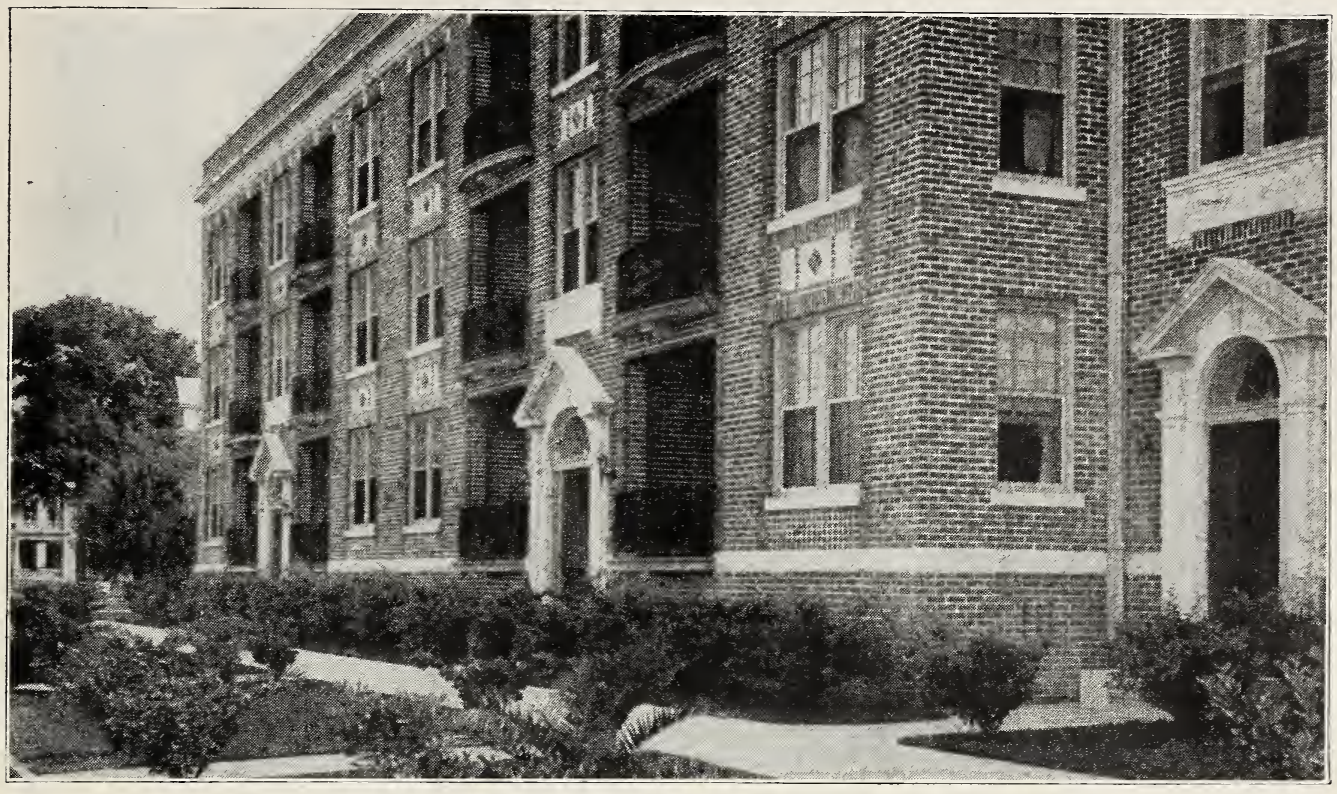

\section{Apartments and Hotels}

Recent years have brought about a change of living and particularly can we note the great number of people selecting apartments or hotels for their homes. This brings a need in the way of encouraging our hotel and apartment house own ers to take an interest in the exterior appearance of these places. Besides, there is some satisfaction derived in feeling you have made the premises as home-like as possible. Please note the picture above of a Jacksonville apartment house. The owner of this fine property claims that this planting added considerably to its value. Think of the pride the occupants feel in living in an atmosphere that is cheerful.

write us for prices and plan of arrangement. It will pay you well in the end.

\section{Business Houses}

It has often been said that big corporations and large business concerns were not interested in any beautification plan. The photo shown below refutes this statement, as this is just one example of many business buildings planted with handsolne flowering shrubs and palms. Think of the effect this nas on the passerby and how it may influence him in choosing your establishment to trade with. Then, another strong factor is the pleasing effect it has on those in your em. ploy, assuring you their best services. The whole immediate surroundings profit from silch a plant. ing and in time will become so contagious that others will follow in your welfare work. we suggest starting with a few well chosen plants ox palms. You will soon appreciate its tremendous value.

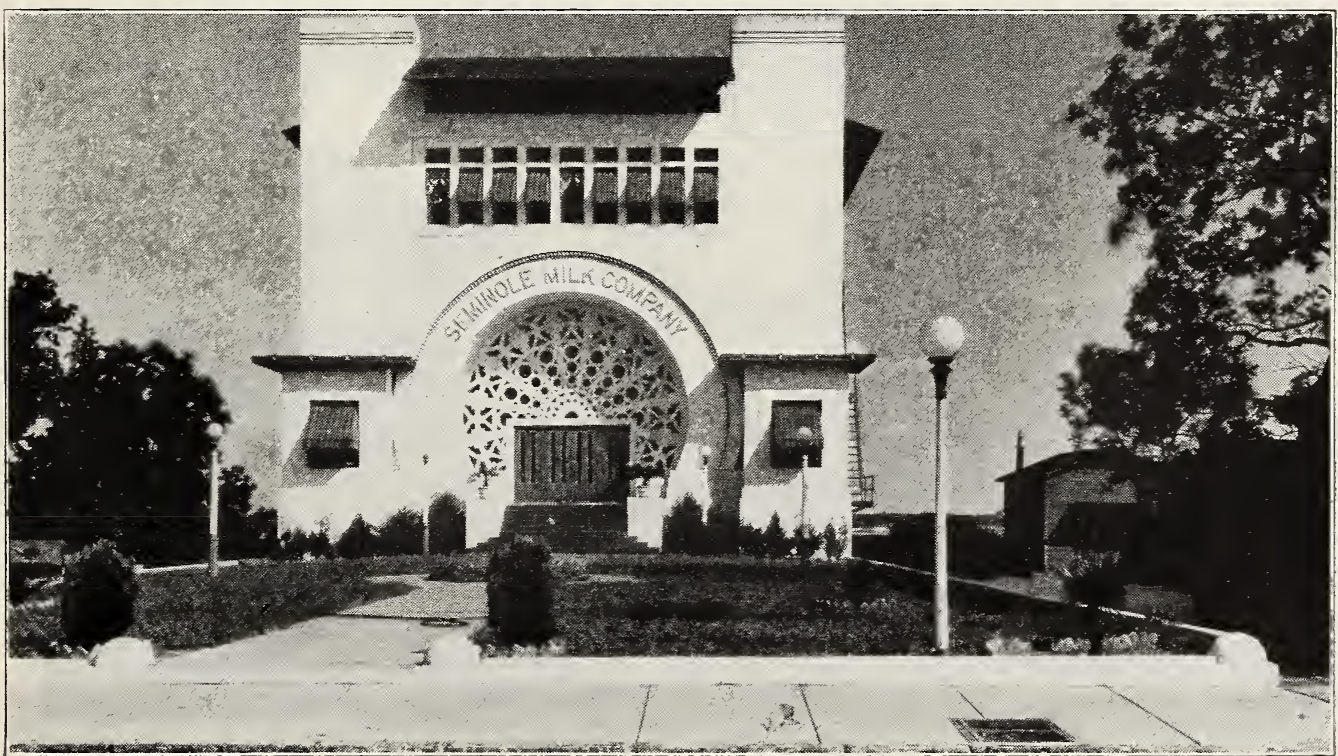




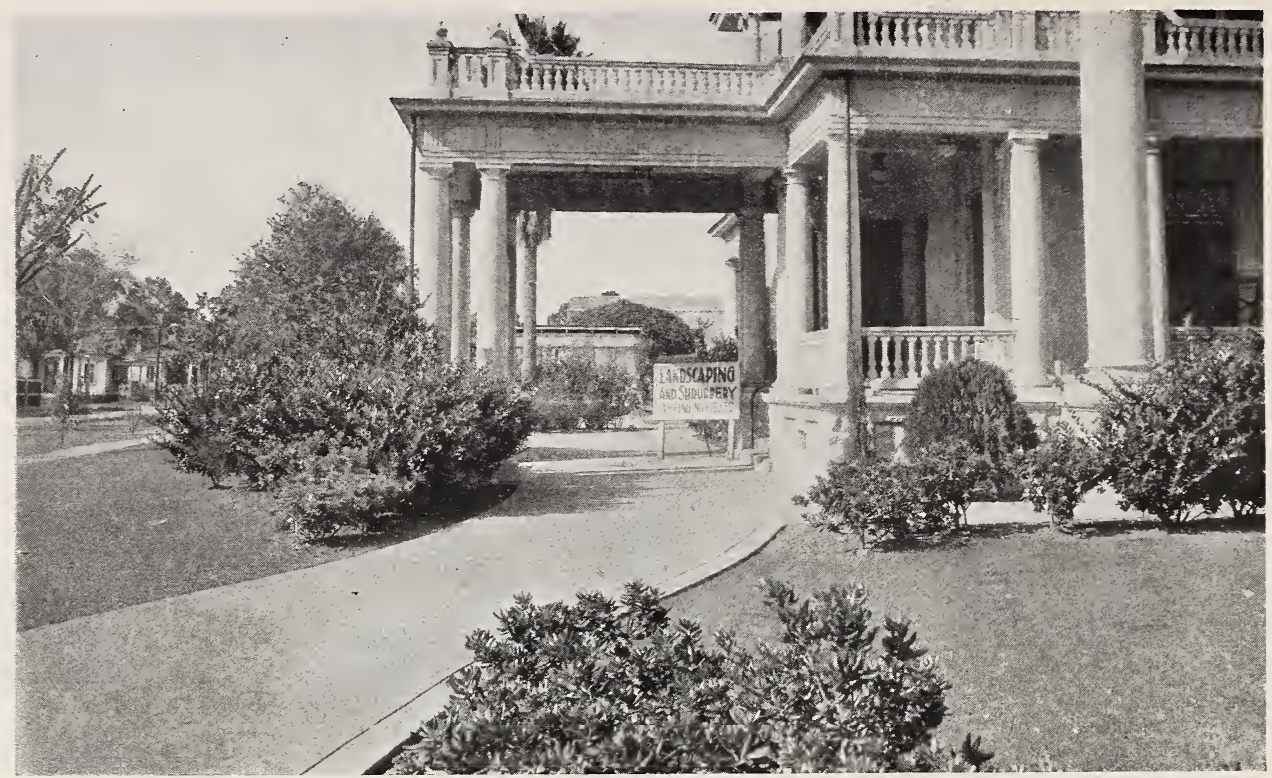

A Planting of Large Specimens, Mostly Ligustrums, Pittosporum and Conifers.

\section{Advisory Department}

Valuable Information for Those Who Are Interested in Home Grounds and Orchards

GIFFING'S Letter Aid Service is offered to all our friends. Through $\checkmark$ it we are enabled to give much the same information as is rendered through a personal call. If there are specific questions you want answered and problems you need horticultural advice about, write us in full detail and we will advise and give information without charge.

The purpose of this book is to create a desire in the hearts of southern people to take advantage of the possibilities they have within their grasp to make OUR SOUTHLAND A REAL PLACE OF BEAUTY.

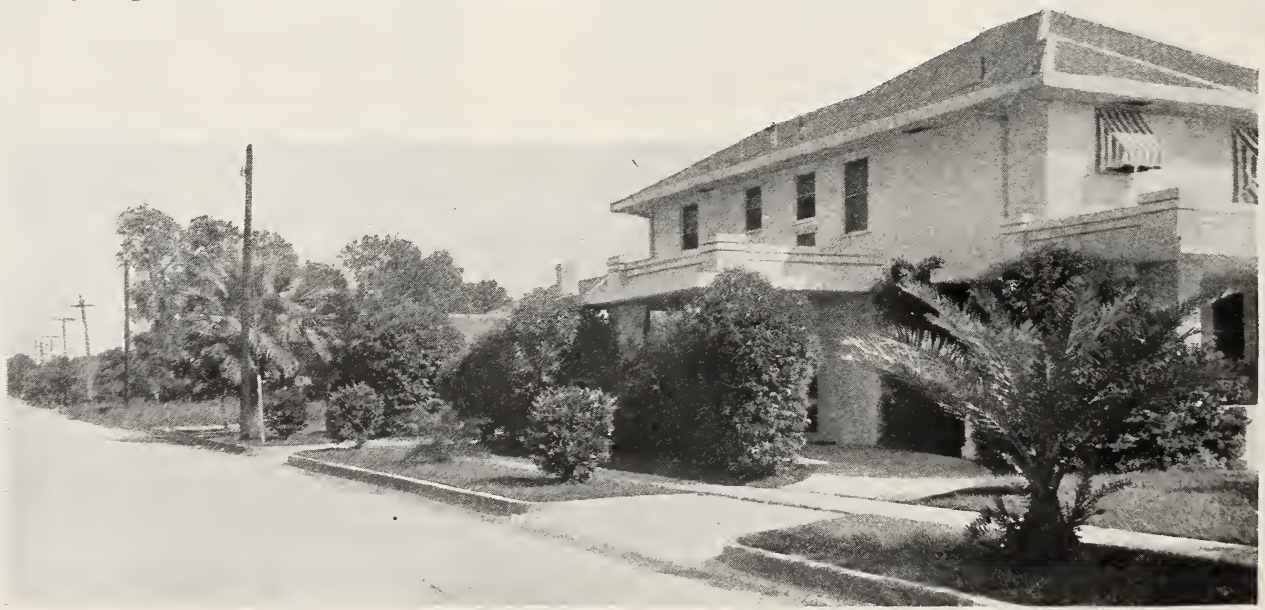

Drive Screened With Ligustrums. 


\section{Planting Instructions}

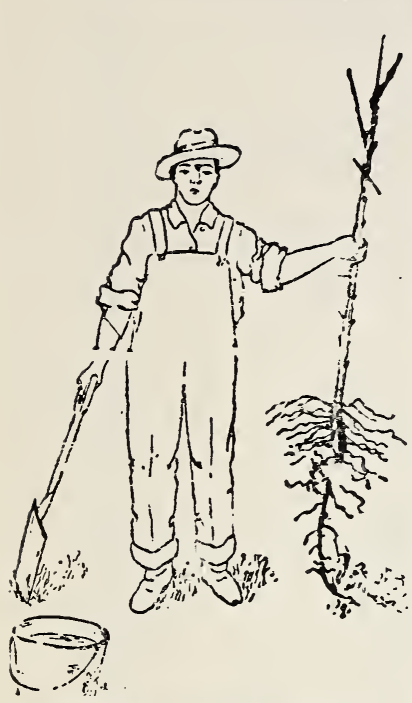

Spade and Bucket of Wate Keady to Plant a Good Tree.

Many of our customers not realize the importance of giving trees a little care upon arrival. Keep the instructions given be-
low in mind.

Failure to get satisfactory results in planting trees received from the Nursery can be largely avoided if a few simple rules for pruning and planting are observed. In most cases, failure may be traced to a lack of knowledge of the care of trees upon arrival, proper pruning and planting. On arrival of the trees from the Nursery, if unabie to plant immediately, and if the trees are dug without a ball of earth intact (balled and burlapped) they should be taken from the bale or box at once, counted and the individual tree examined. should there be a shortage, an undergrade or an unauthorized substitution, it to the general offices im to the general offices implants should immediately be heeled in a well drained. moist piece of sandy ground, in order that the soil may thoroughly pulverize between the roots. feet. Water freely and frequently, until the trees are planted.

If the trees are balled and burlapped, take from the crates or other containers as soon as received, set thein in a shady place, and cover the balls with earth or wet straw or itter.

In Orchard Planting, the ground should be thoroughly roken, pulverized, harrowed, leveled, surveyed, or laid off with a sniall stake standing where each tree is to be
plarted. For the home ground, or yard, the ground should be well spaded and pulverized.

Do not use unrotted stable manure or compost fertilizer when trees are planted. A few pounds of bone meal or a few shovelfuls of well-rotted stable manure can be used the bottom of the hole with good results at the time trees are planted. Best results with unrotted manure are attained by using it as a mulch, after the trees are planted. Commercial fertilizer should be used when tree planted. Commercial fertilizer should be used when trees start to bud out. It is applied by digging a trench around the tree or plant, a few inches past the end of the newly
fertilizer.

PRUNING ROOTS AND TOPS. All broken and mutilated portions of roots should be cut off, so as to Some people prefer to leave the tops unpruned, until the tops unpruned in order that the particn order that the particular buds they want to grow might not get broken off while planting. Severe pruning is advised, and in most instances, one-third of the tops should be removed. In some cases, it is absolutely necessary to prune and this is therefore done before the trees leave the nursery. Some of the stock which we consider absolutely necessary to prune before shipping, are Roses, Citrus Stock, and some Broad-leaf Evergreen Trees, i. e., when these are handled barerooted. You should. under no circumstances, wait several days after trees are planted to prune, as the top left is exhausting

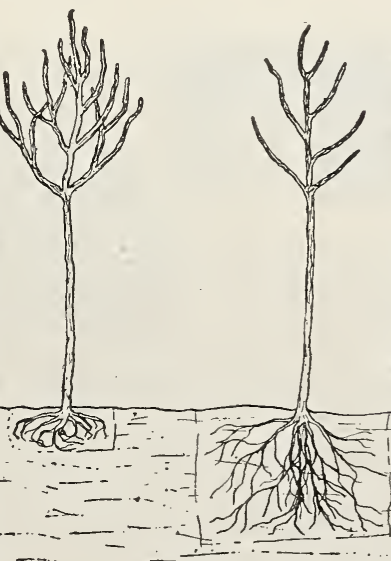

Improperly
Pruned and
Planted. $\quad \begin{gathered}\text { Properly } \\ \text { Planted }\end{gathered}$ the body and roots of the trees. Special, illustrated, and detail instructions for planting and pruning given in Griffing's Service Bulletin No. 51.

FLANTING THE TREES. We recommend using a planting board about one by four inches, six feet long. Cut a notch one inch square in the center of the beard, then bore a two-inch auger hole in each end of the board, using a round stake about one foot long, in these holes. Then the trec lift one end of the planting board off the round stake, take away the iree stake, dig your hole large enough for the tree roots to spread out without cramping roots to spread out without cramping the open hole over the round stake, and take your tree in one hand, holding it in the notch on the board and holding the in the notch on the board and holding the board (to prevent planting too deep). board (to prevent planting too deep) spread out the roots in their natural position with the other in and worked around the roots after which pour in from one to three buckets of wather, according to the size whether the ground is moist or not; it pulverizes the lumps and settles the soil around the roots more thor oughly than through any other method. If trees are planted in coarse, sticky, clay soil, it is advisable to use some sand or top are planted. After the water has soaked away, place from two to four inches of soil above the level of the land and tramp it down

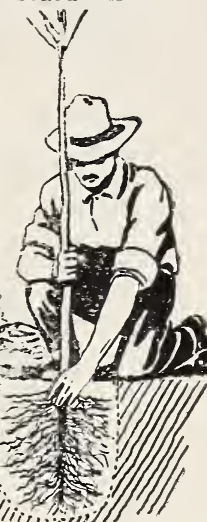

Don't be Afraid of Clothes. the better for the trees. After the earth is thoroughly packed around the trees, mulch with manure, grass or jitter. to a depth of from three to five inches.
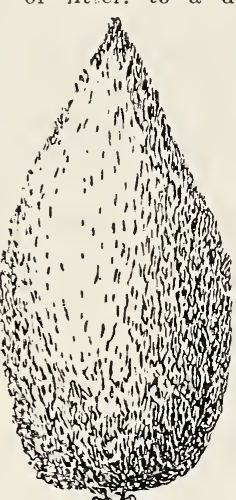

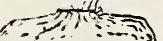

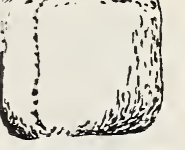

Balled and Burlapped Tree. PLANTING BALLED AND BUR-
LAPPED TREES, AND TREES THAT HAVE BEEN GROWN IN POTS. Dig the holes large and deep enough to amit the ball of earth held in place by the burlap or other wrapping, so that eneral level of the surface is even with the top of the ball, without disturbing or removing the burlap, as it will decay in moist earth by the time he roots are ready to penetrate it. Du not crumble or disturb the earth in the ball. After this is done, fill in rich moist, well-pulverized earth around the ball, water freely and pack firmly; rake loose earth around the tree and mulch

PROTECTING THE TREES. If trees are planted near the walks or drives or where cattle are likely to rub them, get thoroughly established.

SHAPING THE TREES. When the new growth starts, there should be from three to fue limbs allowed to grow, on most fruit trees, keeping the After these new branches have After these new branches have grown the from on to the ends should be pinched off and forced to branch again. This should be done several times during the first summer and the results will be-the trees will have pretty uniform shapes. trergreen trees and shrubs should be copd hound and
CULTIVATION. Uept headed back frequently. ecommended, the soil should be kept loosened up around newiy planted trees from two to three inches deep, about three or four times during the first summer, either by means of a cultivator or by hand. Surface drainage should always be thorough and a basin or water puddle should never be allowed to form about the trees.

INSECTS AND DISEASES. No plant exists that doe not, in some manner, furnish food for something else Hence, all trees, plants, etc., are subject to attacks from insects and fungi.

Don't neglect your trees by planting crops, flowers, etc. near them.

Bon't drive over them and let stock eat them and break ihem down. (In some cases, people want us to replace the stock when this happens)

QUESTIONS As to future care and management of trees, receipts for spraying, etc., not covered on this page will be answered for our customers to the best of ou ability. 


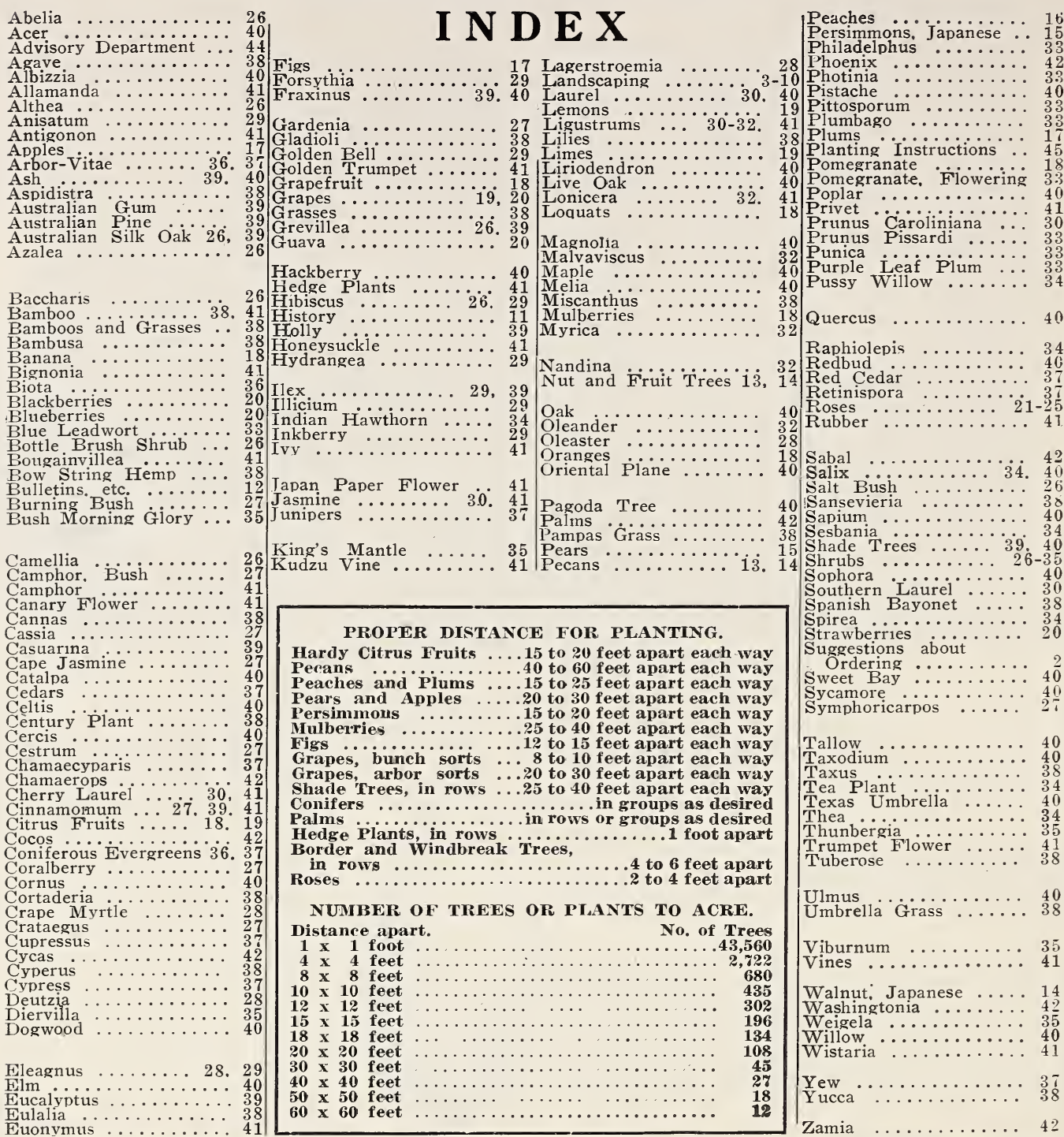

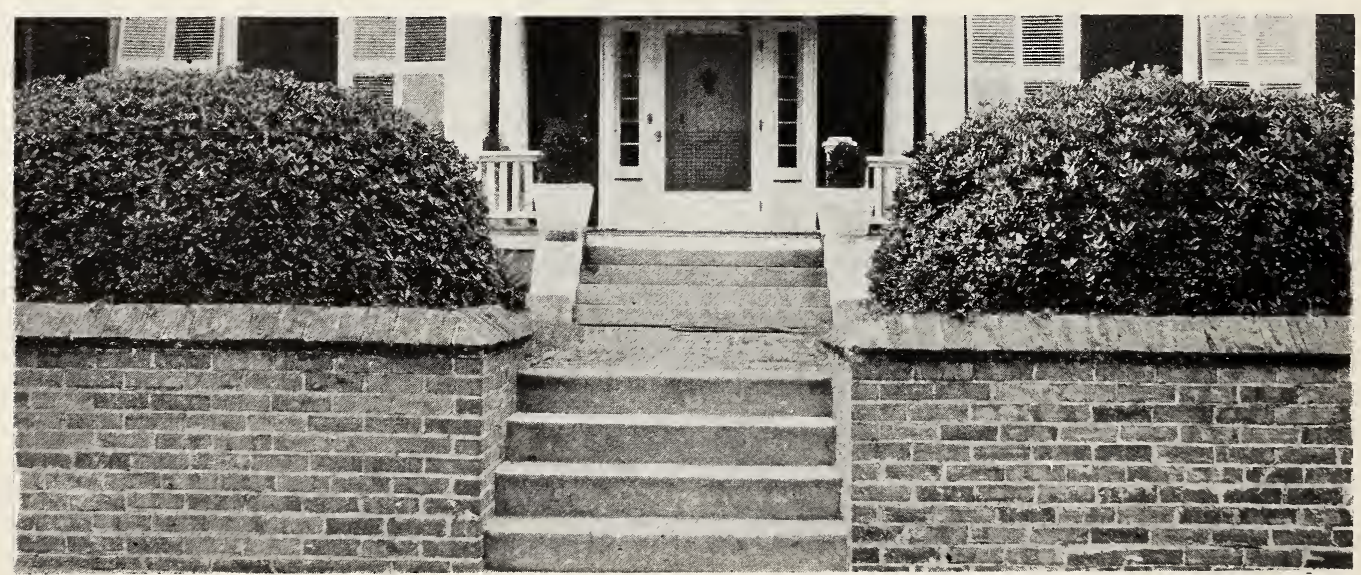

Pittosporum. 


\section{OUR PATRONS WILL OBHGE US BY USING THIS ORDER SHEET. \\ READ TERMS OF SALE, PAGE 2 . \\ Griffing's Interstate Nurseries \\ Jacksonville, Fla.}

For amount enclosed, $\$$

Send me on

(Specify about date wanted).

By the Trees and Plants designated below.

(Write here "Freight," "Express," or "Use your Discretion.")

Name $\quad\left\{\begin{array}{l}\text { Mrs. } \\ \text { Mr. } \\ \text { Miss }\end{array}\right\}$

Street and Number

Post Office

State

Express or Freight Office

We substitnte unless instructed to the contrary, but never until the varieties ordered are exhausted. If you do not want us to substitute in case we are out of the varieties or sizes, write the word "NO" here in which case we will refund for shortage.

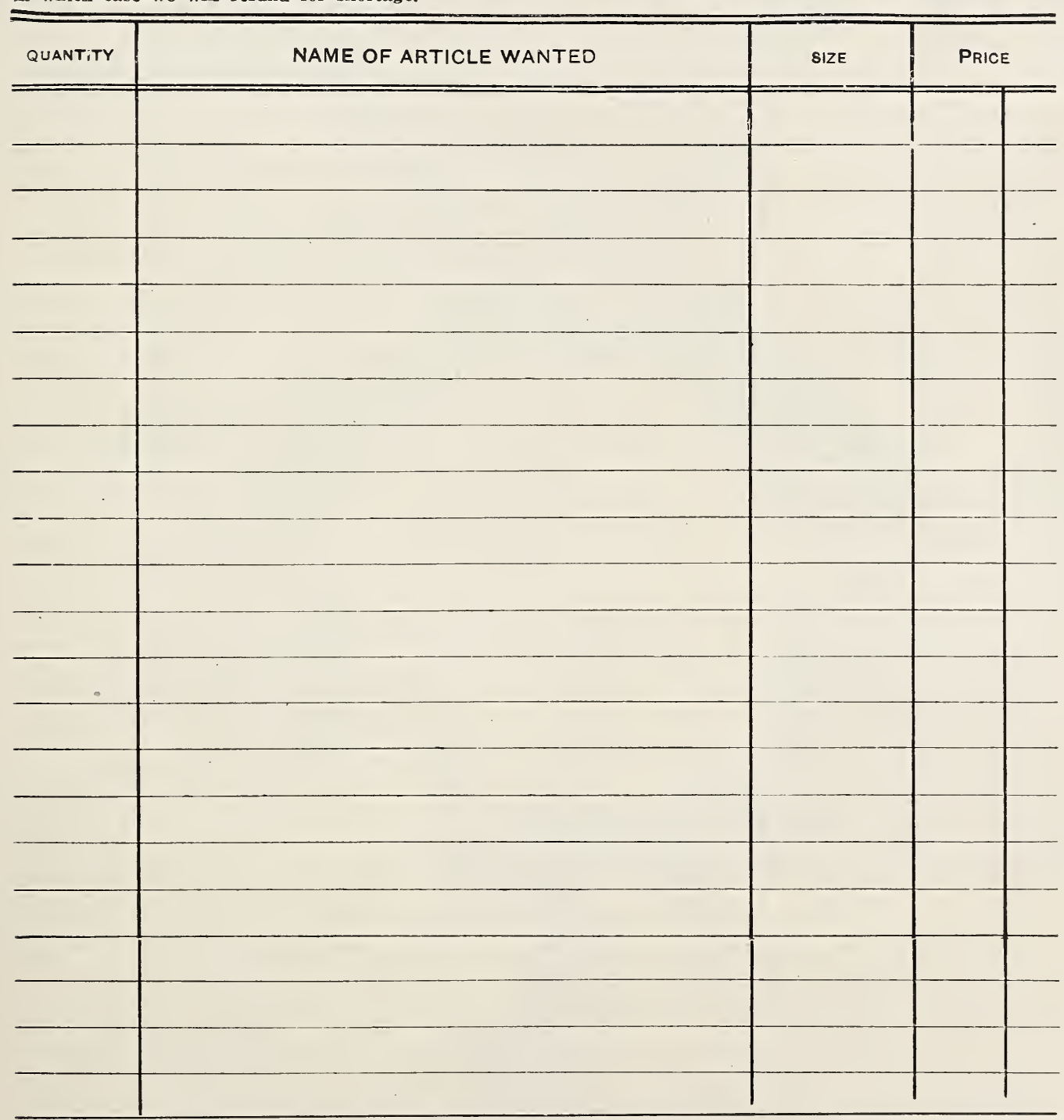


Order Sheet Continued.

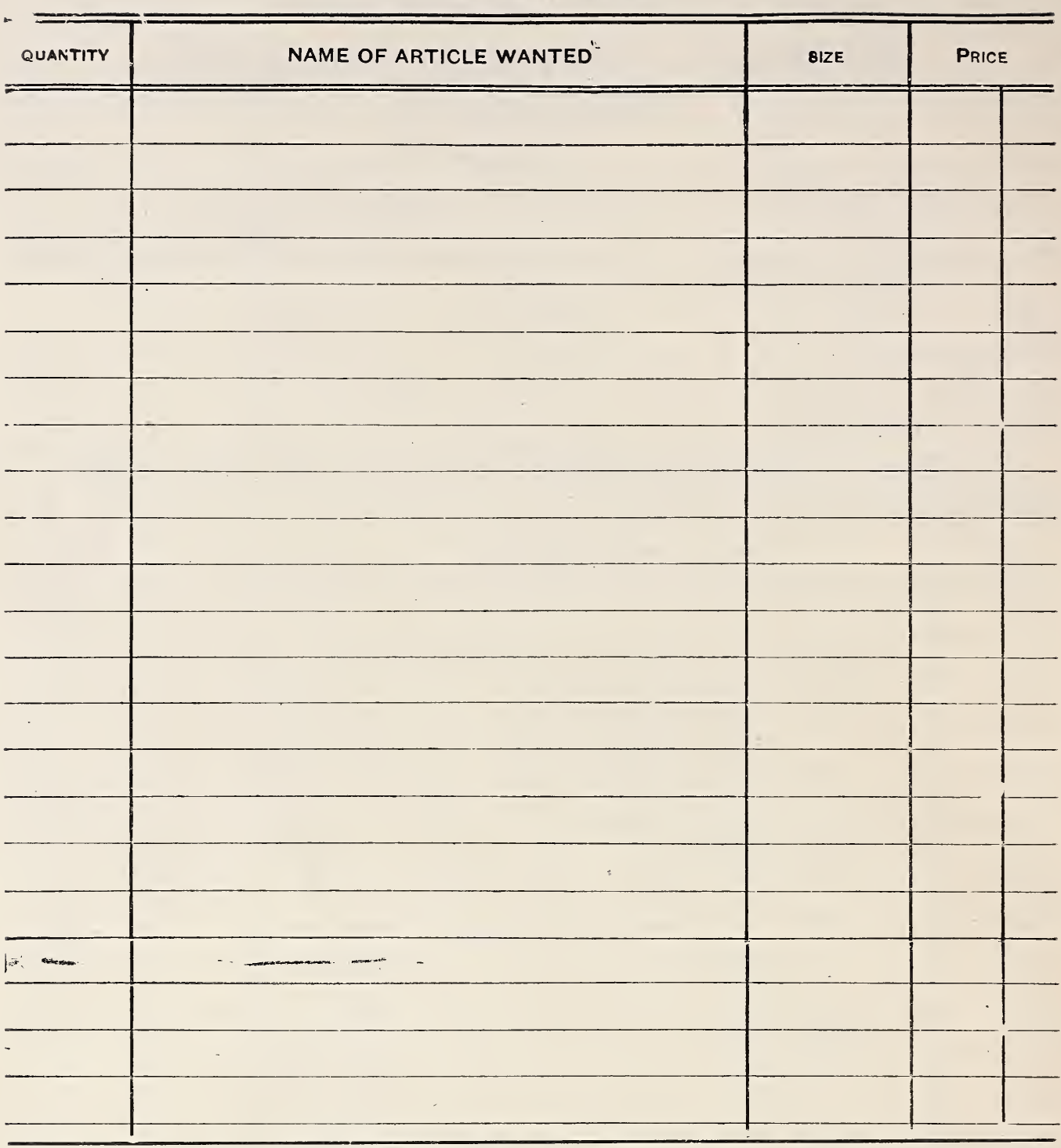

If you have friends or neighbors you believe will be interested in our catalog please write their names below. Thank you.

\begin{tabular}{l|c|c|c|c}
\hline NAME & R. F. D. or Street Number & & TOWN & \\
\hline & & & & \\
\hline & & & & \\
\hline
\end{tabular}




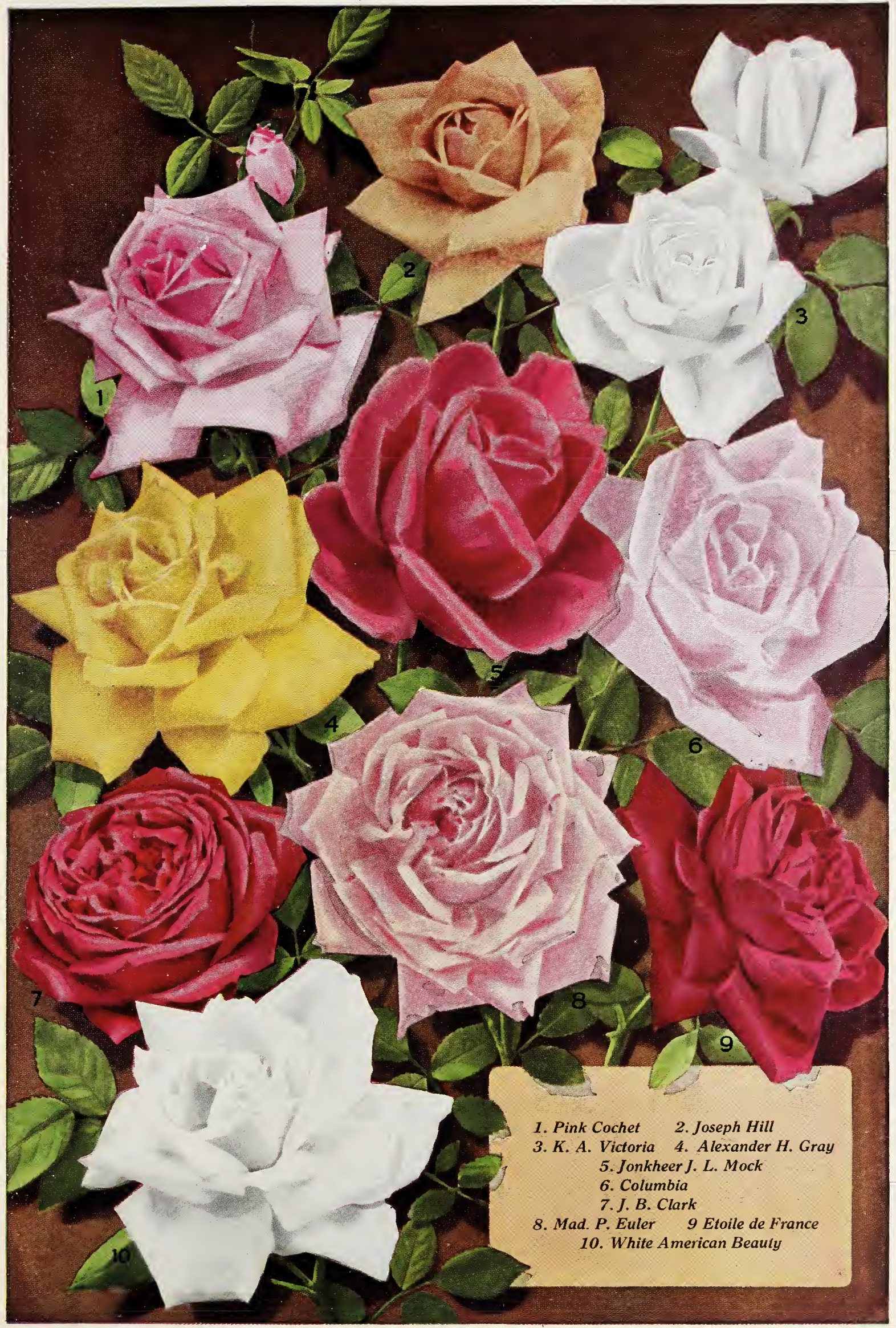




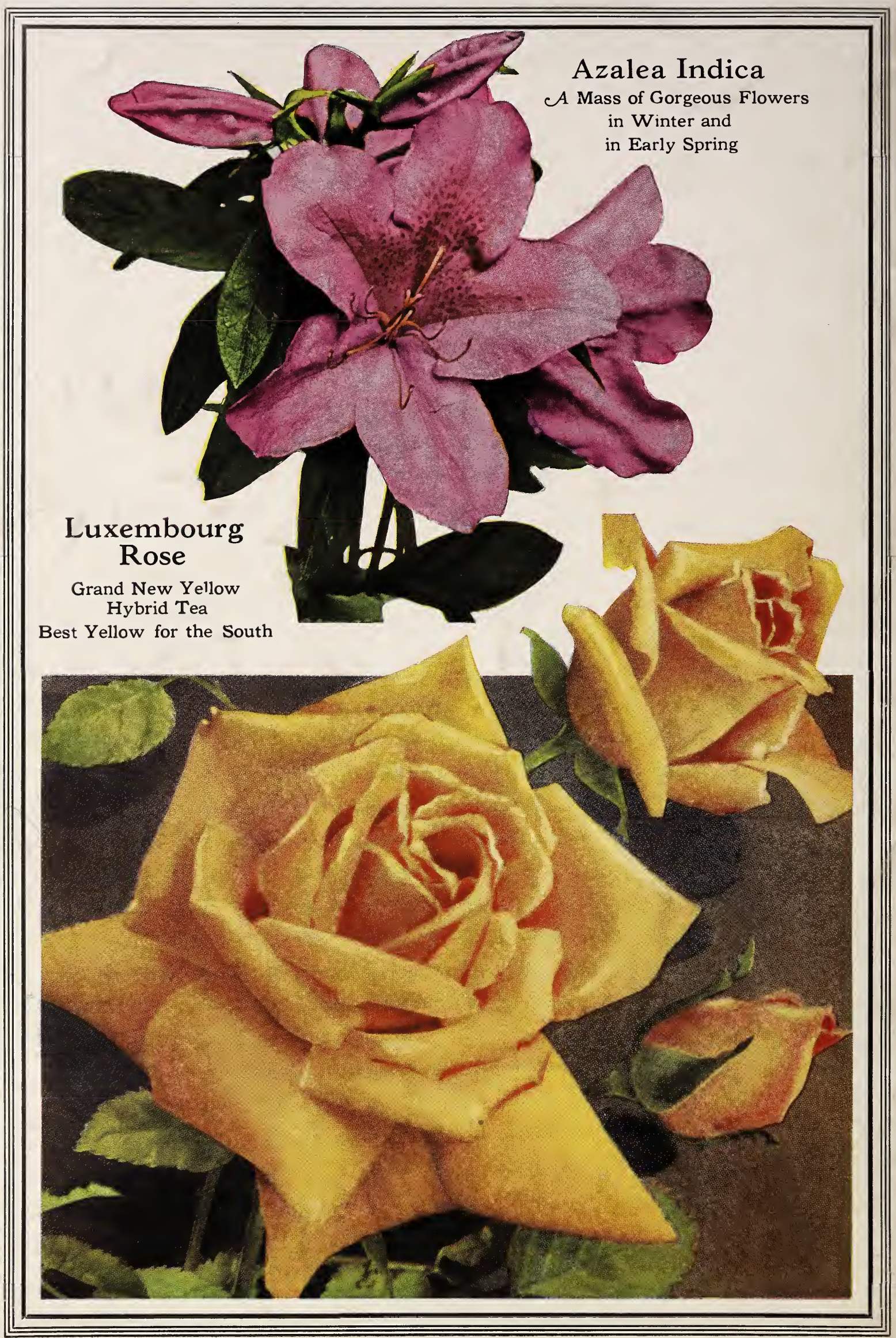

